\title{
A CASE STUDY EVALUATING RUNOFF GENERATION IN A SUBARCTIC CATCHMENT USING S'TABLE ISO'TOPE, HYDROCHEMICAL AND HYDROMETRIC DATA
}

\author{
by \\ Jessica Lynch Boucher \\ A thesis submitted to \\ The Faculty of Graduate Studies and Research \\ In partial fulfillment of the requirements of the degree of \\ Master of Science \\ Department of Geography and Environmental Studies \\ Carleton University \\ Ottawa, Ontario \\ September 2009 \\ (C) Jessica Lynch Boucher
}




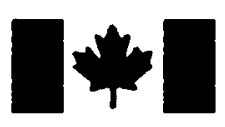

Library and Archives Canada

Published Heritage
Branch

395 Wellington Street

Ottawa ON K1A ON4

Canada
Bibliotheque et

Archives Canada

Direction du

Patrimoine de l'édition

395, rue Wellington

Ottawa ON K1A ON4

Canada
Your file Votre refférence

ISBN: 978-0-494-60197-6

Our file Notre référence

ISBN: 978-0-494-60197-6
NOTICE:

The author has granted a nonexclusive license allowing Library and Archives Canada to reproduce, publish, archive, preserve, conserve, communicate to the public by telecommunication or on the Internet, loan, distribute and sell theses worldwide, for commercial or noncommercial purposes, in microform, paper, electronic and/or any other formats.

The author retains copyright ownership and moral rights in this thesis. Neither the thesis nor substantial extracts from it may be printed or otherwise reproduced without the author's permission.
AVIS:

L'auteur a accordé une licence non exclusive permettant à la Bibliothèque et Archives Canada de reproduire, publier, archiver, sauvegarder, conserver, transmettre au public par télécommunication ou par l'Internet, prêter, distribuer et vendre des thèses partout dans le monde, à des fins commerciales ou autres, sur support microforme, papier, électronique et/ou autres formats.

L'auteur conserve la propriété du droit d'auteur et des droits moraux qui protège cette thèse. $\mathrm{Ni}$ la thèse ni des extraits substantiels de celle-ci ne doivent être imprimés ou autrement reproduits sans son autorisation.
In compliance with the Canadian Privacy Act some supporting forms may have been removed from this thesis.

While these forms may be included in the document page count, their removal does not represent any loss of content from the thesis.
Conformément à la loi canadienne sur la protection de la vie privée, quelques formulaires secondaires ont été enlevés de cette thèse.

Bien que ces formulaires aient inclus dans la pagination, il n'y aura aucun contenu manquant.

\section{Canada}




\begin{abstract}
Hydrometric, isotopic and hydrochemical data were used to investigate runoff generation in a discontinuous permafrost headwater catchment. Research was undertaken between 10 April and 8 July, 2008 within Granger Basin, a $7.6 \mathrm{~km}^{2}$ sub-catchment of the Wolf Creek Research Basin, Yukon Territory, Canada. The main objectives of this research were to determine: i) the main components of the water balance and their values throughout the snowmelt period; ii) the role of aufeis and channel ice on streamflow quantity and quality and iii) the magnitude and timing of runoff components during the spring melt period. The main components of the water balance in Granger Basin were snowmelt (152 mm), precipitation $(68 \mathrm{~mm})$, evaporation $(88 \mathrm{~mm})$, discharge $(173 \mathrm{~mm})$ and change in storage $(-41$ $\mathrm{mm})$. Aufeis and channel ice represented less than $1 \%$ of total streamflow, however, they did alter streamflow pathways and the timing of discharge. Pre-event water represented $\sim 73$ $\%$ of total streamflow during the snowmelt period. End-member mixing analysis enabled the determination of three contributing end-members to streamflow. Initially, the groundwater end-member dominated streamflow, followed by soil water end-member, the snowmelt water and then back toward the groundwater end-member chemistry. Concentration versus discharge plots elucidated the dilution of weathering ions by snowmelt water and the chemostatic behaviour of ions that originated in organic soils. The potassium to calcium ratio (K:Ca) of streamwater indicated an early contribution of pre-event soil water during snowmelt generation. The combined use of hydrometric, isotopic and hydrochemical data demonstrated the importance and timing of the pre-event soil water contribution to snowmelt runoff generation in Granger Basin. These insights advance our knowledge and understanding of runoff generation in Granger Basin and demonstrate the value of a mixed methods approach to tracer based investigations.
\end{abstract}




\section{ACKNOWLEDGEMENTS}

I wish to thank my supervisor Dr. Sean K. Carey for his guidance, support, flexibility and patience as well as for the many invaluable opportunities he has provided me with over the last two years.

I would like to express many thanks to everyone who helped me in the field: Ashley Graham, Mike Treberg, Shawn MacDonald, Cecile Menard and Qian Che.

Many thanks to Ric Janowicz, Glenn Ford, Glen Carpenter and Jocelyn Joe-Strack at the Water Resources Branch, Yukon Government. A special thanks to Cathy Ford, Jenny Ford and Leslie Gomm for their support in Whitehorse.

Thank you to Richard Essery at the University of Edinburgh for securing a workspace for me during the 2008-2009 academic year.

Sean Goodbrand and Yinsuo Zhang provided support at Carleton University and I am thankful for their input, advice and patience.

To my friends and family - Robbie Davidson, Margo Davidson, Mom Boucher, Dad Boucher, Emma-Leigh Boucher and Jared Young - thank you for your love and support. 


\section{TABLE OF CONTENTS}

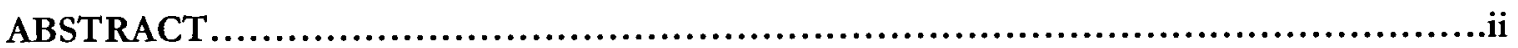

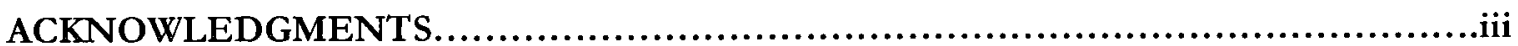

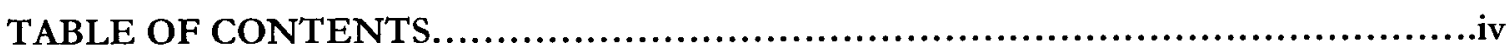

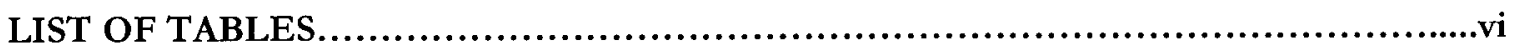

LIST OF FIGURES..................................................................

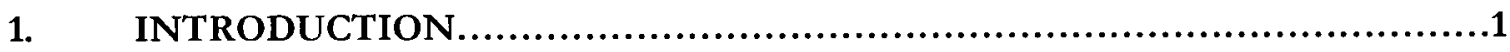

$1.1 \quad$ Research Objectives........................................................

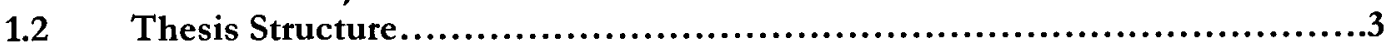

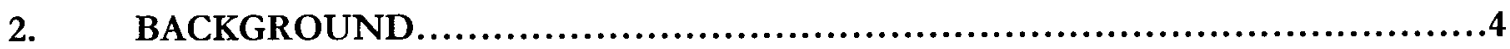

$2.1 \quad$ General Context...............................................................

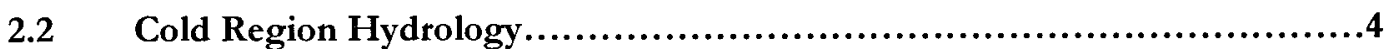

2.2.1 Runoff Generation

2.2.2 Aufeis and Channel Ice

Water Balance.................................................................

Isotope and Ion Tracers......................................................

2.4.1 Stable Isotopes

2.4.2 Major Ions

$2.5 \quad$ Hydrograph Separation.....................................................22

2.6 End-Member Mixing Analysis..........................................28

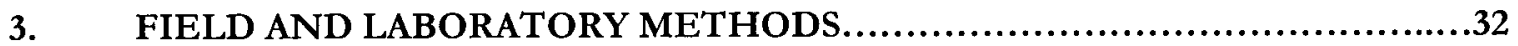

3.1 Site Description.........................................................

3.1.1 Climate

3.1.2 Geology

3.1.3 Ecology

3.1.4 Hydrology

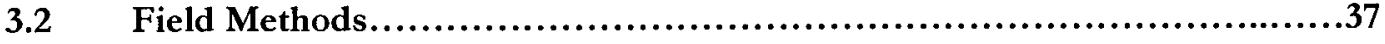

3.2.1 Discharge monitoring

3.2.2 Meteorological monitoring stations

3.2.3 Water quality parameters

3.2.4 Water sampling

3.2.5 Snow surveys

3.2.6 Aufeis and Channel Ice

3.2.7 Soil Moisture

3.2.7 Time lapse photography

3.3 Laboratory Methods.

3.3.1 Stable isotope analysis

3.3.2 Major ion analysis

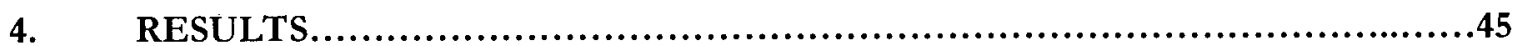

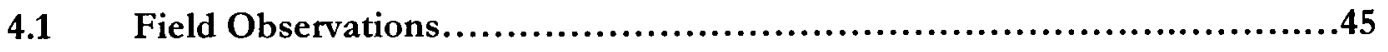

4.1.1 Climate

4.1.2 Discharge

4.1.3 Snow 
W.2 Water Balance..............................................................51

$4.3 \quad$ Hydrograph Separations................................................54

$$
\text { 4.3.1 Uncertainty Analysis }
$$

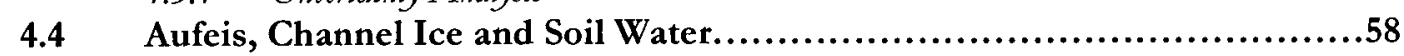

4.5 End-Member Mixing Analysis...........................................60

4.6 Isotopic Observations....................................................63

4.7 Hydrochemical Observations..........................................65

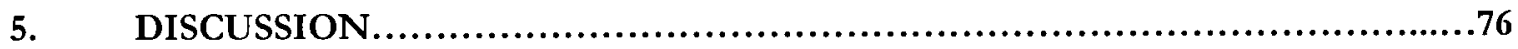

$5.1 \quad$ Water Balance...............................................................

5.2 Runoff Generation..................................................... 78

5.2.1 Hydrograph Separation

5.2.2 End-member Mixing Analysis

5.2.3 Isotopic Observations

5.2.4 Hydrochemical Observation

5.2.5 Summary

$5.3 \quad$ Sources of Error............................................................

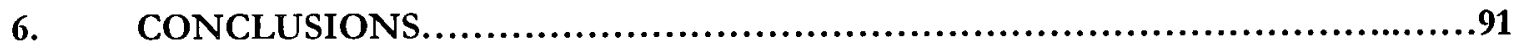

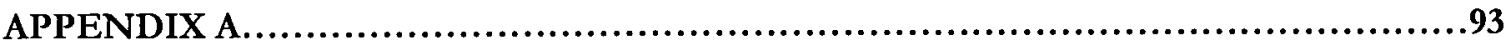

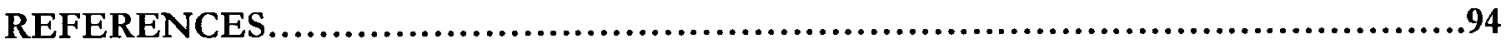




\section{LIST OF TABLES}

Table

2.1 Diagnostic features used by Evans and Davies (1998).

2.2 Summary of the findings of a number of studies using tracers to separate streamflow into pre-event and event water.

4.1 Total amount of snowmelt from each of the three contributing areas and the percent of snowmelt input this represents.

4.2 Granger Basin outlet water balance components and runoff ratio.

4.3 Pre-event and event water $\delta^{18} \mathrm{O}$ and $\delta^{2} \mathrm{H}$ values \pm standard error.

4.4 Amount of pre-event and event water in both percent and water equivalent based on both $\delta^{18} \mathrm{O}$ and $\delta^{2} \mathrm{H}$.

4.5 Analytical and standard error values for pre-event, event and streamwater components.

4.6 The maximum and minimum length, width, depth, volume and water equivalent of the aufeis feature.

4.7 Total volume and water equivalent of basin-wide ice melt water, snowmelt water, soil water and stream water.

4.8 End-member values for $\delta^{18} \mathrm{O}, \delta^{2} \mathrm{H}$ and chloride \pm standard error.

4.9 Ion concentrations of end-member components $( \pm$ standard error) and high and low values for both the outlet and Location B.

4.10 Diagnostic features used by Evans and Davies (1998).

4.11 Potassium to calcium (K:Ca) ratios for ice, snow, groundwater and soil. 


\section{LIST OF FIGURES}

$\begin{array}{lll}\text { Figure Page } & \text { Pag }\end{array}$

2.1 The $\delta^{18} \mathrm{O}-\delta^{2} \mathrm{H}$ correlation for global precipitation plotted from data $\mathbf{1 5}$ on the International Atomoic Energy Agency GNIP database (Clark, 2008).

2.2 Conceptual drawing of the change in ${ }^{18} \mathrm{O}$ content of precipitation according to a Rayleigh distillation (Clark, 2008).

2.3 Conceptual representation of concentration-discharge plots modified from Evans \& Davies (1998).

2.4 Conceptual drawing of end-member mixing.

2.5 Example of an end-member mixing diagram.

3.1 Study area map indicating (a) Whitehorse within North America, (b) Whitehorse within the Yukon and (c) the Wolf Creek Research Basin relative to Whitehorse.

3.2 Map of Granger Basin.

3.3 Permafrost zones in Yukon Territory and relative location of the Wolf Creek Research Basin (Lewkowicz and Ednie, 2004).

3.4 Yukon terrestrial ecozones and ecoregions with study area indicated in black.

3.5 Study area map indicating snow transects, water sampling sites, discharge monitoring sites, aufeis, ice core locations, time lapse photography tripod and the location of the headwater and outlet meteorological towers. Map not to scale.

4.1 (a) Mean daily air temperature, (b) daily net radiation, and (c) total precipitation.

4.2 Granger Basin hydrograph throughout the snowmelt period.

4.3 (a) Snow water equivalent (SWE), and (b) snow covered area (SCA) for all 8 snow transects.

4.4 Average snowmelt rates for (a) Contributing Area 1 (black), (b) Contributing Area 2 (grey) and (c) Contributing Area 3 (dark grey). 
4.5 Area weighted average snowmelt rate for the entire Granger Basin Catchment.

4.6 Granger Basin daily evapotranspiration. $\quad 53$

4.7 Cumulative daily water balance components. 53

4.8 Isotope hydrograph separations using (a) $\delta^{2} \mathrm{H}$ and (b) $\delta^{18} \mathrm{O}$. 54

4.9 Hydrograph separation results for (a) $\delta^{18} \mathrm{O}$ and (b) $\delta^{2} \mathrm{H}$ as the event $\mathbf{5 5}$ water fraction $(\%)$ of total discharge.

4.10 Aufeis ablation curve depicting the percent volume remaining over time.

4.11 Snow, ice and groundwater end-member mixing diagrams for (a) chloride vs. $\delta^{18} \mathrm{O}$ and (b) chloride vs. $\delta^{2} \mathrm{H}$ ( \pm standard error). Arrows indicate the direction of streamflow evolution ( 1 being the start and 4 being the end).

4.12 Snow, soil and groundwater end-member mixing diagrams for (a) chloride vs. $\delta^{18} \mathrm{O}$ and (b) chloride vs. $\delta^{2} \mathrm{H}$ ( \pm standard error). Arrows indicate the direction of streamflow evolution (1 being the start and 4 being the end).

4.13 Local meteoric water line for the Whitehorse area. Outlet, Location

$B$ and Location $C$ streamwater values are also plotted in red, green and blue, respectively.

4.14 Time series of (a) $\delta^{18} \mathrm{O}$ and (b) $\delta^{2} \mathrm{H}$ observed at Location $\mathrm{B}$ (red points), and Location $C$ (green points) and the outlet (blue line).

4.15 Time series of SpC measured at the outlet (blue) and Location B $\mathbf{6 6}$ (red).

4.16 Time-series of major ions measured at (a) the outlet and (b) Location B.

4.17 Mass flux of all solutes measured at the basin outlet throughout the study period.

4.18 Concentration versus discharge plots for all solutes during the study period. Arrows indicate the direction of the hysteresis loops.

4.19 Concentration-discharge relationships for all solutes and $\mathrm{SpC}$.

4.20 Hydrograph (black) and K:Ca ratio over time (blue) measured at the basin outlet. 


\section{INTRODUCTION}

The processes and mechanisms that control runoff generation in northern environments have long been subject to inquiry, yet our lack of field-based research capacity in remote northern regions results in continued scientific uncertainty in this field. The ability to accurately predict streamflow is important for land use planning, flood forecasting, dam construction, watershed modeling, contaminant transport, infrastructure engineering, and erosion and slope stability studies. In addition, a better understanding of stream chemistry and runoff generation is needed in order to improve policy and management of a vast number of pollutants. It is for these reasons, and many others, that the field study of streamflow generation processes remains a significant topic in hydrology today.

Hydrological processes in northern latitudes are extremely complex and spatially variable (Uhlenbrook and Hoeg, 2003). The principles and concepts that have previously been developed for temperate environments are often modified and used in cold regions which, unlike temperate regions, are dominated by snow and ice melt processes. Snowmelt is considered the most important hydrological and hydrochemical event in Arctic and Subarctic watersheds due to the fact that it transfers approximately half of the annual precipitation to the stream during the snowmelt period (Woo, 1986). It is important to understand how water is distributed, moved, stored and influenced by the unique physical and chemical features of northern ecosystems in order to make effective predictions concerning the future of this rapidly changing environment.

The chemical and isotopic properties of water provide a unique opportunity to study the source areas of runoff, flow pathways, residence times, reservoir volumes and hydraulic 
characteristics of flow systems. The use of isotope and chemical data is extremely useful due to the fact that: (i) stable isotopes do not participate in chemical reactions thus providing key information concerning original source areas; and (ii) dissolved solutes do participate in chemical reactions thus providing critical information concerning flow pathways (Hooper and Shoemaker, 1986; Maule and Stein, 1990).

This research examines the role of runoff components on streamflow hydrology and hydrochemistry within Granger Basin $\left(7.6 \mathrm{~km}^{2}\right)$, a discontinuous permafrost headwater watershed located within the larger Wolf Creek Research Basin $\left(195 \mathrm{~km}^{2}\right)$, Yukon Territory, Canada. This study is unique in that while other studies have used similar techniques, this study is the first to combine comprehensive hydrometric, hydrochemical and isotope sampling and analyses to evaluate snowmelt runoff components in Granger Basin.

One of the goals of this research is to improve understanding of the role of channel ice and aufeis on streamflow generation in this particular Subarctic headwater catchment. During the spring melt period, extensive flooding and damage to engineered structures occurs due to channel ice and aufeis ablation. The current rate of development in the North is creating a real need for knowledge concerning the distribution of ice and its role in northern watershed hydrology. 


\subsection{Research Objectives}

This research employs the use of hydrometric, isotopic and hydrochemical data to examine runoff generation. The specific research questions of this thesis are:

i) What are the main components of the water balance and their values throughout the snowmelt period?

ii) What, if any, is the role of aufeis and channel ice on streamflow quantity and quality?

iii) What is the magnitude and timing of runoff components during the spring melt period?

These questions are addressed using a variety of techniques including isotope and ion chemistry, end-member mixing analyses and two-component isotope hydrograph separations. This research will help to improve our knowledge and understanding of runoff generation processes in this region.

\subsection{Thesis Structure}

Six chapters form the content of this thesis. This introduction is followed by Chapter Two which examines the background theory related to cold region hydrology, water balance studies, ion and isotope tracers, hydrograph separations and end-member mixing analyses. The background chapter is followed by Chapter Three, which contains a detailed site description as well as a discussion of field and laboratory methods. Chapter Four describes the results that were obtained and Chapter Five discusses these results. The final chapter, Chapter Six, summarizes the key findings and conclusions obtained by this investigation. 


\section{BACKGROUND}

\subsection{General Context}

The presence of permafrost in northern environments influences the way in which water travels through the hydrological cycle. General circulation models (GCMs) predict increases in temperatures at high latitudes which may result in the widespread melt of permafrost in northern regions (Petrone et al., 2006). A warmer climate could also lead to a variety of other hydrological changes which could alter the contribution and timing of snowmelt water, the amount of soil water storage and could also alter runoff pathways. A thorough baseline understanding of the hydrological processes of northern environments is needed in order to help make accurate predictions concerning the impact of change in these regions.

The ability to accurately predict streamflow is also important for land use planning, flood forecasting, dam construction, watershed modeling, contaminant transport, infrastructure engineering, and erosion and slope stability studies. In addition, a better understanding of stream chemistry and runoff pathways is needed in order to improve policy and management of a vast number of pollutants. It is for these reasons, and others, that the field study of streamflow generation remains a significant topic in hydrology today.

\subsection{Cold Region Hydrology}

Hydrological processes in northern latitudes are extremely complex and spatially variable (Uhlenbrook and Hoeg, 2003). The principles and concepts that have previously been developed for temperate environments are often modified and used in cold regions which, unlike temperate regions, are dominated by snow and ice-melt processes. Snowmelt is 
considered the most important hydrological and hydrochemical event in Arctic and Subarctic watersheds due to the fact that it transfers approximately half of the annual precipitation to the stream throughout the snowmelt period (Woo, 1986; McNamara et al., 1998; Carey and Woo, 2001; Carey and Quinton, 2004; Hinzman et al., 2005; McCartney et al., 2006). It is necessary to understand how water is distributed, moved, stored and influenced by the unique physical and chemical features of northern ecosystems in order to make effective predictions concerning the future of this rapidly changing environment.

The study of cold region hydrology presents challenges to investigators due to logistical constraints, extreme environments and the unique role of permafrost on the hydrological cycle. When the ground (ice, peat, mineral soil or rock) has been held at or below $0^{\circ} \mathrm{C}$ for at least two consecutive summers it is defined as permafrost (Brown, 1974). Permafrost may be continuous, discontinuous or sporadic; the type of permafrost that is found at any given location is largely dependent upon the surface energy balance, topography, soil thermal properties, lithology and snow cover of the region (Woo, 1986; Williams and Smith, 1988; Hinzman et al., 2005). Permafrost directly and indirectly affects water quality, distribution, availability and storage and, in 1970, could be found under approximately half of Canada (Brown, 1970).

The infiltration of rainfall and snowmelt water is impeded by permafrost which limits the interactions between near-surface and sub-permafrost aquifers and greatly influences streamflow generation (Dingman, 1966; Slaughter et al., 1983; Chacho and Bredthauer, 1983; Carey and Woo, 1998, 1999; Quinton et al., 2005; Hinzman et al., 2005; Petrone et al., 2006). The soil that exists above the permafrost is termed the active layer, which is a zone that 
freezes and thaws annually (Williams and Smith, 1988). The thickness of the active layer is generally between $0.3-1.0 \mathrm{~m}$, but has been shown to vary considerably both temporally and spatially (Brown, 1970; Williams and Smith, 1988).

As a result of limited deep percolation due to permafrost, the active layer is often saturated thus facilitating the soil conditions necessary for lateral water movement to occur. When present, permafrost increases surface and near-surface runoff and reduces the baseflow contribution to streamflow (Dingman, 1966, 1971; Slaughter et al., 1983). As the fraction of permafrost declines in the discontinuous permafrost zone, the relative portion of baseflow increases since deeper subsurface water is able to travel through longer pathways to the stream (Bolton et al., 2000; Hinzman et al., 2005). Understanding the interconnectedness between permafrost and runoff generation is important as it aids in understanding the movement and cycling of water in cold regions.

\subsubsection{Runoff Generation}

Regions that are dominated by snowmelt processes experience a pronounced spring melt period and are located in a nival regime (Woo, 1990). The spring melt period can often result in severe flooding and erosion. Subarctic nival regimes are characterized by low flow during the winter, which is sustained by groundwater baseflow, followed by a high flow period during the spring, which is related to snow and ice melt processes.

The most popular runoff generation theories were summarized by Freeze (1974) as: (i) overland flow (Horton, 1933); (ii) partial area overland flow (Betson, 1964); (iii) variable source area saturation overland flow (Dunne and Black, 1970); and (iv) variable source area 
subsurface flow (U.S. Forest Service, 1961). More recently the mechanisms that generate runoff in Subarctic watersheds have been defined as: (i) overland flow; (ii) inter-tussock flow; and (iii) pipeflow or matrix flow in the near-surface soil (Carey and Woo, 2000).

There are two major controls on snowmelt runoff generation in Granger Basin that have previously been outlined by Quinton et al. (2000) and Carey and Quinton (2004): (i) permafrost distribution defines basin contributing areas as lateral flow is confined to permafrost-underlain slopes due to their ability to restrict deep percolation; and (ii) surface organic soils play a key role in rapidly conveying water to the stream due to their unique hydraulic properties. Previous work in the study area determined that during the snowmelt period, when hillslopes are wet, the water table rises and runoff may be generated from two different source areas: (i) a lower zone at the base of the slope that provides a fast response; and (ii) zones further upslope that deliver water through the saturated organic layer to the hillslope base over extended periods (Carey and Woo, 2001).

Slope aspect is also an important component of runoff generation as it causes large variations in runoff patterns due to differences in the amount of solar radiation that hillslopes receive. Different slope aspects can affect permafrost distribution which can, in turn, cause changes in hillslope hydrological processes (Woo, 1990). For example, north facing slopes underlain by permafrost and capped with an organic soil cover limit percolation to the organic soils and south facing slopes underlain by seasonal frost do not limit percolation. Therefore, runoff generation is often confined to hillslopes underlain with permafrost and capped by organic soils as they limit deep percolation of meltwater (Carey and Woo, 2001). Once the storage capacity of the organic layer is exceeded, lateral runoff 
begins to occur. This is thought to be the primary mode of water delivery from hillslopes to streams, however, preferential pathways such as soil pipes (Carey and Woo, 2000), water tracks (Kane et al., 1989) and mineral earth hummocks (Quinton and Marsh, 1998) are also important components of runoff generation.

Runoff generation processes have previously been studied in Granger Basin (Carey and Woo, 2001; Carey and Quinton, 2004, 2005; McCartney et al., 2006; Quinton et al., 2009) and hydrometric evidence has lead to the development of a hillslope scale conceptual model of runoff generation. The hillslope scale conceptual model developed by Carey and Woo (2001) and Carey and Quinton (2004) to describe how snowmelt is transformed into streamflow in Granger Basin is as follows:

(i) meltwater percolates from the snowpack and infiltrates frozen unsaturated organic soils.

(ii) organic soils thaw and become saturated with snowmelt. Prior to this there is little lateral transfer of water to the stream until the storage capacity of the soils is reached.

(iii) snowmelt runoff is rapidly conveyed to the stream through organic soils and preferential pathways. This runoff is confined to permafrost-underlain slopes, due to their ability to restrict percolation, and to areas directly adjacent to the stream.

(iv) as thaw continues, snowmelt water is able to percolate, interact and mix with the mineral substrate and pre-event waters to contribute to streamflow generation.

Similar conceptual models of snowmelt runoff generation have been proposed by other studies conducted in similar environments (Dingman, 1971; Santeford, 1979; Slaughter and Kane, 1979; McNamara et al., 1997; Quinton and Marsh, 1998). 


\subsubsection{Aufeis and Channel Ice}

Throughout the winter in northern environments active hydrological processes are limited to the freezing of soil moisture in the active layer, the redistribution of snow by wind processes and the formation of aufeis (Hinzman et al., 2005). Aufeis is a German word which is synonymous with the English word icing and the Russian term naled (Carey, 1973). Aufeis has previously been defined as a mass of layered ice that forms due to successive overflow events of groundwater baseflow throughout the winter season (Pollard and Van Everdingen, 1992; Reedyk et al., 1995). Channel ice and aufeis have previously been identified as potential water sources for streamflow (Woo, 1986), although recently their study is relatively rare.

The literature pertaining to aufeis is diverse and includes extensive bibliographies (Chekotillo et al., 1960; Williams, 1965; Carey, 1970, 1973) and reviews (Church, 1974; Grey and MacKay, 1977); yet, in the past, the focus of many investigations has been solely descriptive. Although such studies provide valuable insight into the distribution of aufeis and its effects on infrastructure, they tend not to address the physical processes that relate to the hydrological importance of such icing features (Leffingwell, 1919; Alekeyev et al., 1969; Sloan et al., 1975; Anisimova et al., 1973; Harden et al., 1977; Sokolov, 1978; Slaughter, 1990; Van Everdingen, 1982).

The history of aufeis research dates back more than 150 years. The presence of aufeis has been documented throughout Arctic regions worldwide in a variety of studies such as those undertaken in Mongolia (Froenhlich and Slupik, 1982), Tibet (Zhou et al., 2000), Norway ( $\AA$ kerman, 1982, Liestøl, 1977), Greenland (Yde and Knudsen, 2005), Russia (Wrangle, 1841; Shumskii, 1964; Rudavin and Federov, 1973; Alekseev and Tolstikhin, 1973, 
Nikitina and Tolstikhin, 1973, Tolstikhin and Tolstikhin, 1976; Grigoriev and Sokolov, 1994); Alaska (Kane and Slaughter, 1972; Holmgren et al., 1974; Sloan et al., 1975; Harden et al., 1977; Kane, 1981; Hall, 1980; Slaughter, 1982) and Canada (Williams and Van Everdingen, 1975; Veillette and Thomas, 1979; Van Everdingen and Allen, 1983; Harris et al., 1983; Wankiewicz, 1984; Van Everdingen, 1988; Lauriol et al., 1991; Clark and Lauriol, 1992, 1997; Reedyk et al., 1995; Hu and Pollard, 1997; Pollard, 2005). The largest documented aufeis feature $\left(70-110 \mathrm{~km}^{2}\right)$ is located on the Moma River in Siberia (Tolstikhin and Tolstikhin, 1976).

The role that both aufeis and channel ice play in streamflow generation is poorly understood. They are both important hydrological features of watersheds due to the fact that they are able to store water throughout the winter months and redistribute it to the spring melt period. Channel ice and aufeis are second only to snow cover as the largest temporary surface storage reservoir of fresh water during the winter months in unglaciated basins (Yoshikawa et al., 2007). It is therefore important to quantify and examine the inputs of water from ice melt during the spring melt period in order to accurately quantify the hydrometric and hydrochemical role that this important streamflow source area plays in watersheds affected by their presence.

Despite the fact that aufeis and channel ice have been determined to be important features of Arctic and Subarctic watersheds they continue to be ignored in many catchment water balance and hydrograph separation studies. The result of this is that investigators may overestimate the annual baseflow contribution to streamflow as the chemical signature of aufeis and channel ice is very similar to that of baseflow. For example, Van Everdingen 
(1982) showed that some cold region rivers and streams may store their entire winter baseflow as channel ice and aufeis. If the large amount of resulting melt water is not determined to come from icing features then its chemical and isotopic signature is interpreted as direct groundwater contribution. It is important to consider the influence of these icing features as many studies have demonstrated their potential to augment streamflow (Kane and Slaughter, 1972; Chistotinova and Tolstikhin, 1973; Sokolov, 1978; Van Everdingen, 1987; Lauriol et al., 1991; Reedyk et al., 1995; Clark and Lauriol, 1997).

\subsection{Water Balance}

Water balance studies form the foundation of our understanding of catchment hydrology as they provide the most basic information concerning a region's hydrology (Dingman, 2002). Accurate quantification of precipitation, streamflow, snow cover and evaporation are critical for calculating a catchment water balance. For cold regions, the water balance can be described as:

$$
P+M-Q-E=\Delta S
$$

where $P$ is precipitation, $M$ is snowmelt, $Q$ is discharge, $E$ is evaporation and $\Delta S$ is the change in all forms of storage within the basin (Dingman, 2002). The dimensions of these quantities over time can be in meters cubed $\left(\mathrm{m}^{3}\right)$ or in meters $(\mathrm{m})$ if divided by the drainage area of the basin.

Many baseline water balance studies were conducted in permafrost regions throughout the 1970s (Cogley and McCann, 1975; Holecek and Vosahlo, 1975; Wedel et al., 1977; Newbury et al., 1979; Wright, 1981). Similar studies continued to further our understanding of northern hydrological processes after the 1970 s, including experiments in 
snowmelt, evaporation, soil moisture redistribution and freeze-thaw processes (Price and Dunne, 1976; Addison, 1977; Rouse et al., 1977; Heron and Woo, 1978; Sheppard et al., 1978; Jame and Norum, 1980; Marsh et al., 1981; Ohmura, 1982; Moore, 1983).

A number of relatively recent water balance investigations have been conducted in the Subarctic during the snowmelt period (Kane et al., 1991; Woo and Young, 1997; Carey and Woo, 1998; McCartney et al., 2006) and the following general conclusions have be drawn: (i) snowfall represents the majority of annual precipitation; (ii) snowmelt constitutes most of the annual runoff in nival regimes; (iii) precipitation is a large proportion of runoff; and (iv) basin storage is dynamic because storage within active layers is highly temporally and spatially variable (Woo, 1990). Metcalfe and Buttle (1999) noted that large differences in water balance component fluxes were controlled by variations in snowpack properties, precipitation characteristics, ground thaw depths and storage properties.

Precipitation, snowmelt and discharge can be measured using a variety of well established techniques, however, evaporation is difficult to measure accurately and directly (Kane et al., 1991). There are several approaches, yet one widely applied in permafrost regions that requires less field measurements and instrumentation, is the Priestley and Taylor (1972) equation. A modified Priestley and Taylor approach is presented below:

$$
E=\alpha \frac{\sigma}{\sigma+\lambda} \frac{Q^{*}-Q_{G}}{\rho_{w} L_{v}}
$$

where $E$ is evaporation, $\alpha$ is the Priestley and Taylor parameter that relates actual to potential evaporation, $\sigma$ is the slope of the saturated vapor pressure curve, $\lambda$ is the psychometric constant, $Q^{*}$ is net radiation, $Q_{\mathrm{G}}$ is the ground heat flux, $\rho_{\mathrm{w}}$ is the density of water and $L_{\mathrm{v}}$ is 
the latent heat of vaporization (Woo, 1986; Carey and Woo, 2001). The use of this equation requires knowledge of the Priestly and Taylor parameter $(\alpha)$ for the area (Woo, 1986).

Soils can hold a varying amount of water based on their porosity and bulk density. Soil water content changes throughout the year in Subarctic ecosystems as water infiltrates and percolates into soils and either becomes stored in the catchment or is transferred to the stream as runoff (Dingman, 1971; Santeford, 1979; Slaughter and Kane, 1979; Carey and Woo, 1998; Carey and Quinton, 2004). Soil water content can be measured using a variety of techniques although the change in storage $(\Delta S)$ in the water balance equation is often determined as a residual term which can make true validation of the results very difficult. This also results in all the error associated with the other water balance component calculations accumulating in this term.

An accurate water balance provides a good starting point for the study of catchment hydrology as well as a conceptual framework of the hydrological cycle which can be used to check the validity of other aspects of hydrological investigations. Water balance studies also offer a common platform on which a variety of disciplines and investigations can relate their findings to one another.

\section{$2.4 \quad$ Isotope and Ion Tracers}

The chemical and isotopic properties of water provide a unique opportunity to study the source areas of runoff, flow pathways, residence times, reservoir volumes and hydraulic characteristics of flow systems. Historically, runoff generation research in permafrost regions has been primarily hydrometric (Lewkowicz and Young, 1990; Quinton and Marsh, 1998; Carey and Woo, 2001; Dingman, 2002; Spence and Woo, 2003). Since the 1990s, 
hydrometric studies have been applied in combination with isotopic and hydrochemical measurements in order to elucidate source areas, residence times and runoff pathways (Maule and Stein, 1990; Maloszewki and Zuber, 1992; Bonell, 1993; Buttle, 1994; Brown et al., 1999; Soulsby et al., 2004). This type of approach has proven to be useful due to the fact that: (i) stable isotopes do not participate in chemical reactions thus providing key information concerning original source areas; and (ii) dissolved solutes do participate in chemical reactions thus providing critical information concerning flow pathways (Hooper and Shoemaker, 1986; Maule and Stein, 1990; Rice and Hornburger, 1998; Hoeg et al., 2000; Ladouche et al., 2001).

\subsubsection{Stable Isotopes}

The naturally occurring environmental isotopes that are incorporated into the water molecule, $\mathrm{H}_{2}{ }^{18} \mathrm{O}$ and ${ }^{1} \mathrm{H}^{2} \mathrm{H}^{16} \mathrm{O}$, have been used for over 35 years in the study of streamflow generation in snowmelt dominated catchments (Kendall and McDonnell, 1998). The early works of Dansgaard (1954), Craig (1961) and Friedman et al. (1964) focused mainly on the isotope variations found in natural waters. Craig and Gordon (1965) developed a theory regarding the isotopic fractionation that occurs during evaporation and Dinçer et al. (1970) conducted one of the first peer reviewed tracer studies of snowmelt runoff. Since then, a variety of studies have explored the use of isotopes under a range of varying field conditions (Frtiz and Fontes, 1980; Gat and Gonfiantini, 1981; Gat, 1996; Clark and Fritz, 1997; Kendall and McDonnell, 1998; Gibson and Prowse, 2000). A comprehensive review concerning the application of isotope tracers to hydrological studies was published by Mook (2000). The benefit of the use of isotopes is the fact that they are not subject to chemical 
reactions during contact with mineral matter and only change (i.e. fractionate) during evaporation or condensation.

Isotopic ratios are conventionally expressed as $\delta$ values which represent a deviation in per mil (\%o) from the isotopic composition of a specified standard. The most widely used and accepted standard in hydrological applications is the Vienna standard mean ocean water (V-SMOW). The isotopic composition of this standard approximates the bulk isotopic composition of the global ocean reservoir. The $\delta^{18} \mathrm{O}$ and $\delta^{2} \mathrm{H}$ for this standard are therefore defined as exactly $0 \%$. Equation 2-3 defines the relationship between measured isotope compositions and a standard:

$$
\delta^{18} \mathrm{O} \text { or } \delta^{2} \mathrm{H}=1000 \times\left[\left(\frac{R_{\text {sample }}}{R_{\text {stan dard }}}\right)-1\right]
$$

where $\mathrm{R}$ refers to the ${ }^{2} \mathrm{H} /{ }^{1} \mathrm{H}$ or ${ }^{18} \mathrm{O} /{ }^{16} \mathrm{O}$ ratios in both the sample and the standard. The use of the $\delta$ scale referenced to $\mathrm{V}$-SMOW results in most precipitation and continental waters having negative $\delta$ values, thus indicating a lower heavy isotope content relative to the world's oceans (Gibson et al., 2005).

The ${ }^{18} \mathrm{O}$ and ${ }^{2} \mathrm{H}$ isotopes in precipitation exhibit a strong linear correlation which reflects the mass based partitioning of isotopes in the water cycle. This correlation is illustrated by the global meteoric water line (MWL). The MWL is defined as:

$$
\delta^{2} H=8.13 \delta^{18} O+10.8
$$

This relationship approximates the observed correlation between $\delta^{18} \mathrm{O}$ and $\delta^{2} \mathrm{H}$ in mean annual precipitation values throughout the world (Gibson et al., 2005) and was first observed by Craig (1961) in global freshwaters. In general, water that has undergone evaporation will have a lower slope than the MWL as well as a changed y-intercept (Figure 2.1). This 
distinction is useful in evaluating whether or not water has been subject to isotopic fractionation during evaporation.

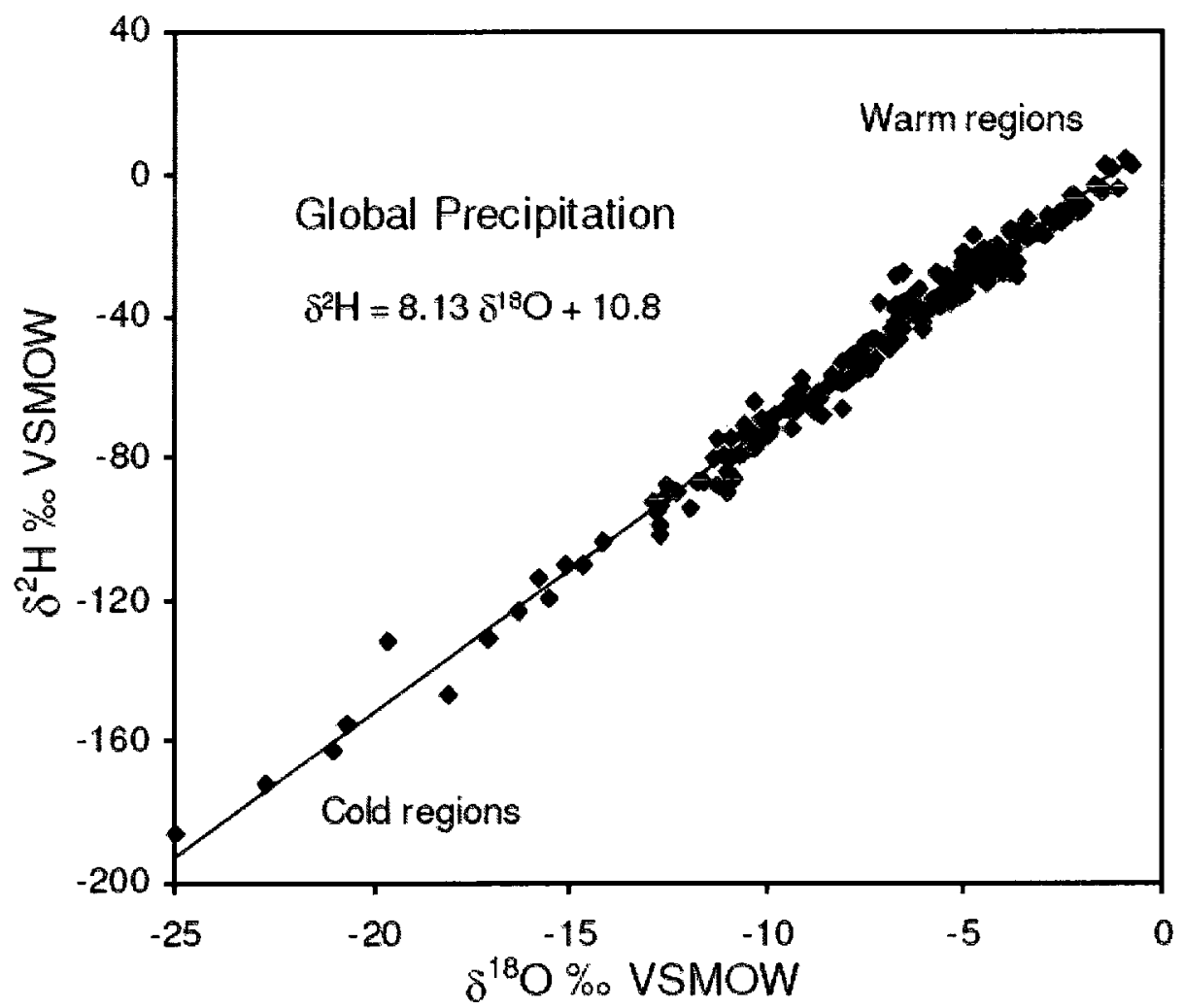

Figure 2.1. The $\delta^{18} \mathrm{O}-\delta^{2} \mathrm{H}$ correlation for global precipitation plotted from data on the International Atomoic Energy Agency GNIP database (Clark, 2008).

The basic reason for fractionation during evaporation and condensation is that the vapor pressure of $\mathrm{H}_{2}{ }^{16} \mathrm{O}$ is slightly higher than that of $\mathrm{H}_{2}{ }^{18} \mathrm{O}$ due to their differences in mass. This difference in vapor pressures results in an enrichment of heavier isotopes in the liquid phase and an enrichment of lighter molecules in the vapor phase in both the condensation and evaporation processes (Obradovic and Sklash, 1986).

Atmospheric moisture arises from a well mixed source, mainly the subtropical ocean surface and this atmospheric moisture progressively looses heavy isotopes during 
precipitation events as it travels towards higher latitudes. The result of this fractionation is lower quantities of heavy isotopes (i.e. more negative $\delta$ values) in high latitude and continental precipitation (Figure 2.2).

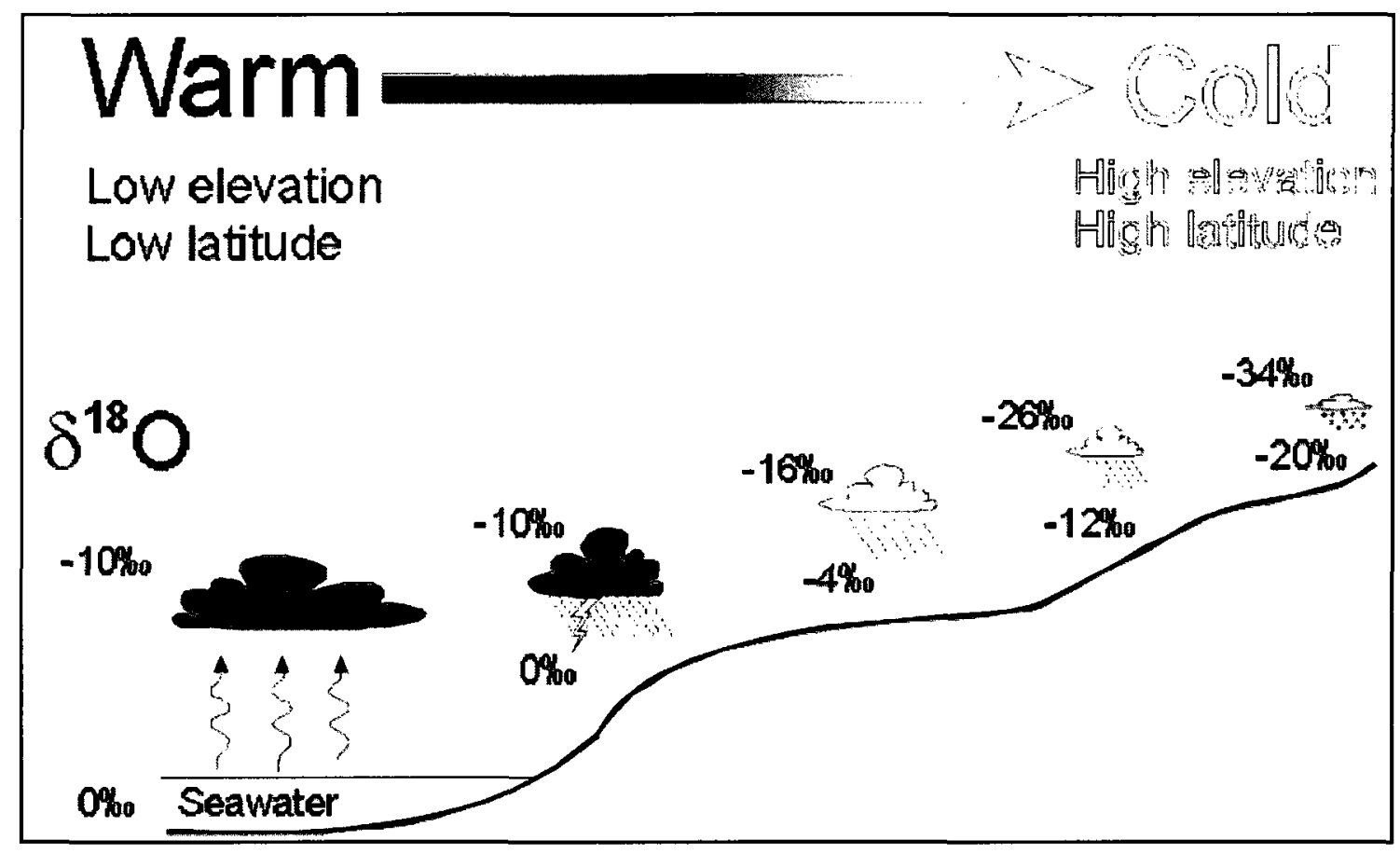

Figure 2.2. Conceptual drawing of the change in ${ }^{18} \mathrm{O}$ content of precipitation according to a Rayleigh distillation (Clark, 2008).

Despite the assumption that isotopes act conservatively (i.e. they do not change during streamflow generation), the determination of snowmelt contributions to streamflow or groundwater is complicated by the process of isotopic fractionation during snow formation, accumulation, ablation and phase changes during melt. In general, winter precipitation in cold regions is strongly depleted and more variable in heavy isotope content relative to summer precipitation (Kendall and McDonnel, 1998). Another observed trend is the fractionation that occurs during snowmelt. Typically, water depleted in heavy isotopes is released at the beginning of the melt period which results in the remaining snow becoming relatively enriched in heavy isotopes. As the melt season proceeds, the isotopic content of 
the meltwater will continue to shift towards more positive $\delta$ values (Rodhe, 1981; Stickler et al., 1981; Cooper et al., 1991; Shanley et al., 1995; Kendall and McDonnel, 1998; Taylor et al., 2001; Feng et al., 2002).

The fractionation of snowmelt is problematic as it becomes difficult to determine an accurate snowmelt isotope signature (Laudon et al., 2002, 2004). In the past, depth integrated snow cores have been used to define the snowmelt isotope signature. However, recent studies have used snow lysimeters to collect meltwater which helps to account for the isotopic variability of meltwater leaving the snowpack (Hooper and Shoemaker, 1986; Stichler et al., 1986; Moore, 1989; Maule and Stein, 1990; Wels et al., 1991; Shanley et al., 2002). Some studies have shown that the isotopic content of meltwater integrated throughout the melt period would be identical to the initial snow isotopic content regardless of fractionation (Kendall and McDonnell, 1998). Others have reported up to $1-4 \%$ enrichment in the $\delta^{18} \mathrm{O}$ of meltwater (Feng et al., 2002; Taylor et al., 2002).

Ice has been shown to melt without any observable isotopic fractionation due to the low diffusion coefficients of isotopically heavy water molecules in solid ice. Despite the fact that much progress has been made, there are still uncertainties related to the mechanism of snowmelt isotope fractionation and how to integrate snowmelt inputs over time. These uncertainties suggest the need to explore the use of alternative tracers, such as major ions, to help validate and interpret the results obtained via isotope tracer studies.

\subsubsection{Major Ions}


Unlike isotopes, hydrochemical tracers change as they interact with organic and inorganic material throughout their passage through the water cycle. It is this characteristic feature that allows hydrochemical tracers to be used to determine the geographic sources and flow pathways of water (Wels et al., 1991; Hinton et al., 1994; Peters et al., 1998). Numerous studies have examined the relationships between the concentration of solutes in stream water and hydrological processes in order to gain insight regarding concentrationdischarge patterns or conceptual mixing models (Johnson et al., 1969; Whitehead et al., 1981; Hooper and Shoemaker, 1986; Hooper et al., 1990; Langmuir, 1997; Kendall and McDonnell, 1998; Hoeg et al., 2000).

The hydrochemistry of natural waters depends on a combination of numerous factors such as geology, climate, ecology and hydrology. Groundwater tends to contain more dissolved solids than surface waters due to longer residence times which results in processes such as adsorption, oxidation, reduction, dissolution and cation exchange. Mineral weathering is the dominant source of solutes in unpolluted catchments (Drever, 2002). Weathering is accelerated by temperature and precipitation thus resulting in temperate and tropical regions demonstrating much higher weathering rates than cold region environments (Woo, 1986). Soil ion exchange is another prominent source of solutes. As the soil solution is altered (due to precipitation, evaporation or plant growth cycles) ions are exchanged between the solid phase and the soil solution.

Runoff sources and flow pathways can be determined using the unique chemical signatures of each of these components. A commonly accepted progression of streamflow generation is: (i) baseflow $\left(C_{G}\right)$; (ii) channel/surface event water $\left(C_{M}\right)$; (iii) soil water $\left(C_{S}\right)$; and 
(iv) baseflow $\left(\mathrm{C}_{\mathrm{G}}\right)$ (Swistock et al., 1989; Fulcar, 1990; Pionke et. al., 1988; DeWalle and Pionke, 1994). The chemistry of these runoff components is often used to determine the progression of streamflow generation by plotting concentration versus discharge.

Concentration-discharge plots depict distinct characteristics regarding component chemistry and the evolution of streamflow generation. Evans and Davies (1998) outline three basic criteria needed to characterize the various types of graphs and hysteresis loops (Figure 2.3).

The first criterion is the rotational pattern (clockwise/anticlockwise). During any event in which three components concentrations are different, a hysteresis loop will be either clockwise or anticlockwise. For a clockwise loop (C1, C2 and C3) the total concentration will be higher on the rising limb than the falling limb. The concentration in soil water $\left(C_{S}\right)$ must therefore exceed the concentration in meltwater $\left(\mathrm{C}_{\mathrm{M}}\right)$. Conversely, an anticlockwise loop (A1, A2 and A3) indicates that the meltwater concentration $\left(C_{M}\right)$ must exceed the soil water concentration $\left(\mathrm{C}_{\mathrm{S}}\right)$.

The second criterion is curvature (convex/concave). This relates to the shape of the entire loop as a whole. A convex loop indicates that on one limb the total concentration must tend towards a value greater that the groundwater concentration $\left(\mathrm{C}_{\mathrm{G}}\right)$ and on the other limb it must have a value less than the groundwater concentration $\left(\mathrm{C}_{\mathrm{G}}\right)$. Therefore, the groundwater concentration must be intermediate relative to the other components. A concave loop implies that the groundwater concentration must have either the highest or lowest component concentration. 
The third criterion is the trend (positive/negative) which should only be considered when the loop is concave in shape. A positive trend indicates that the total concentration is consistently higher during the event than it is at baseflow, and therefore the groundwater concentration $\left(\mathrm{C}_{\mathrm{G}}\right)$ has the lowest concentration of the three components. A negative trend implies the opposite, that the concentration in groundwater $\left(C_{G}\right)$ has the highest concentration.

These three criteria allow the episodic behavior of a given solute to be determined. They can also be used to determine the solute behavior of a two component mixing event such as pre-event and event water. Table 2.1 outlines the diagnostic features used and what they imply and Figure 2.3 depicts the 6 different types of concentration-discharge relationships that can be produced.

Table 2.1. Diagnostic features used by Evans and Davies (1998). Where $C$ is equal to solute concentration and the subscripts $M, G$ and $S$ represent the runoff components of snowmelt water, groundwater and soil water respectively.

\begin{tabular}{|l|l|l|l|l|l|}
\hline Type & $\begin{array}{c}\text { Rotational } \\
\text { Direction }\end{array}$ & Curvature & Trend & $\begin{array}{c}\text { Relative Three } \\
\text { Component } \\
\text { Contribution }\end{array}$ & $\begin{array}{c}\text { Relative Two } \\
\text { Component } \\
\text { Contribution }\end{array}$ \\
\hline $\mathrm{C} 1$ & Clockwise & Convex & N/A & $C_{M}>C_{G}>C_{S}$ & N/A \\
\hline$C 2$ & Clockwise & Concave & Positive & $C_{M}>C_{S}>C_{G}$ & $C_{\text {EVENT }}>C_{\text {PRE-EVENT }}$ \\
\hline$C 3$ & Clockwise & Concave & Negative & $C_{G}>C_{M}>C_{S}$ & $C_{\text {PRE-EVENT }}>C_{E V E N T}$ \\
\hline$A 1$ & Anticlockwise & Convex & N/A & $C_{S}>C_{G}>C_{M}$ & N/A \\
\hline$A 2$ & Anticlockwise & Concave & Positive & $C_{S}>C_{M}>C_{G}$ & $C_{E V E N T}>C_{\text {PRE_EVENT }}$ \\
\hline$A 3$ & Anticlockwise & Concave & Negative & $C_{G}>C_{S}>C_{M}$ & $C_{\text {PREEEVENT }}>C_{\text {EVENT }}$ \\
\hline
\end{tabular}
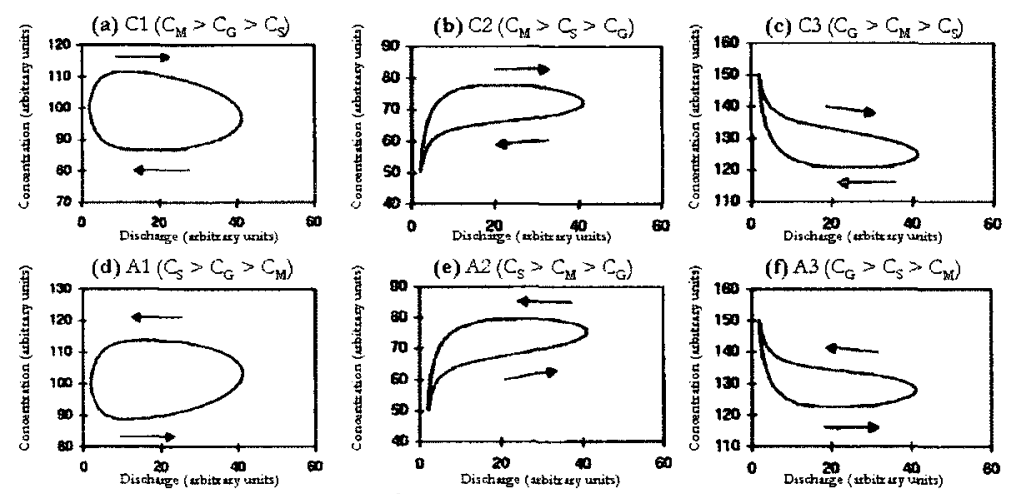

Figure 2.3. Conceptual representation of concentration-discharge plots modified from Evans $\&$ Davies (1998). 
Another useful way to analyze chemical data is to plot concentration versus discharge on log-log axes with a consistent number of log units for both concentration and discharge (Godsey et al., 2009). Concentration-discharge plots are often linear on logarithmic axes, thus indicating that there is a power-law relationship between concentration (C) and discharge $(\mathrm{Q})$ such that $\mathrm{C}=\mathrm{aQ} \mathrm{Q}^{\mathrm{b}}$ (where $\mathrm{a}$ and $\mathrm{b}$ are constants). The exponent of this powerlaw relationship (also the slope of the concentration-discharge relationship on logarithmic axes) can provide useful information regarding the behavior of the solute under examination. A slope of zero indicates that the solute behaves chemostatically (i.e. when the concentration of a solute remains constant as the discharge varies). Conversely, a slope of -1 would indicate that the concentration of the solute varies inversely with discharge (i.e. as discharge increases, solute concentration would decrease). This graphing method can provide insight into the coupling of chemical weathering and hydrological processes in catchments (Godsey et al., 2009).

Aqueous molar ratios of solutes, such as potassium and calcium $(\mathrm{K}: \mathrm{Ca})$, can help to elucidate various water pathways. Large ratios (high potassium:low calcium) denote fast or surface pathways and small ratios (low potassium:high calcium) represent slower subsurface pathways (Elsenbeer et al., 1995). This interpretation is based on the assumption that a vertical zonation of potassium and calcium exists in the from the organic layer to the bedrock in the study area, with decreasing potassium with depth due to uptake and immobilization and increasing calcium with depth due to greater weathering. Elsenbeer $e t$ al. (1995) used this technique to determine relative contributions of groundwater and soil water to streamflow. 
The combined use of hydrometric, isotopic and hydrochemical data can lead to the development of more refined conceptual models of runoff generation. Isotope and ion tracers should be used in combination with hydrograph separation and end-member mixing analyses techniques in order to elucidate the volumetric and chemical contribution of various runoff components to streamflow.

\subsection{Hydrograph Separation}

An important and ubiquitous method that is used in streamflow generation investigations is to conceptually label the water that exists in a catchment prior to a runoff event as "pre-event water" (or old water) and water added to a catchment during an event as “event water" (or new water) (Sklash and Farvolden, 1979). Pre-event water is defined as groundwater, vadose water and surface storage water. Event water is defined as rain or snowmelt water. This terminology will be used herein although other studies often employ the old and new water terminology interchangeably.

Chemical and isotope hydrograph separations use hydrometric and hydrochemical data to distinguish the various components that combine to generate streamflow. A critical review of hydrograph separation is provided by Buttle (1994). This review describes how the use of naturally occurring environmental isotopes can enable the separation of streamflow into pre-event and event water components.

Dinçer et al. (1970) pioneered the use of isotopes in hydrograph separations and since then the hydrological community has used hydrograph separations extensively to track runoff generation components throughout the world (Hooper and Shoemaker, 1986; Buttle 
and Sami, 1990; Wels et al., 1991; Rodhe, 1998) and to separate streamflow components into pre-event and event water (Sklash and Farvolden, 1979; Bottomley et al., 1986; Bishop et al., 1990; Maule and Stein, 1990; Gibson et al., 1993; Kendall et al., 1995; Reedyk et al., 1995; Rodhe, 1998; Laudon et al., 2002; Carey and Quinton, 2004; Laudon et al., 2004).

In the past, graphical separations of the discharge hydrograph were conducted via extrapolation of the groundwater recession curve beneath the flood peak. This technique attributed the majority of the hydrograph peak as being derived from overland runoff of event water (Barnes, 1940; Linsley and Franzini, 1964; Pinder and Jones, 1969; Hooper and Shoemaker, 1986). This technique is still used although the use of tracer based hydrograph separations is now a widely accepted method used to determine the contributions of preevent and event water. The majority of studies, despite varying hydrological and geological settings, have shown that pre-event water supplies at least half of the streamflow at peak discharge. Table 2.2 provides a list of hydrograph separations, their location, basin area, tracer used and the percent of pre-event water to streamflow during either a storm event or snowmelt event. In the majority of the studies summarized in Table 2.2 the pre-event water contribution is greater than fifty percent of total streamflow and is often greater than sixty or seventy percent. This is especially true for the studies that conducted hydrograph separations during the snowmelt period (highlighted in Table 2.2).

Hydrograph separations use mass balance equations that describe the contributions of a variety of water sources to streamflow using the flux of conservative tracers within a catchment. If streamflow is determined to come from two components, each of which has a 
Table 2.2. Summary of the findings of a number of studies using tracers to separate streamflow into pre-event and event water.

\begin{tabular}{|c|c|c|c|c|c|}
\hline Reference & Location & $\begin{array}{c}\text { Basin Area } \\
\left(\mathrm{km}^{2}\right)\end{array}$ & Tracer & Event & $\begin{array}{c}\text { Pre-Event Water } \\
\text { Contribution } \\
(\%)\end{array}$ \\
\hline \multirow{3}{*}{ Crouzet et al. (1970) } & \multirow{3}{*}{ France } & 570 & ${ }^{3} \mathrm{H}$ & \multirow{3}{*}{ Storm } & 97 \\
\hline & & 1500 & ${ }^{3} \mathrm{H}$ & & 99 \\
\hline & & 9100 & ${ }^{3} \mathrm{H}$ & & 46 \\
\hline Dinçer et al. $(1970)$ & Czechoslovakia & 2.7 & ${ }^{18} \mathrm{O},{ }^{3} \mathrm{H}$ & Melt & 60 \\
\hline Mook et al. (1974) & Netherlands & 6.5 & ${ }^{18} \mathrm{O}$ & Storm & 70 \\
\hline Martinec (1974) & Switzerland & 43.3 & ${ }^{3} \mathrm{H}$ & Melt & 65 \\
\hline \multirow{3}{*}{ Fritz et al. (1976) } & \multirow{3}{*}{ Canada } & 18 & \multirow{3}{*}{${ }^{18} \mathrm{O}$} & \multirow{3}{*}{ Storm } & 45 \\
\hline & & 22 & & & 60 \\
\hline & & 135 & & & 50 \\
\hline \multirow{7}{*}{ Sklash et al. (1976) } & \multirow{7}{*}{ Canada } & 700 & \multirow{7}{*}{${ }^{18} \mathrm{O}$} & \multirow{7}{*}{ Storm } & 70 \\
\hline & & 400 & & & 71 \\
\hline & & 100 & & & 55 \\
\hline & & 350 & & & 69 \\
\hline & & 170 & & & 52 \\
\hline & & 108 & & & 70 \\
\hline & & 73 & & & 75 \\
\hline Herrmann et al. (1978) & Germany & 18.7 & ${ }^{2} \mathrm{H}$ & Melt & $70-80$ \\
\hline \multirow{3}{*}{ Sklash \& Farvolden (1979) } & \multirow{3}{*}{ Canada } & 1.2 & \multirow{3}{*}{${ }^{18} \mathrm{O}$} & \multirow{3}{*}{ Storm } & 75 \\
\hline & & 3.9 & & & 80 \\
\hline & & 1 & & & 80 \\
\hline \multirow{2}{*}{ Rodhe (1981) } & \multirow{2}{*}{ Sweden } & 6.6 & \multirow{2}{*}{${ }^{18} \mathrm{O}$} & & 90 \\
\hline & & 4 & & Melt & 70 \\
\hline Merot et al. (1981) & France & 0.1 & ${ }^{18} \mathrm{O}$ & Storm & 88 \\
\hline & & 1.2 & & & 90 \\
\hline Bottomley et al. (1984) & Canada & 1.8 & ${ }^{18} \mathrm{O}$ & Melt & 80 \\
\hline & & 10.5 & & & 40 \\
\hline Christophersen et al. (1984) & Norway & 0.4 & ${ }^{18} \mathrm{O}$ & Melt & $60-90$ \\
\hline Obradovic \& Sklash (1986) & Canada & 60 & $\begin{array}{l}{ }^{18} \mathrm{O} \\
\text { chemical }\end{array}$ & Melt & 60 \\
\hline & & 0.4 & & & 80 \\
\hline Sklash et al. (1980) & New Zealand & 0.2 & ${ }^{2} \mathrm{H}$ & Storm & 82 \\
\hline Bottomley et al. (1986) & Canada & 10.5 & ${ }^{18} \mathrm{O}$ & Melt & $50-60$ \\
\hline Hooper \& Shoemaker (1986) & USA & 0.4 & $\begin{array}{l}{ }^{2} \mathrm{H}, \\
\text { chemical }\end{array}$ & Melt & 75 \\
\hline Pearce et al. (1986) & Nevv Zealand & 0.4 & ${ }^{18} \mathrm{O}$ & Storm & 97 \\
\hline Lawrence (1987) & USA & 13 sites & ${ }^{2} \mathrm{H}$ & Melt & 75 \\
\hline & & 0.2 & & & 87 \\
\hline & Sweden & 0.5 & 180 & Melt & $85-99$ \\
\hline Rodhe (198/b) & Sweden & 4 & 100 & Melt & $68-86$ \\
\hline & & 6.6 & & & $75-95$ \\
\hline Herrmann et al. (1987) & Germany & 0.8 & ${ }^{18} \mathrm{O}$ & Storm & 84 \\
\hline Turner et al. (1987) & Australia & 0.8 & ${ }^{2} \mathrm{H},{ }^{18} \mathrm{O}$ & Storm & $69-95$ \\
\hline Ingraham \& Taylor (1989) & USA & 1600 & ${ }^{2} \mathrm{H},{ }^{18} \mathrm{O}$ & Melt & 50 \\
\hline Bonell et al. $(1990)$ & New Zealand & 2.2 & ${ }^{2} \mathrm{H}$ & Storm & 59 \\
\hline Nolan \& Hill (1990) & USA & 10.6 & ${ }^{2} \mathrm{H}$ & Storm & 57 \\
\hline McDonnell et al. (1990) & New Zealand & 3.1 & ${ }^{2} \mathrm{H}$ & Storm & $21-33$ \\
\hline Wels et al. (1990) & Canada & 2 & ${ }^{2} \mathrm{H}, \mathrm{pH}$ & Melt & $49-60$ \\
\hline Cooper et al. (1991) & USA & 2.2 & ${ }^{18} \mathrm{O}$ & Melt & 14 \\
\hline Ogunkoya \& Jenkins (1991) & United Kingdom & 10 & ${ }^{2} \mathrm{H}$ & Storm & $54-90$ \\
\hline McDonnell et al. (1991) & New Zealand & 0.4 & ${ }^{2} \mathrm{H}$ & Storm & $92-100$ \\
\hline Waddington et al. (1993) & Canada & 1.6 & ${ }^{18} \mathrm{O}$ & Storm & $87-93$ \\
\hline Buttle et al. (1995) & Canada & 1.1 & ${ }^{18} \mathrm{O}$ & Melt & $42-52$ \\
\hline Lepisto (1995) & Finland & 1.7 & 180 & Melt & $37-47$ \\
\hline McNamara et al. (1997) & USA & 145 & ${ }^{18} \mathrm{O}$ & Melt & 7 \\
\hline Gibson et al. (2000) & Canada & 0.3 & $\begin{array}{l}{ }^{2} \mathrm{H}, \\
\text { chemical }\end{array}$ & Storm & 85 \\
\hline Hoeg et al. (2000) & Germany & 18.4 & ${ }^{18} \mathrm{O}$ & Storm & 82 \\
\hline Laudon et al. (2002) & Sweden & 0.1 & ${ }^{18} \mathrm{O}$ & Melt & 58 \\
\hline Liu et al. (2004) & USA & 2.3 & ${ }^{18} \mathrm{O}$ & Melt & 53 \\
\hline
\end{tabular}


constant known distinct chemical or isotopic concentration, then the following mass balance equations can be applied (Sklash and Farvolden, 1979):

$$
\begin{aligned}
& \mathrm{Q}_{\mathrm{T}}(t)=Q_{1}(t)+Q_{2}(t) \\
& C_{T}(t) \times Q_{T}(t)=\left(C_{1}(t) \times Q_{1}(t)\right)+\left(C_{2}(t) \times Q_{2}(t)\right)
\end{aligned}
$$

where $C$ is equal to a concentration of a known tracer, $Q$ represents discharge values, $(t)$ is time and the subscripts $\mathrm{T}, 1$, and 2 denote the total streamflow value, the first component of streamflow and the second component of streamflow, respectively. If the total discharge rate, $Q_{T}$, and its concentration, $C_{T}$, are measured then equations (2-5) and (2-6) can be combined in order to calculate the discharge contributed by each component:

$$
\begin{aligned}
& Q_{2}(t)=\left(\frac{\left(C_{T}(t)-C_{1}(t)\right)}{\left(C_{2}(t)-C_{1}(t)\right)}\right) \times Q_{T}(t) \\
& Q_{1}(t)=Q_{T}(t)-Q_{2}(t)
\end{aligned}
$$

These equations have been applied using various chemical and isotopic tracers, however, there are four assumptions outlined by Sklash and Farvolden (1979) that must first be satisfied:

(i) The tracer content of the event component must be significantly different from that of the pre-event component.

(ii) The event component must maintain a constant tracer content.

(iii) The groundwater and vadose water tracer signatures must be equivalent or the vadose water contributions to runoff are negligible.

(iv) Surface storage must contribute minimally to the runoff event.

Failure to meet all of the requirements of the above mentioned assumptions is one of the main drawbacks of hydrograph separations. Rodhe (1987a), Sklash (1990), and Buttle (1994) discuss these assumptions and the implications that they pose for the validity of hydrograph separations. These reviews discovered that the assumptions are often not satisfied, although 
violation of the assumptions does not necessarily compromise the fundamental finding that pre-event water constitutes a large component of storm and snowmelt generated streamflow. Nonetheless, the more closely the assumptions are satisfied the more precise the hydrograph separation will be.

Another issue that is related to hydrograph separations is the double paradox presented by Kirchner (2003). Paradox 1 is the rapid mobilization of pre-event water which states that streamflow responds promptly to event inputs yet fluctuations in tracers often indicate that streamwater is composed primarily of pre-event water. The question that Kirchner (2003) poses is "how do these catchments store water for weeks or months, but then release it in minutes or hours in response to event inputs? Paradox 2 is the variable chemistry of old water which states that concentrations of reactive chemical tracers are often highly sensitive to discharge. The question that Kirchner (2003) then poses is "how do catchments store pre-event water for long periods, but then release it rapidly during an event, and vary its chemistry according to the flow regime?"

This double paradox is one that continues to puzzle hydrologists today. In permafrost-underlain catchments pre-event water has been shown to contribute at least 50 $\%$ of streamflow during the snowmelt period (Obradovic and Sklash, 1986) although in other similar catchments this has not been the case (McNamara et al., 1997). The large apparent contribution of pre-event water to streamflow is hard to explain as hydrometric and tracer based studies suggest that near-surface pathways are important runoff generating areas and only limited quantities of pre-event water is available for runoff generation (Carey et al., 2009). The combined use of a variety of tracer based techniques may help to reveal the 
answers to these often asked questions. In order to fully understand the various hydrological processes that occur in northern environments we must continue to critically examine the use of conservative tracers and hydrograph separation techniques.

The advantage that hydrograph separations and end-member mixing analyses offer is the approximate quantification of the proportions of event and pre-event water contributions to streamflow. The temporal and spatial variability of tracers makes accurate hydrograph separations difficult therefore it is extremely important to develop comprehensive sampling schemes in order to accurately quantify the variability of tracer values over time and space. Kendall and McDonnell (1998) advise that the most important and general recommendation that can be made regarding hydrograph separation studies is to respect the limitations and assumptions of the approach.

\subsection{End-Member Mixing Analysis}

Historically, hydrologists relied heavily on the use of simple graphical hydrograph separation techniques to determine the relative contributions of event and pre-event water to streamflow. More recently, hydrograph separations have been used to determine the contributions of event and pre-event water yet the correct runoff generation mechanisms often remain undetermined. Rather than dividing streamflow components into event and pre-event water, as is done in hydrograph separations, end-member mixing analysis (EMMA) describes streamwater as a mixture of defined end-members such as groundwater, snow meltwater and soil water (Hooper, 2003). These end-members form the chemical boundaries within which streamwater observations are found. 
There are several conditions and assumptions that must be addressed before an

EMMA can be conducted. These criteria are outlined below:

i) End-member chemistry and streamwater chemistry are linked by the assumption that they mix together.

ii) Solutes are assumed to be conservative. That is, they do not participate in chemical reactions.

iii) End-member compositions and tracers are considered invariant in time and space.

iv) There must be differences in the concentration of end-members.

v) No charge balance constraint is imposed.

vi) The chemistry of the mixing zones is ignored. If these areas do control some form of the chemistry then EMMA is conceptually wrong.

vii) So long as end-member water is well distributed and spatial variability is small relative to streamwater, then EMMA remains conceptually correct.

viii) End-members must exhibit concentrations bounding that of the observed stream chemistry.

ix) One must screen the independently sampled geochemical signatures of end-members by projecting them into the mixing space of the catchment and evaluating the difference between observed values and their orthogonal projections.

These assumptions and conditions allow for a number of simple mathematical and multivariate statistical methods to be applied to the data (Hooper, 1990). A conceptual drawing of end-member mixing can be seen in Figure 2.4.

Initially, streamwater samples must be analyzed for major solutes and isotopes that may be appropriate for EMMA. End-member mixing diagrams are used to determine which end-members encompass the streamwater concentrations. Mixing diagrams are $\mathrm{x}-\mathrm{y}$ plots of all the potential combinations of paired tracers of both end-members and streamwater values (Christophersen et al., 1990). 


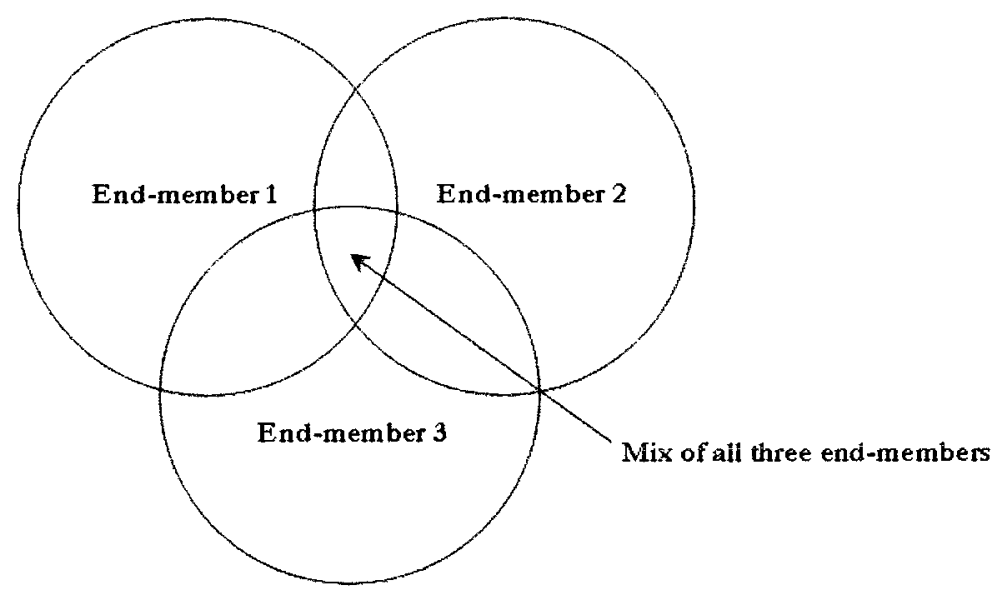

Figure 2.4. Conceptual drawing of end-member mixing.

Figure 2.5 provides an example of an end-member mixing diagram. If the observed streamwater values all fall within the boundaries formed by the end-members then it can be said that the end-members account for the majority of the water contributing to streamflow. Another way of describing this relationship is that the streamwater points that fall within the boundaries of the end-members can be described as the precise mixture of those endmembers for the two tracers plotted on that particular mixing diagram.

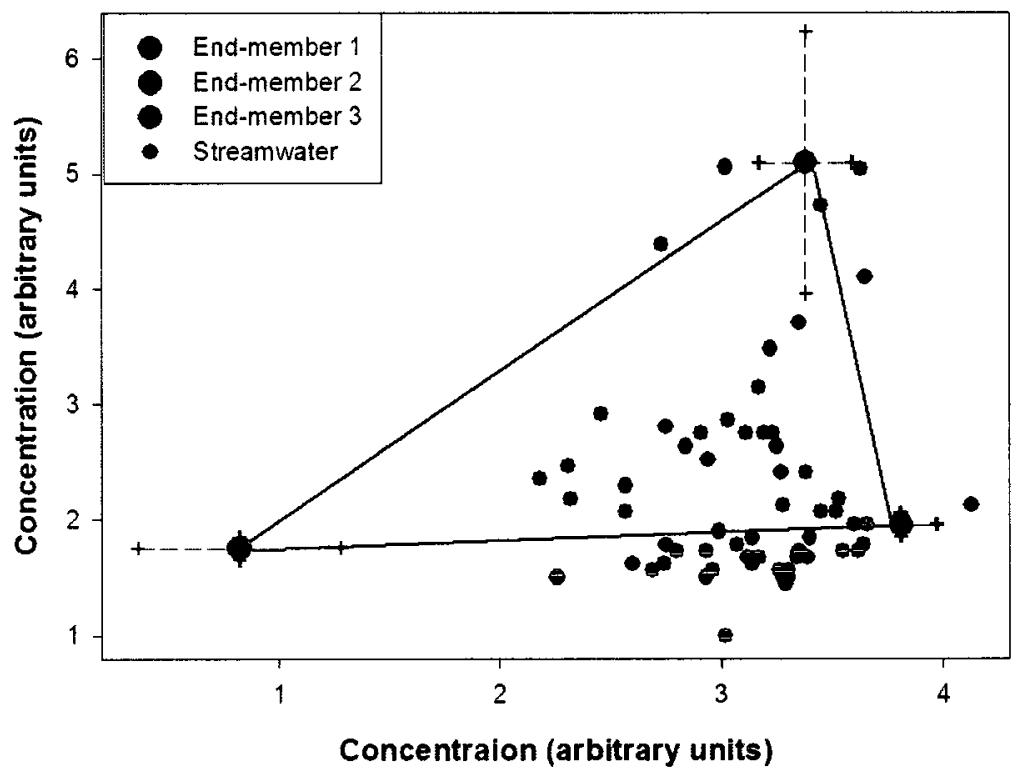

Figure 2.5. Example of an end-member mixing diagram. 
It is important to consider the values that lie outside the "boundary" as they may indicate the need for end-members to be altered in order to contain more of the observed streamwater points. In some cases, mixing diagram anomalies and large outliers may indicate a missing end-member or an extreme event (Hooper et al., 1990; Uhlenbrook and Hoeg, 2003; Liu et al., 2004). If there are no end-members that can account for the streamwater observations then an important component of the watershed may have been overlooked and should be sampled. Ideally, the mixing diagrams should provide the details needed for the development of predictive models that are testable and reliable. These diagrams can be generated with little effort and provide, at the very least, the information needed for improved sampling and experiments (Hooper et al., 1990; Kendall and McDonnell, 1998).

Burns et al. (2001) discussed that improvements in the ability of EMMA to describe runoff generation processes depended upon better spatial and temporal characterization of the source waters that contribute to event runoff. James and Roulet (2006) were interested in using EMMA to determine: i) the dimensionality (number of end-members); ii) what solutes can be assumed to be conservative across scale; and iii) the hydrological interpretation of contributing geographical source waters across scale.

EMMA provides a key tool in the development of hydrochemical models. It is imperative to identify and acknowledge the limitations involved with this method, yet it is also important to acknowledge its success in identifying and describing streamwater mixing processes. Progress continues to be made in the field of modeling and EMMA remains an important component of the past and future of hydrochemical models. 


\section{FIELD AND LABORATORY METHODS}

This study was conducted within Granger Basin $\left(7.6 \mathrm{~km}^{2}\right)$, a small headwater catchment located within the larger Wolf Creek Research Basin $\left(195 \mathrm{~km}^{2}\right)$. The Wolf Creek Research Basin was initiated in 1992 in order to provide a well instrumented location for applied hydrological research in the Yukon Subarctic region. A series of three nested hydrometric stations were established in 1993 and 1994. The stations have been operating continuously since that time, one of which is located at the outlet of Granger Basin. The main objectives of the Wolf Creek Research Basin are to develop an integrated research and monitoring site which enhances and expands upon existing activities that take place in the area. Detailed information regarding the Wolf Creek Research Basin can be found in Pomeroy and Granger (1999).

Snowmelt, ice melt, streamflow and stream hydrochemistry were monitored within Granger Basin from 19 April to 8 July, 2008. The following chapter will describe the climate, geology, ecology and hydrology of the study area. Field and laboratory methods will also be discussed.

\subsection{Site Description}

The Wolf Creek Research Basin is located 15 kilometers south of Whitehorse, Yukon Territory (Figure 3.1). The basin occupies an area of $195 \mathrm{~km}^{2}$ with elevations ranging from $800-2250 \mathrm{~m}$ and a mean elevation of $1325 \mathrm{~m}$. This research was conducted within Granger Basin $\left(60^{\circ} 32^{\prime} \mathrm{N}, 135^{\circ} 18^{\prime} \mathrm{W}\right)$, a small headwater catchment located within the central east region of the Wolf Creek Research Basin. Granger Basin drains an area of $7.6 \mathrm{~km}^{2}$ and ranges in elevation from 1310-2250 $\mathrm{m}$ (Figure 3.2). 


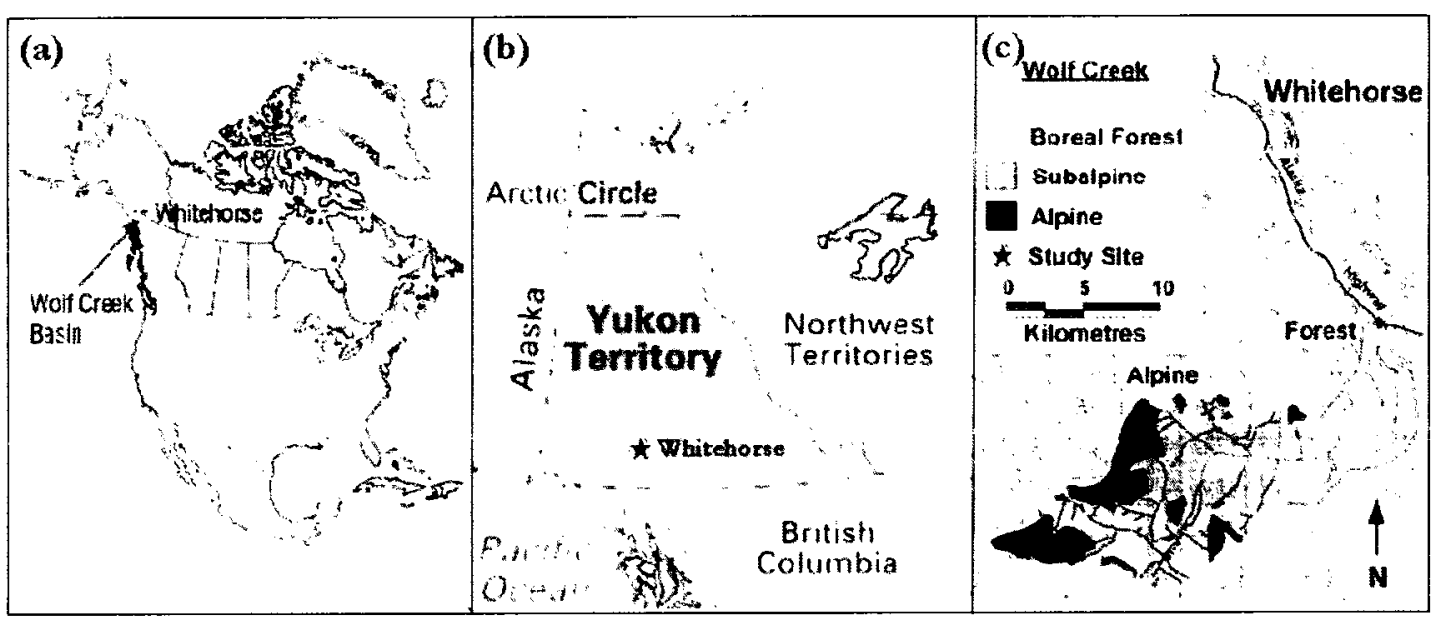

Figure 3.1. Study area map indicating (a) Whitehorse within North America, (b) Whitehorse within the Yukon and (c) the Wolf Creek Research Basin relative to Whitehorse. Modified from Pomeroy and Granger (1999).

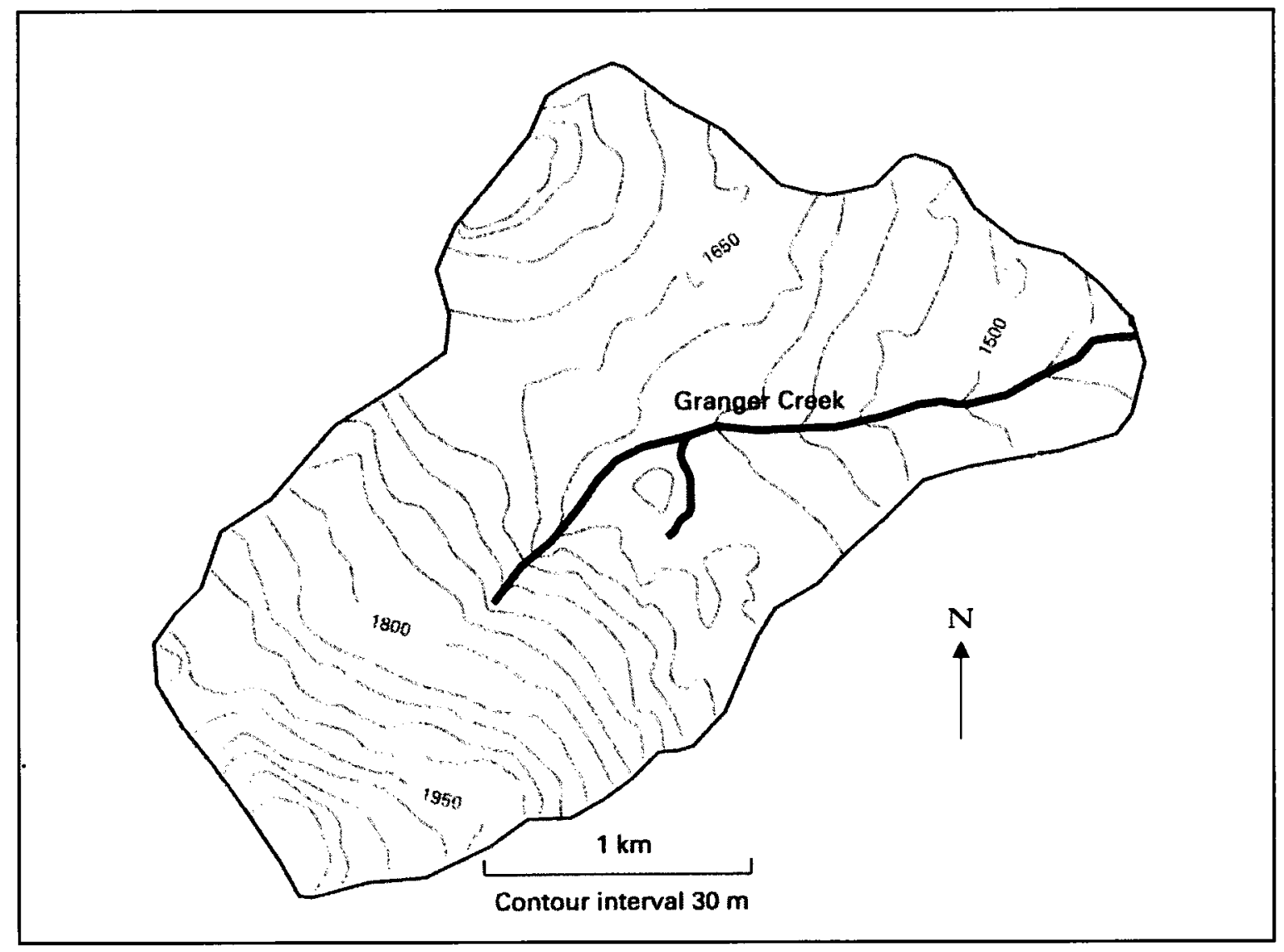

Figure 3.2. Map of Granger Basin. 


\subsubsection{Climate}

The study area has a continental subarctic climate characterized by low precipitation, low relative humidity and a relatively large temperature range. Mean annual precipitation is $300 \mathrm{~mm}$ to $400 \mathrm{~mm}$ and approximately $40 \%$ of the annual precipitation falls as snow. The mean annual temperature is approximately $-3^{\circ} \mathrm{C}$. Summer mean temperatures range from $+5^{\circ} \mathrm{C}$ to $+15^{\circ} \mathrm{C}$ and winter mean temperatures range from $-10^{\circ} \mathrm{C}$ to $-20^{\circ} \mathrm{C}$. Summer and winter extreme temperatures of $+25^{\circ} \mathrm{C}$ and $-40^{\circ} \mathrm{C}$, respectively, have often been recorded (Pomeroy and Granger, 1998).

\subsubsection{Geology}

The geology of the basin is predominantly sedimentary and consists mainly of limestone, siltstone, sandstone and conglomerate. Some volcanic material is also present and is comprised of andesite, basalt and some intrusions of granite. Glacial till overlies most of the basin at depths ranging from centimeters to several meters. Bedrock outcrops are present at higher elevations and the valley bottoms are heavily scoured. A detailed geological description of the study area can be found in Mougeot and Smith (1994).

The basin is located within the sporadic discontinuous permafrost zone (Heginbottom et. al., 1995). Figure 3.3 depicts the various permafrost zones found in Yukon Territory and the relative location of the Wolf Creek Research Basin. A study by Lewkowicz and Ednie (2004) determined that approximately $70-80 \%$ of Granger Basin is underlain by permafrost. The majority of the permafrost found in Granger Basin has been shown to occur under north-facing slopes and at high elevations, whereas south-facing slopes and lower elevation areas tend to be underlain by seasonal frost (Carey and Quinton, 2004). 


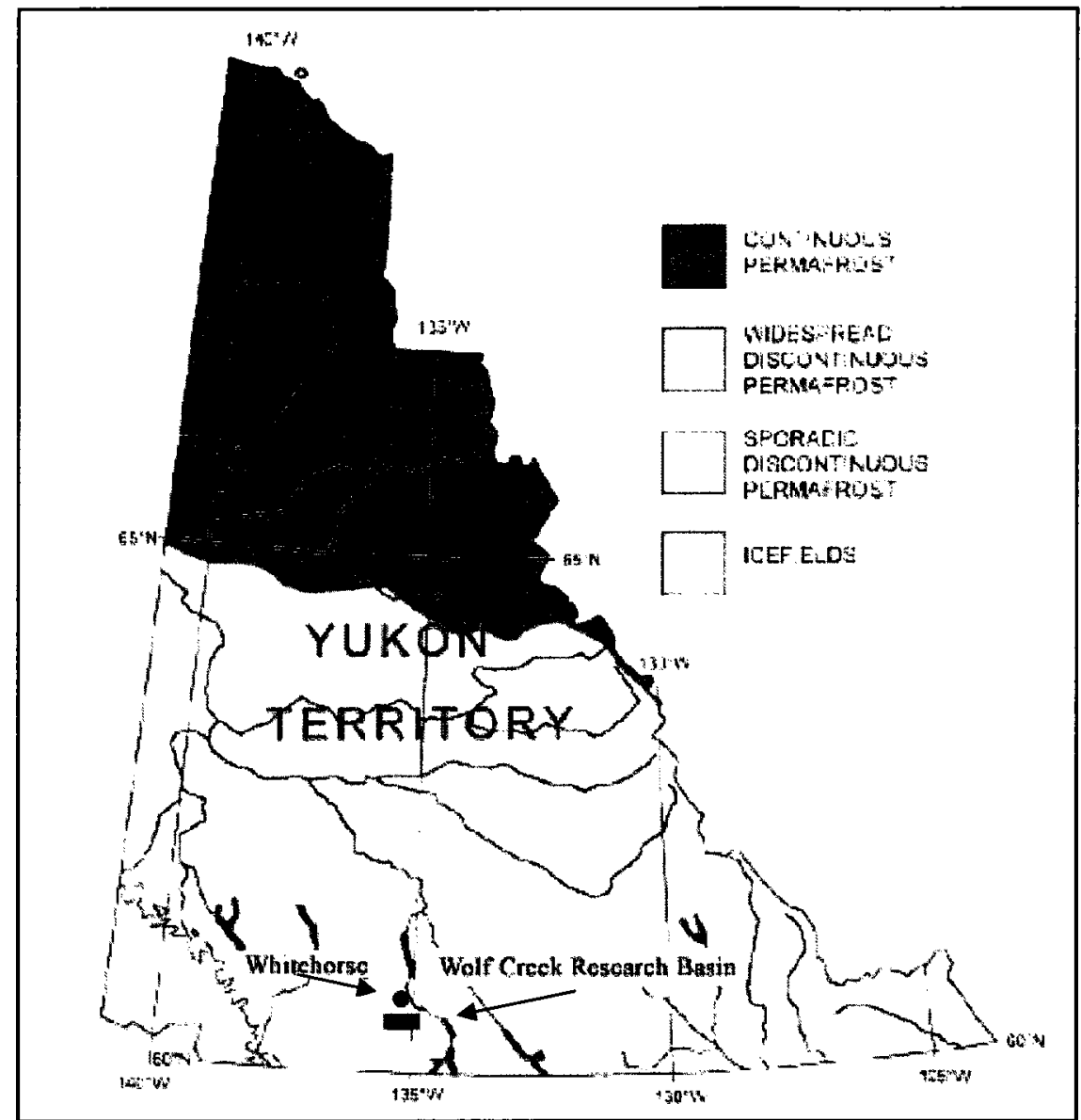

Figure 3.3. Permafrost zones in Yukon Territory and relative location of the Wolf Creek Research Basin (Lewkowicz and Ednie, 2004).

\subsubsection{Ecology}

The Wolf Creek Research Basin is located within the Boreal Cordillera Ecozone and overlaps the Southern Yukon Lakes Ecoregion and the Yukon-Stikine Highlands Ecoregion (Environment Canada, 1995) (Figure 3.4). The basin is comprised of three main ecosystems: 1) boreal forest; 2) subalpine taiga; and 3) alpine tundra. The proportions are 22 percent, 58 percent and 20 percent, respectively. The tree line is located at approximately $1300 \mathrm{~m}$. (Francis, 1997). The ecozone that Granger Basin occupies is the subalpine taiga ecozone which consists of non-vascular plants, such as mosses and lichens, and numerous varieties of low-lying grasses, herbs and shrubs such as dwarf birch and willow. The soils 
found within riparian zones and permafrost areas are capped with an organic layer which can reach depths of up to 40 centimeters. This layer consists of peat, lichen, moss, sedge and grass (Carey and Quinton, 2004).

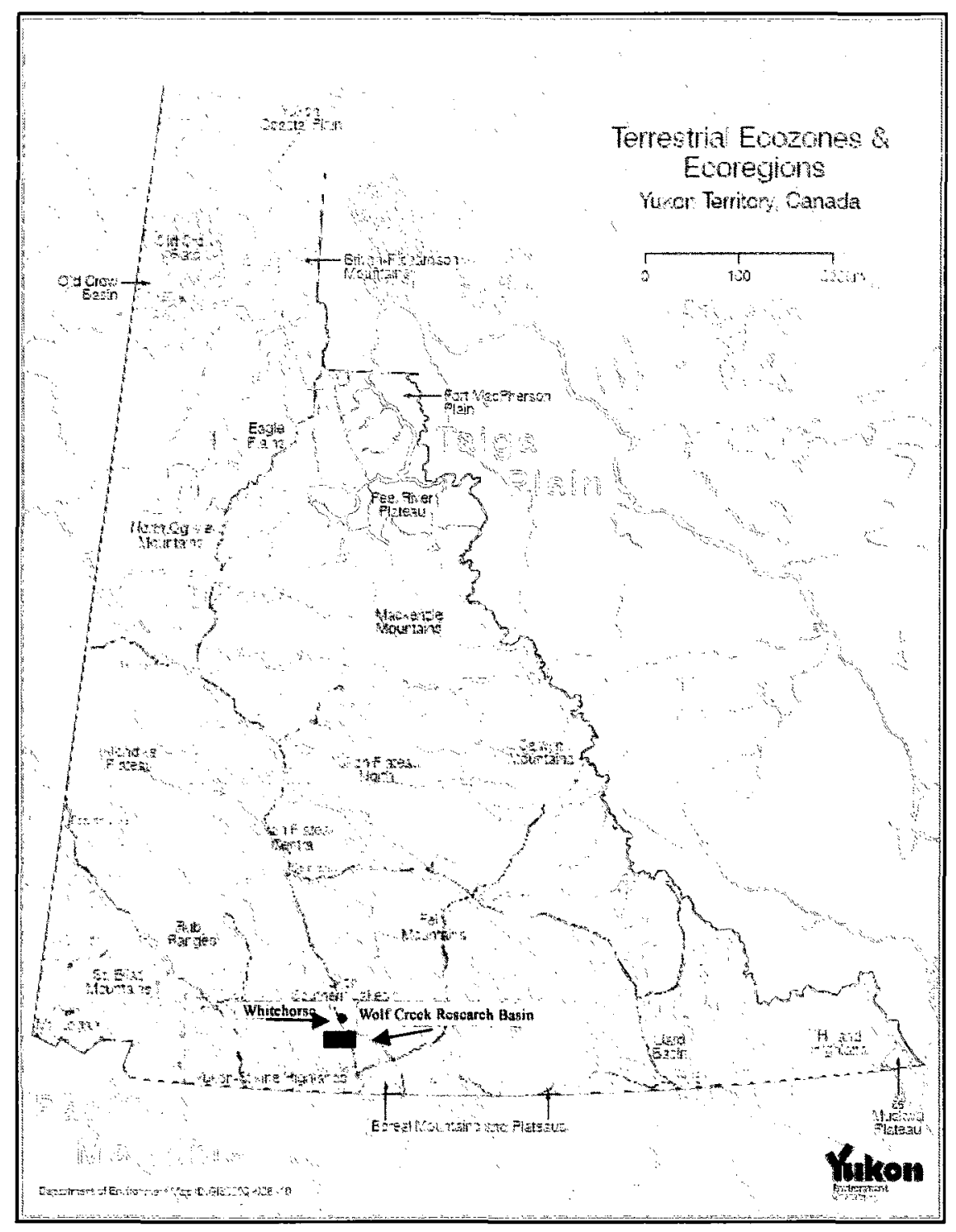

Figure 3.4. Yukon terrestrial ecozones and ecoregions with study area indicated in black.

\subsubsection{Hydrology}

The streamflow observed within Granger Basin is characteristic of a mountainous subarctic nival regime. Stream discharge reaches its peak (approximately $1-2 \mathrm{~m}^{3} \mathrm{~s}^{-1}$ ) in late 
May or early June and low flows (approximately $0.1 \mathrm{~m}^{3} \mathrm{~s}^{-1}$ ) tend to occur in March (Janowicz, 1991). Significant groundwater recharge exists within the basin which results in relatively high winter baseflows. Secondary peaks in the hydrograph are often observed in the summer months due to intense rainstorm events. Extremely cold winters and other favorable conditions have been known to produce aufeis formations within the basin. Small ephemeral channels and water tracks are widespread throughout the basin during the spring melt period, although they tend to dry up in the summer months (McCartney et al., 2006).

\subsection{Field Methods}

The study period began on 19 April and ended on 8 July, 2008. The various methods used to measure stream discharge, meteorological parameters, water quality parameters, water chemistry, snow depth, snow density, ice depth, ice chemistry and the method used to capture time lapse photography images are outlined below. Figure 3.5 depicts the location of: snow transects, discharge monitoring sites, water sampling sites, meteorological towers, aufeis and ice core locations and the location of the tripod for the time lapse photography.

\subsubsection{Discharge monitoring}

A permanent discharge monitoring site exists at the outlet of Granger Basin. This site consists of a stilling well with a float connected to an electronic data logger which logs water depth every 15 minutes. This hydrometric station is one of three nested stations within the Wolf Creek Research Basin and it is monitored and maintained by the Yukon Territorial Government. A stable stage-discharge relationship has existed at the site since 1998. 


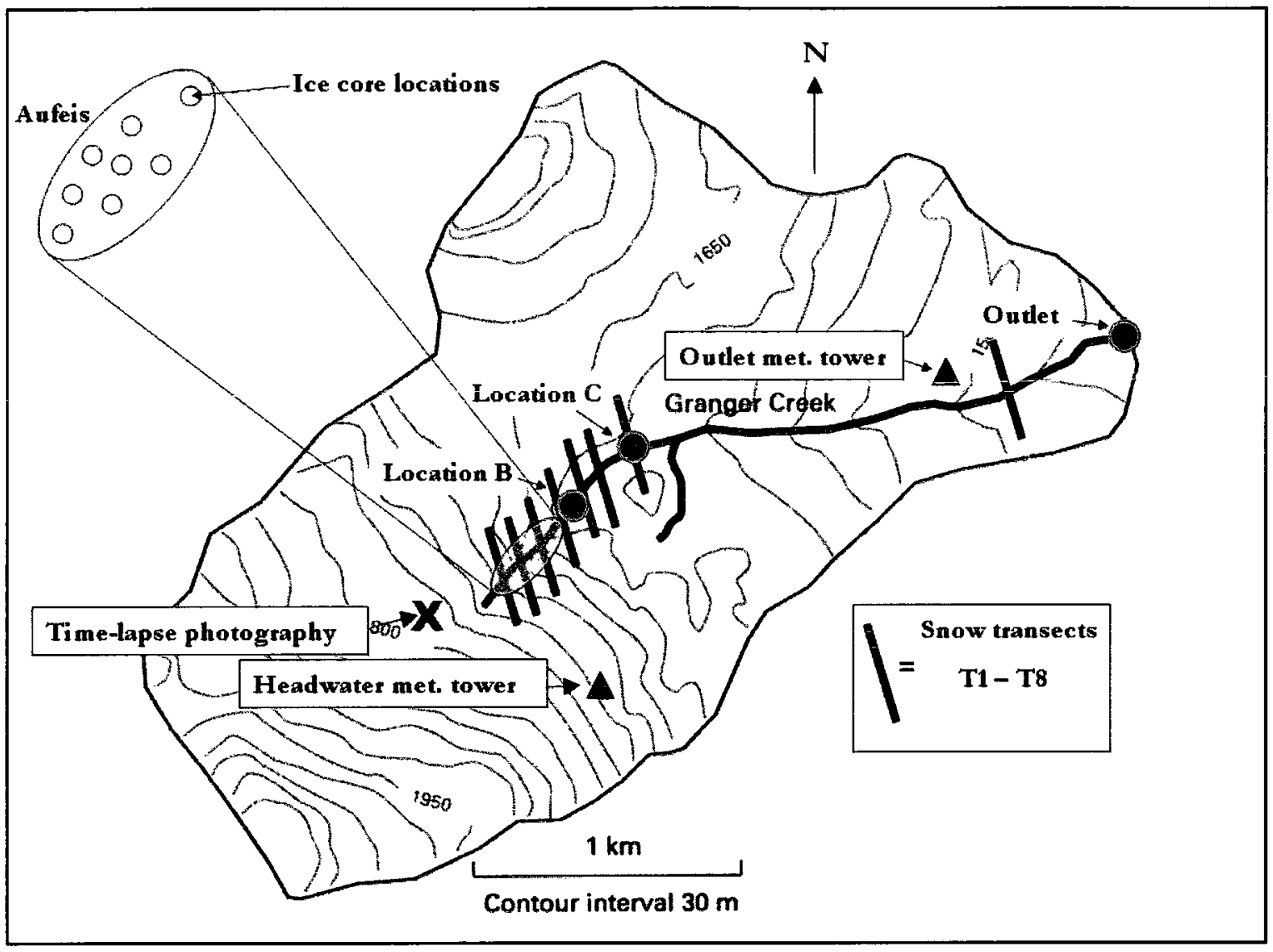

Figure 3.5. Study area map indicating snow transects, water sampling sites, discharge monitoring sites, aufeis, ice core locations, time lapse photography tripod and the location of the headwater and outlet meteorological towers. Sampling features not to scale.

The stage-discharge relationship is accurate during open water conditions yet during the early stages of melt, when stream flow was beneath the channel ice, a salt dilution method was used to determine discharge (Dingman, 2002). This method involved measuring specific conductance 25 meters downstream from the input of a $50 \mathrm{~g} \mathrm{~L}^{-1}$ sodium chloride $(\mathrm{NaCl})$ solution. Specific conductance was measured every 5 seconds in order to obtain a breakthrough curve which was then used to determine velocity and discharge values. The salt dilution method was used twice a day, once in the morning and once in the evening. Salt dilutions were continued following open water conditions in order to compare the results with those obtained using the stage-discharge measurements. Intermittent current metering 
was also conducted in order to further verify results. Current metering was conducted with a Swoffer Model 2100 current meter and by applying the velocity-area method (Dingman, 2002).

Two additional discharge monitoring sites were initiated further upstream once the stream could be located. These discharge monitoring sites were named Location B and Location C respectively. Location B was located directly below the aufeis feature (see Figure 3.5 for a visual representation of their geographic locations). Discharge at these sites was measured using the salt dilution method once every three days. A Unidata Starflow ultrasonic current meter was also installed on 29 May at Location B in order to provide a continuous discharge record for this location.

\subsubsection{Meteorological monitoring stations}

Three meteorological stations are operated and maintained within Granger Basin, two of which were used for this study (Figure 3.5). The main parameters of interest for this study were air temperature, net radiation, relative humidity, precipitation and wind speed. In addition to these three meteorological stations there is a meteorological station at the Whitehorse International Airport, 15 kilometers away, which provides detailed long-term data sets.

\subsubsection{Water quality parameters}

Continuous measurements of water quality parameters were taken at Location B and at the outlet of Granger Basin (Figure 3.5) using Hydrolab Datasonde automated water quality sensors. Each sonde was equipped with temperature, $\mathrm{pH}$, specific conductance and 
dissolved oxygen sensors. The accuracy of the various sensors are: temperature $\pm 0.10^{\circ} \mathrm{C}$, $\mathrm{DO} \pm 0.6 \mathrm{mg} \mathrm{L}^{-1}$, conductivity $\pm 0.001 \mathrm{mS} / \mathrm{cm}$, and $\mathrm{pH}$ meter \pm 0.2 units. Measurements were taken every 15 minutes throughout the study period and were recorded to a Campbell Scientific CR10X data logger.

\subsubsection{Water sampling}

A total of 185 samples (122 stream, 37 snow and 26 ice) were collected throughout the study period. Stream water samples were collected once a day in $60 \mathrm{~mL}$ air-tight plastic bottles, ensuring that there was minimal headspace. Upstream water samples were collected at Location B once a day using an ISCO automatic water sampler. Water samples were also collected at Location $\mathrm{A}$ and $\mathrm{C}$ every three days throughout the sample period. Snow and ice samples were collected, melted, filtered and transferred into $60 \mathrm{~mL}$ air-tight bottles, again ensuring that there was minimal headspace. The samples were shipped to the Cold Regions Hydrology Lab at Carleton University and underwent isotopic analysis at the GG Hatch Stable Isotope Laboratory at Ottawa University in August 2008. Ion analysis took place at the Water Chemistry Laboratory at the University of Toronto throughout February 2009.

Snow core samples were collected, melted, bottled and shipped throughout the study period. Three large snow pits were also sampled every three days by extracting a known volume of snow $\left(143 \mathrm{~cm}^{3}\right)$ at $10 \mathrm{~cm}$ intervals throughout the depth profile. These samples were weighed (in order to determine the snow density), melted, bottled and shipped. Three snow lysimeters $\left(50 \mathrm{~cm}^{2}\right)$ were also installed in order to collect the snowpack meltwater. This water was sampled weekly, bottled and shipped. 
Soil water and shallow groundwater samples collected in 2006 were used to estimate an average soil water hydrochemical and isotopic signature. They were collected from suction lysimeters and shallow wells within Granger Basin.

\subsubsection{Snow surveys}

Comprehensive snow surveys were conducted throughout the basin for the duration of the study period. Initial pre-melt snow surveys provide information regarding basin wide snow accumulation, spatial distribution, melt rates and snow water equivalent (SWE). A total of 8 transects (T1-T8) were maintained throughout the study area every 3 days in order to obtain accurate SWE and meltrate values (Figure 3.5). Transects began at the headwater with T1 and ended at the outlet with T8. Transect lengths varied as follows: $\mathrm{T} 1=60 \mathrm{~m}, \mathrm{~T} 2$ $=48 \mathrm{~m}, \mathrm{~T} 3=45 \mathrm{~m}, \mathrm{~T} 4=51 \mathrm{~m}, \mathrm{~T} 5=48 \mathrm{~m}, \mathrm{~T} 6=27 \mathrm{~m}, \mathrm{~T} 7=42 \mathrm{~m}$ and $\mathrm{T} 8=410 \mathrm{~m}$. Snow depth was measured along each transect using a G3 $240 \mathrm{~cm}$ Avalanche Tech Probe every 3-5 meters. Snow water equivalent was measured every five sample points using a Mount Rose snow corer with a calibrated scale. Snow density measurements were also taken from snow pit snow samples as explained above. In order to estimate basin wide SWE a linear relationship was established between mean depth and density for each transect via leastsquares regression analysis.

The basin was divided into three distinct snowmelt contributing areas based on elevation and vegetation. The highest elevation area (Contributing Area 1) begins at the headwater and descends downstream to Location B and represents $41 \%$ of the total basin area $\left(3.1 \mathrm{~km}^{2}\right) . \mathrm{T} 1, \mathrm{~T} 2, \mathrm{~T} 3$, and T4 are located in Contributing Area 1. Contributing Area 2 is the smallest of the three areas $\left(1 \mathrm{~km}^{2}\right)$ and represents $13 \%$ of the total area. It extends 
downstream from Location B to Location C. Transects 5 and 6 are located in Contributing Area 2. The final area, Contributing Area 3, is the largest $\left(3.5 \mathrm{~km}^{2}\right)$ and represents $46 \%$ of the total basin area. Transects $\mathrm{T} 7$ and $\mathrm{T} 8$ are found within this lower elevation contributing area which begins at Location $\mathrm{C}$ and extends downstream to the outlet of Granger Basin.

\subsubsection{Aufeis and Channel Ice}

Aufeis and channel ice were surveyed using a handheld Trimble differential global positioning system in conjunction with surveying stakes and large tape measure. This enabled the determination of total surface area of aufeis. Channel ice surface area was determined using the total length of the stream and a calculated average for stream width.

At the onset of the study period prior to any melt, 8 randomly distributed ice cores were extracted from the aufeis feature using a hand auger (Figure 3.5). This was done in order to obtain statistically representative hydrochemical and isotopic signatures for the aufeis feature. These samples were melted, bottled and shipped for storage at the Cold Regions Hydrology Lab at Carleton University.

\subsubsection{Time lapse photography}

Ground based time lapse photographs were taken every 3 days using a Canon Power Shot S5IS 8.0 Mega Pixel digital Camera mounted on a permanent tripod (Figure 3.5). 


\subsection{Laboratory Methods}

\subsubsection{Stable isotope analysis}

Water samples were analyzed for isotopes of hydrogen $\left(\delta^{2} \mathrm{H}\right)$ and oxygen $\left(\delta^{18} \mathrm{O}\right)$ in the GG Hatch Stable Isotope Laboratory at the University of Ottawa. The hydrogen isotopes in the sample water $\left(\delta^{2} \mathrm{H}\right)$ were determined using a Finnigan MAT Delta plus XP + Gasbench isotope ratio mass spectrometer. Approximately $0.6 \mathrm{~mL}$ of water was placed into an Exetainer vial and platinum catalyst pellets were added to the sample. The vials were then flushed and filled with a mixture of $2 \%$ hydrogen in helium gas. The hydrogen gas was analyzed automatically in continuous flow. The results were normalized to V-SMOW. The analytical precision for the $\delta^{2} \mathrm{H}$ analysis was $\pm 1.5 \%$.

The oxygen isotopic composition of water was determined using $0.6 \mathrm{~mL}$ of water and a gas mixture of $2 \% \mathrm{CO}_{2}$ in helium at $25^{\circ} \mathrm{C}$. No addition of catalyst pellets is used for the determination of $\delta^{18} \mathrm{O}$. The $\mathrm{CO}_{2}$ gas was analyzed on the same Finnigan MAT Delta plus XP + Gasbench. The $\mathrm{CO}_{2}$-water fractionation factor for $25^{\circ} \mathrm{C}$ is 1.0412 . The analytical precision for the $\delta^{18} \mathrm{O}$ analysis is $\pm 0.10 \%$.

\subsubsection{Major ion analysis}

All water samples were analyzed for standard cations and anions using a DIONEX LC25 chromatography oven and CD20 conductivity detector in the Water Chemistry Laboratory at University of Toronto. Samples were prepared with $0.2 \mu \mathrm{m}$ of filtered sample water. For every sixteen samples there was one replicate, one blank, and one level standard check. The detection system required $20 \mathrm{mM}$ of eluent made up of 1.0 M MSA methanesulphonic acid and carrier liquid. The anions evaluated include: chloride $(\mathrm{Cl})$, bromide $(\mathrm{Br})$, 
nitrate $\left(\mathrm{NO}_{3}{ }^{3}\right)$, phosphate $\left(\mathrm{PO}_{4}{ }^{3}\right)$ and sulphate $\left(\mathrm{SO}_{4}{ }^{2}\right)$. The cations evaluated include:

sodium $\left(\mathrm{Na}^{+}\right)$, ammonium $\left(\mathrm{NH}_{4}^{2+}\right)$, potassium $\left(\mathrm{K}^{+}\right)$, magnesium $\left(\mathrm{Mg}^{+}\right)$, and calcium $\left(\mathrm{Ca}^{+}\right)$.

The analytical detection limit for both anions and cations was $\pm 0.04 \mathrm{ppm}$. 


\section{RESULTS}

\subsection{Field Observations}

The spring melt period in Granger Basin began at the end of April 2008, following over six months of continuous snow cover. The data presented in this section relates to the study period of 10 April to 8 July, 2008.

\subsubsection{Climate}

Figure 4.1 depicts the mean daily values of air temperature, precipitation and solar radiation for the period between 10 April and 8 July. Air temperature was recorded at both the outlet and the headwater of the stream throughout the study period (Figure 4.1a). On average, the outlet temperatures were $1.0^{\circ} \mathrm{C}$ warmer than the headwater temperatures. Daily mean air temperatures began to increase beginning on 17 May and continued to rise until they peaked on 25 May. The highest temperature for both the outlet and headwater was observed on 25 May at $14.1^{\circ} \mathrm{C}$ and $12.7^{\circ} \mathrm{C}$, respectively. The maximum recorded temperatures corresponded with peak discharge and snowmelt rates. This period of high temperature was followed by a decrease, reaching a low on 9 June of $0.1^{\circ} \mathrm{C}$ at the outlet and $-0.7^{\circ} \mathrm{C}$ at the headwater. This relatively cold period was followed by rising temperatures that reached $13.2^{\circ} \mathrm{C}$ and $12.0^{\circ} \mathrm{C}$ on 3 July at both the outlet and headwater, respectively.

Net radiation was recorded at the outlet meteorological station throughout the study period (Figure 4.1b). A period of high net radiation values was observed between 22 May and 28 May. The highest daily average net radiation value was recorded on 24 May at 198 $\mathrm{W} / \mathrm{m}^{2}$. This peak period also corresponded with high temperatures, clear skies, peak discharge and increased snowmelt rates. 
Precipitation (both rain and snow) was recorded by a Nipher total gauge located $\sim 3$ $\mathrm{km}$ from the basin outlet (Figure 4.1c). Two snowfall events measuring $7.1 \mathrm{~mm}$ and $9.5 \mathrm{~mm}$ were recorded on 30 April and 10 June, respectively. The largest precipitation event of the study period was $10.8 \mathrm{~mm}$ and it took place as rain throughout the day on 19 June. In total, $67.6 \mathrm{~mm}$ of precipitation fell during the study period.

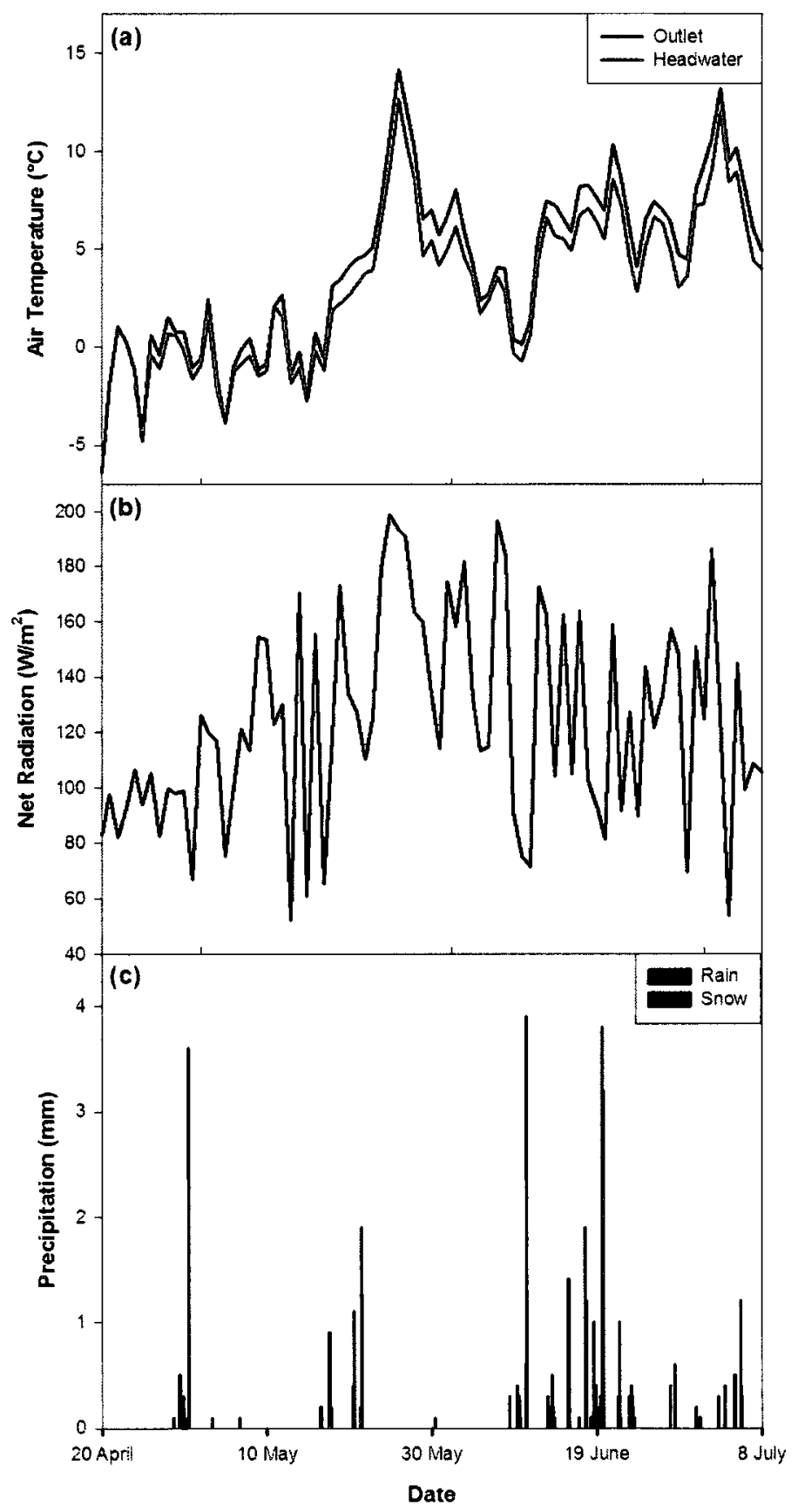

Figure 4.1. (a) Daily mean air temperature, (b) daily net radiation, and (c) total precipitation. 


\subsubsection{Discharge}

Stream discharge measurements began on 11 April, prior to the beginning of snowmelt, and continued throughout the study period. The salt dilution method was used from 11 April to 25 May. After 25 May the channel became snow and ice-free, allowing the use of a stage-discharge relationship to calculate discharge. A baseflow value of $\sim 0.01 \mathrm{~m}^{3} \mathrm{~s}^{-1}$ was recorded at the beginning of the study period. Subsequently, there was a distinct period of high flow between 23 May and 29 May, which is attributed to a period of high temperature and enhanced snowmelt (Figure 4.2).

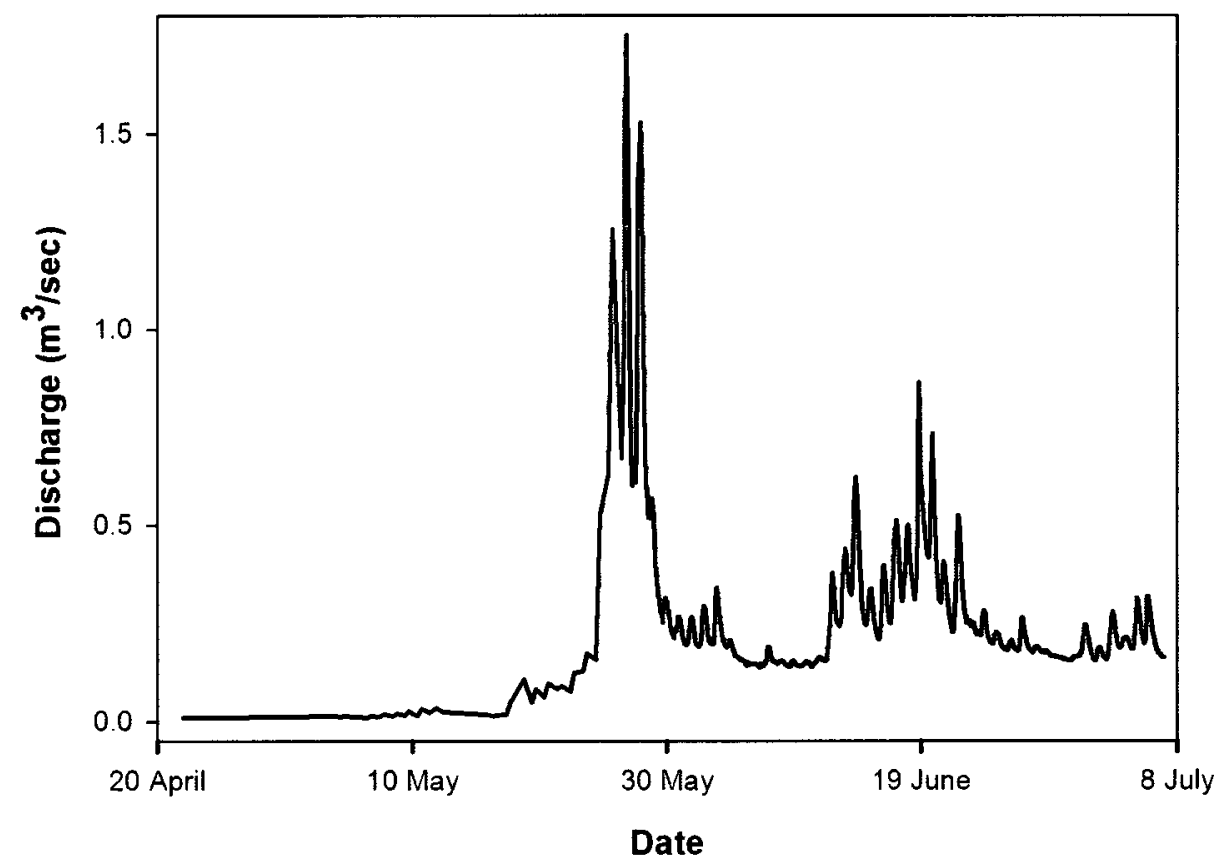

Figure 4.2. Granger Basin hydrograph throughout the snowmelt period.

Peak discharge was observed on 26 May at $1.75 \mathrm{~m}^{3} \mathrm{~s}^{-1}$. This high flow period was followed by a steady decline in discharge to a rate of $\sim 0.15 \mathrm{~m}^{3} \mathrm{~s}^{-1}$. Throughout this decline, diurnal discharge cycles associated with daily snowmelt patterns are prominent. A secondary high flow period occurred between 11 June and 21 June, which coincides with a large period of precipitation (both snow and rain). Smaller increases in flow occur later in the study 
period due to small intermittent precipitation events. Discharge was approximately $0.1-0.2$ $\mathrm{m}^{3} \mathrm{~s}^{-1}$ at the end of the period of investigation.

\subsubsection{Snow}

Comprehensive snow surveys were conducted throughout the basin along 8 transects (T1-T8). Initial snow water equivalent (SWE) values were greatest along T4, T5 and T6

(Figure 4.3a). All transects experienced a large decline in SWE between 20 May and 1 June (Figure 4.3a), which corresponds well with high temperatures and peak discharge rates. Snowmelt first began on south facing slopes and at lower elevations and became rapid following rising temperatures on 17 May.

Snow covered area (SCA) experienced a similar decline to SWE between 20 May and 1 June (Figure 4.3b). T8, nearest to the outlet, exhibited an early decline in SCA relative to the other transects due in part to its lower elevation and higher temperatures. T7 was the next transect to experience decreased SCA and the first to reach $0 \%$ SCA on 29 May. T6 and T1 were next to reach $0 \%$ SCA on 4 June and 15 June respectively. The remainder of the transects approached $0 \%$ SCA at approximately the same time, around 7 July.

Daily snowmelt rates were calculated using the change in SWE observed along each of the 8 snow transects. Area-weighted averages were applied to each of the three contributing areas outlined in section 3.2.5 (Figure 4.4) and an average snowmelt rate for the entire basin was calculated (Figure 4.5). 


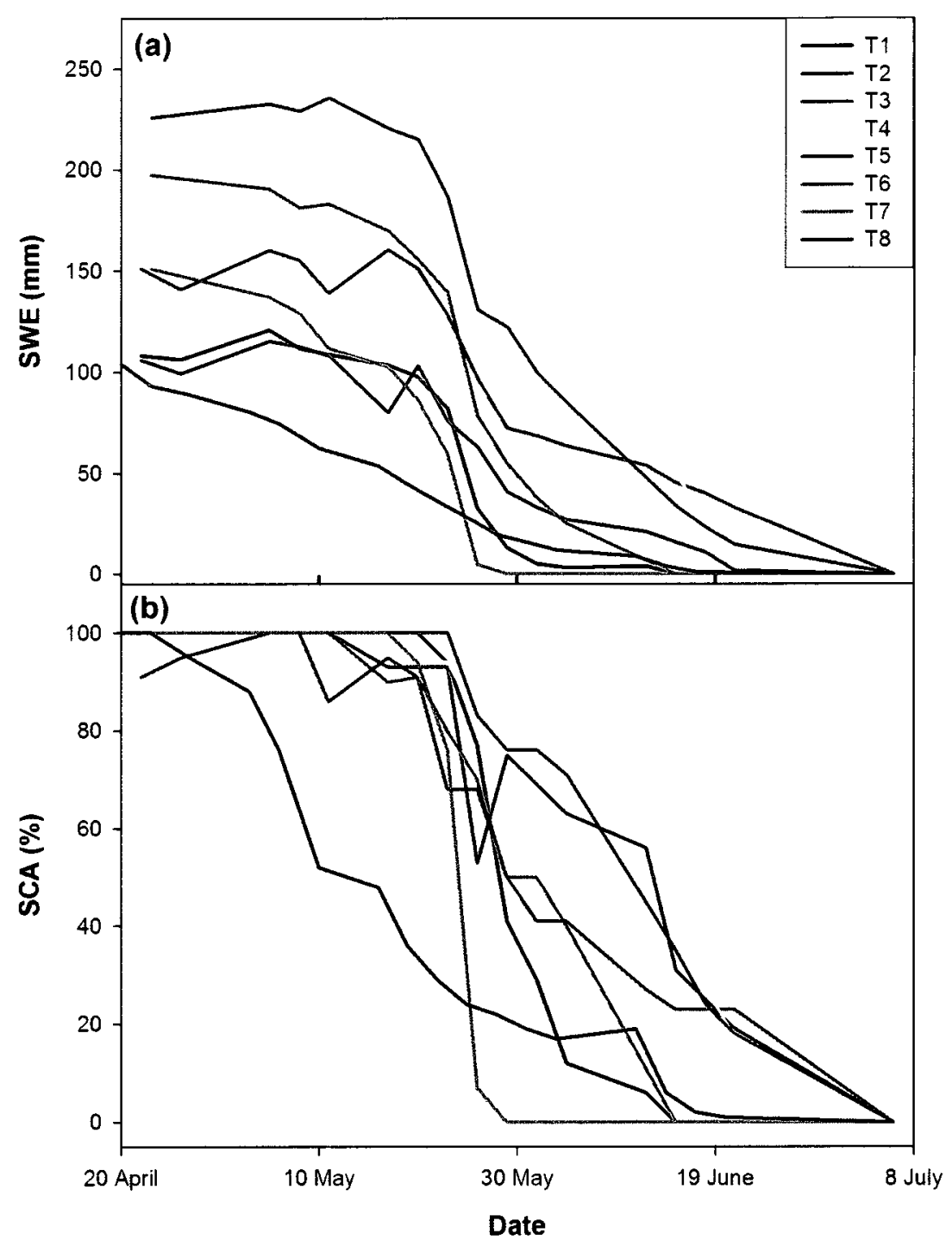

Figure 4.3. (a) Snow water equivalent (SWE), and (b) snow covered area (SCA) for all 8 snow transects.

All three contributing areas had peak snowmelt rates around 26 May, coinciding with a period of high flows. Contributing Area 2 had the highest meltrates, yet was also the smallest area contributing to runoff. Meltrates from each area were weighted based on the percent of total basin area they represented, resulting in snowmelt from Contributing Area 1 being the largest, followed by Contributing Area 3 and then finally Contributing Area 2. The 
total amount of snowmelt (in millimeters and percent) from each contributing area is presented in Table 4.1.

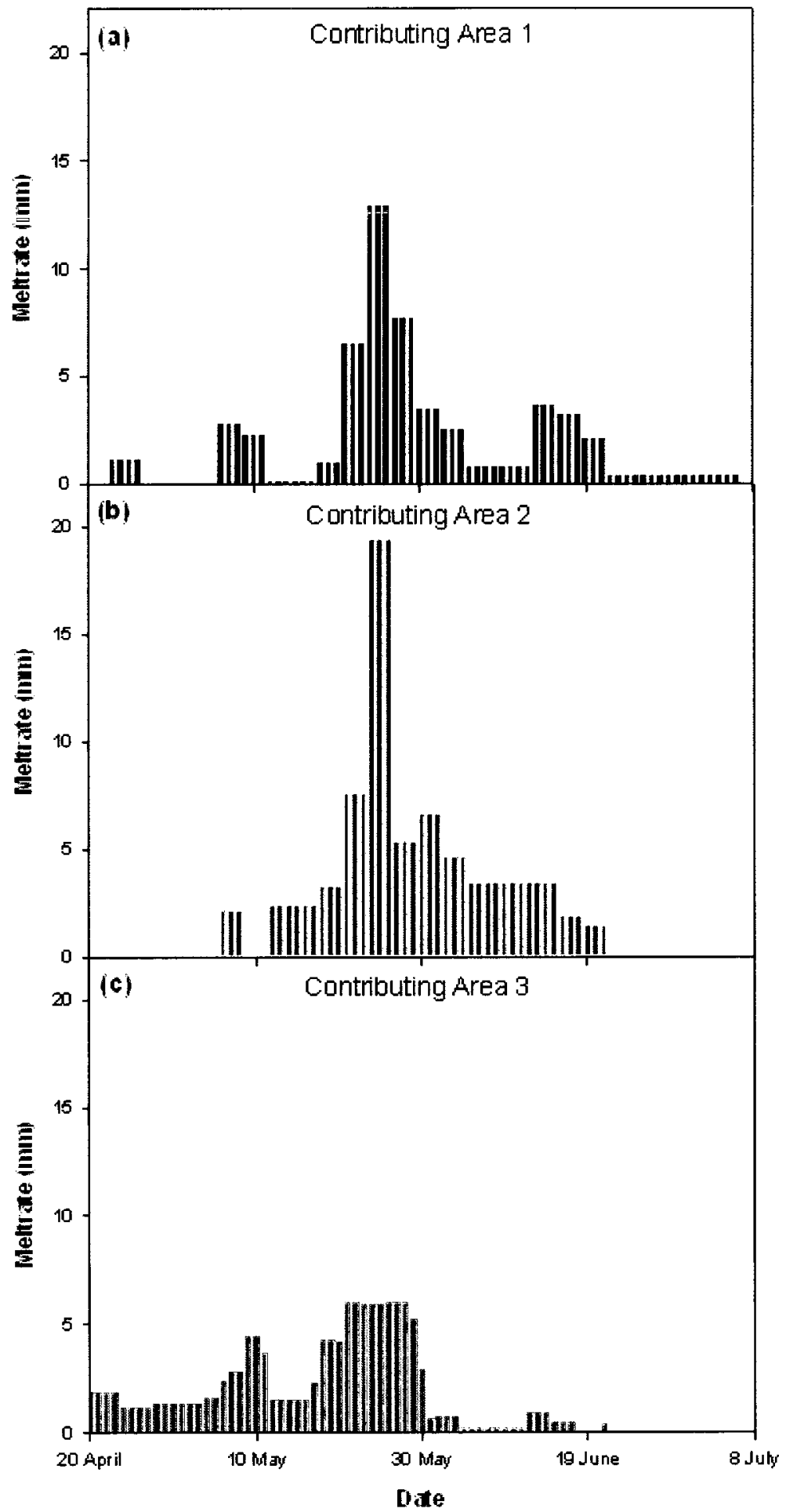

Figure 4.4. Average daily snowmelt rates for (a) Contributing Area 1 (black), (b) Contributing Area 2 (grey) and (c) Contributing Area 3 (dark grey). 


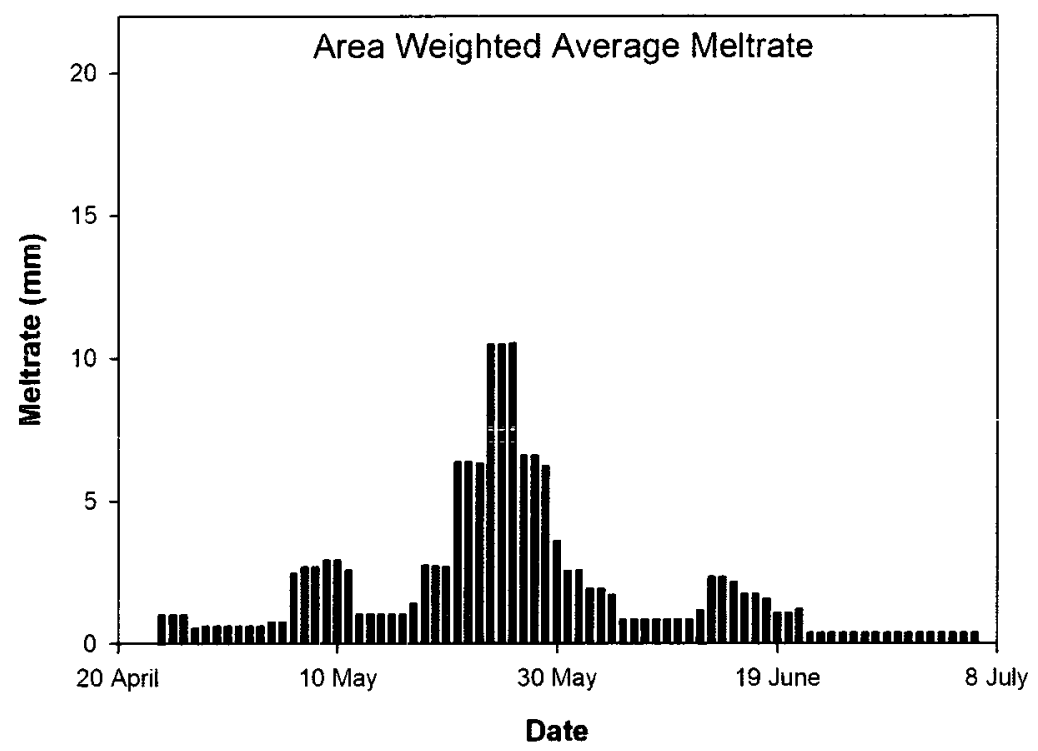

Figure 4.5. Area weighted average snowmelt rate for the entire Granger Basin Catchment.

Table 4.1. Total amount of snowmelt from each of the three contributing areas and the percent of snowmelt input this represents.

\begin{tabular}{lcc}
\hline Contributing Area & $\begin{array}{c}\text { Area Weighted Average Snowmelt } \\
(\mathbf{m m})\end{array}$ & $\begin{array}{c}\text { Percent of Total Snowmelt Input } \\
(\%)\end{array}$ \\
\hline Contributing Area 1 & 68 & 44 \\
Contributing Area 2 & 28 & 19 \\
Contributing Area 3 & 56 & 37 \\
\hline Total & 152 & 100 \\
\hline
\end{tabular}

\subsection{Water Balance}

Daily water balance components (discharge, evaporation, precipitation and SWE) were calculated for the duration of the snowmelt period. The snowmelt water balance equation in this study is defined as:

$$
P+M-Q-E=\Delta S
$$

where $P$ is precipitation, $M$ is snowmelt, $Q$ is discharge, $E$ is evaporation and $\Delta S$ is the change in all forms of storage within the basin. The calculated water balance components and the runoff ratio (the fraction of total runoff to SWE + precipitation) are shown in

\section{Table 4.2.}


Table 4.2. Granger Basin outlet water balance components and runoff ratio.

\begin{tabular}{cccccc}
\hline $\begin{array}{c}\text { SWE } \\
(\mathrm{mm})\end{array}$ & $\begin{array}{c}\text { Precipitation } \\
(\mathrm{mm})\end{array}$ & $\begin{array}{c}\text { Evaporation } \\
(\mathrm{mm})\end{array}$ & $\begin{array}{c}\text { Discharge } \\
(\mathrm{mm})\end{array}$ & $\begin{array}{c}\text { Change in Storage } \\
(\mathrm{mm})\end{array}$ & Runoff Ratio \\
\hline 152 & 68 & 88 & 173 & -41 & 0.79 \\
\hline
\end{tabular}

Daily discharge, precipitation and SWE values were calculated based on the data and methods described in sections 4.1.1, 4.1.2 and 4.1.3. Change in storage was calculated as a residual of the water balance equation. Daily evaporation was determined using a modified Priestley and Taylor approach outlined in section 2.3. An evaporation value of $0.2 \mathrm{~mm} /$ day (Pomeroy et al., 2003) was applied to snow covered areas and bare ground evaporation values were calculated using the Priestley and Taylor approach. A value of 1.26 was used for $\alpha$ based on values used in previous northern studies (Stewart and Rouse, 1977; Roulet and Woo, 1986; McCartney et al., 2006).

Evaporation was assumed to be very low $(0.2 \mathrm{~mm} /$ day $)$ when the basin was $100 \%$ snow covered and gradually increased as snowmelt proceeded and more bare ground became exposed and tundra vegetation began to grow (Figure 4.6). Maximum daily evaporation occurred on 2 July, which coincided with the second highest temperatures observed during the study period. Evaporation was second only to discharge in terms of water loss, which is characteristic of catchments underlain by permafrost (Woo, 1986). 


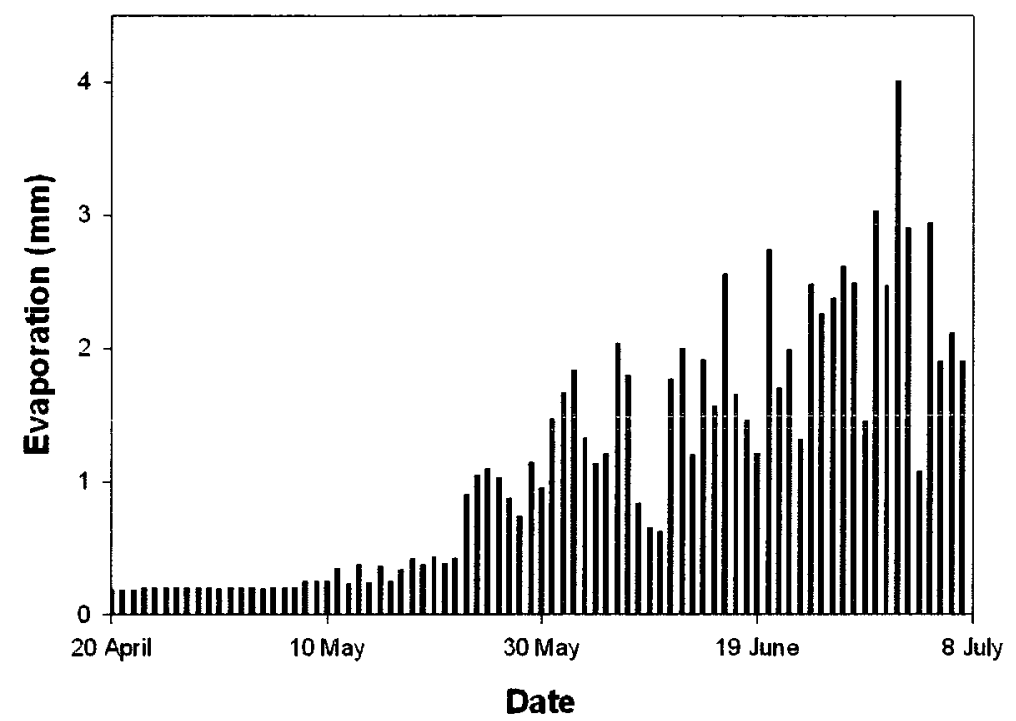

Figure 4.6. Granger Basin total daily evaporation.

The cumulative values of the daily water balance components are shown in Figure

4.7. Snowmelt is the largest source of water to the system, and discharge the largest loss.

The change in storage is initially a net gain of water during the peak snowmelt period as soil moisture is recharged, and becomes a loss in the later stages of the study period as evaporation draws water from the soil and runoff is transferred to the stream.

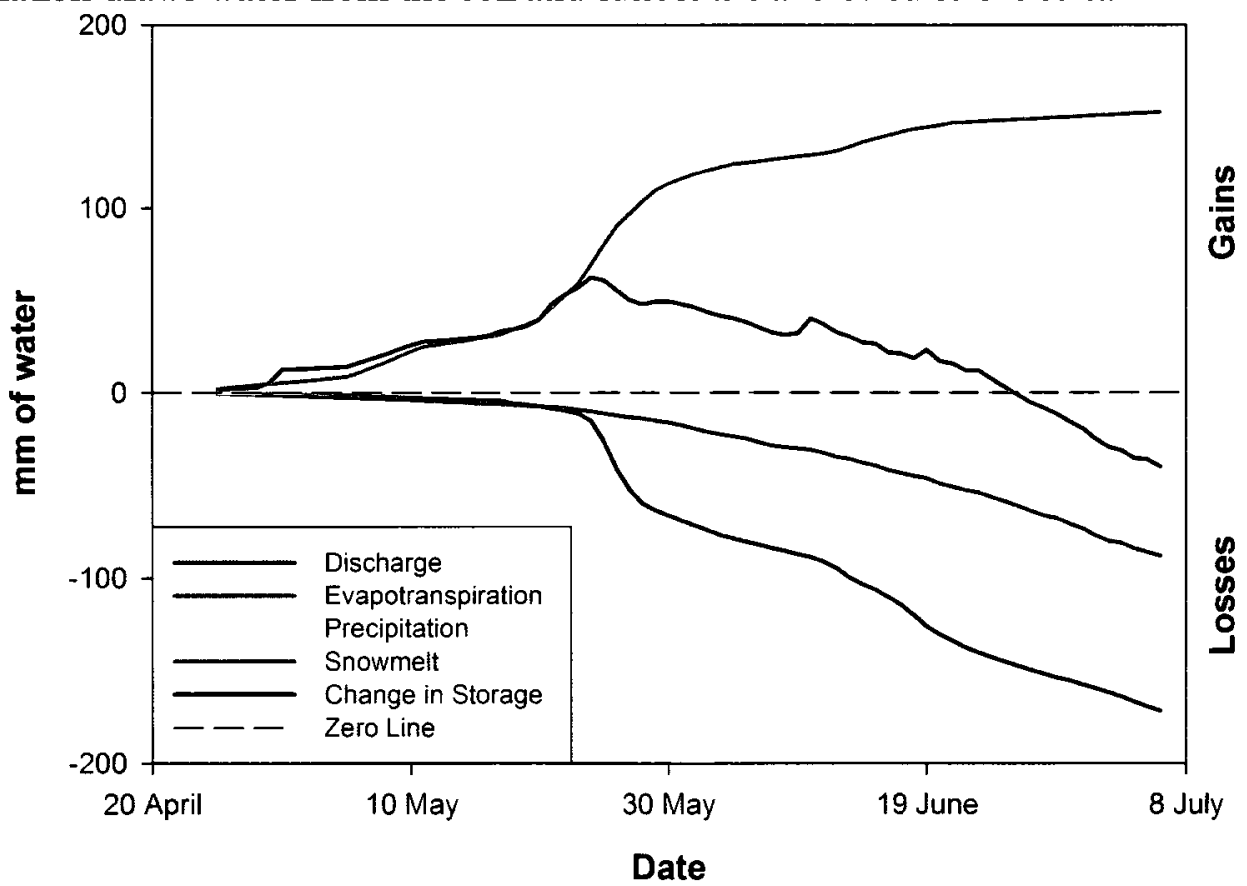

Figure 4.7. Cumulative daily water balance components. 


\subsection{Hydrograph Separations}

Two-component hydrograph separations were performed based on the steady state mass balance equations (2-9 and 2-10) for water and each specific conservative tracer (Sklash and Farvolden, 1979). Several tracers are known to act conservatively (Obradovic and Sklash, 1986) although in this study only $\delta^{18} \mathrm{O}$ and $\delta^{2} \mathrm{H}$ had distinct signatures that provided comparable hydrograph separation results (Figure 4.8 and Figure 4.9).

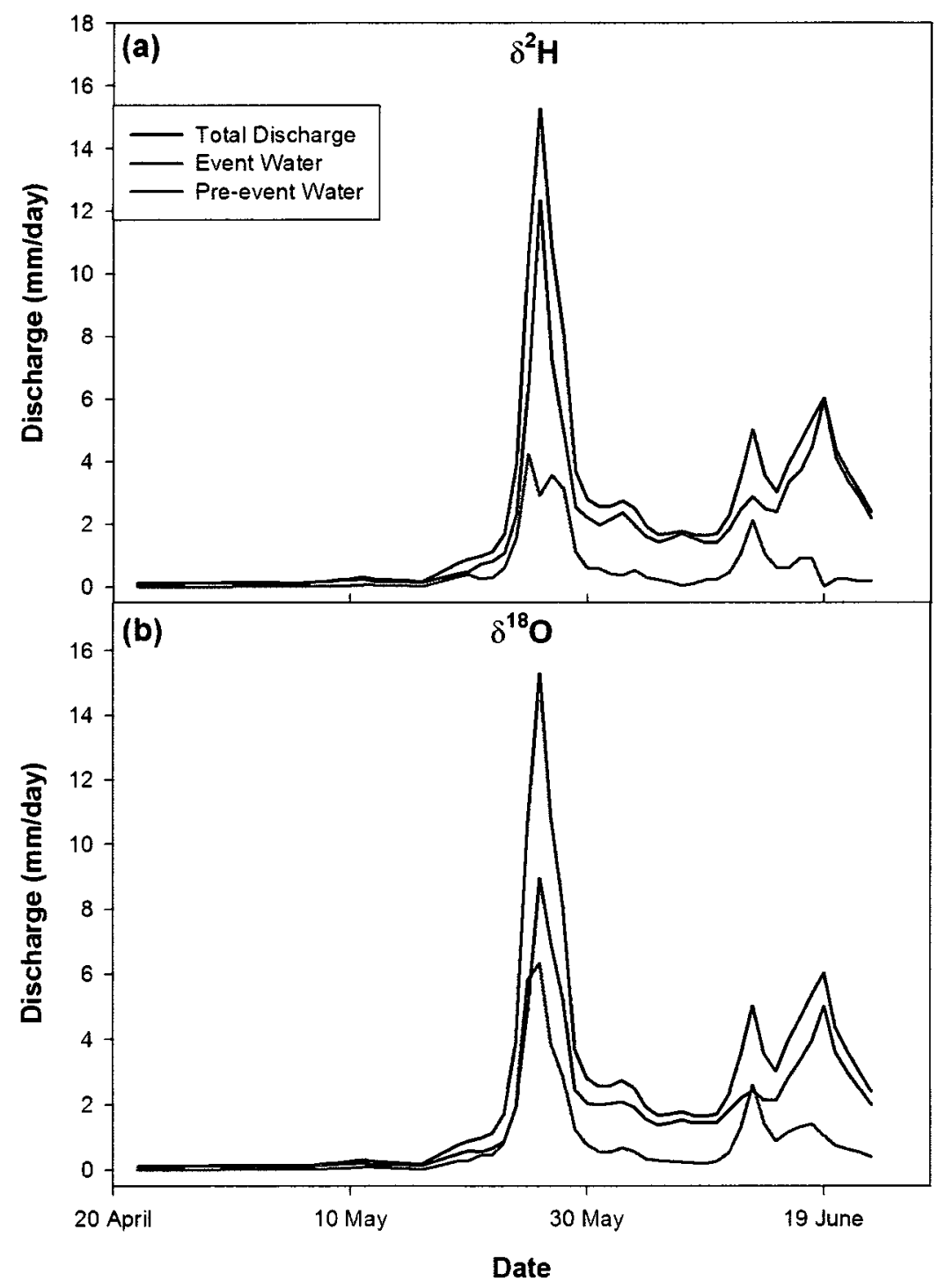

Figure 4.8. Isotope hydrograph separations using (a) $\delta^{2} \mathrm{H}$ and (b) $\delta^{18} \mathrm{O}$. 
Pre-event and event water isotope values were calculated using weighted averaging of samples. Pre-melt baseflow samples were used to estimate the pre-event isotope signature. A volume weighted mean of snow lysimeter samples and average snow core values were used to calculate the event water value. The pre-event and event water end-member values used for the hydrographs separations can be found in Table 4.3, along with the standard error associated with each component.

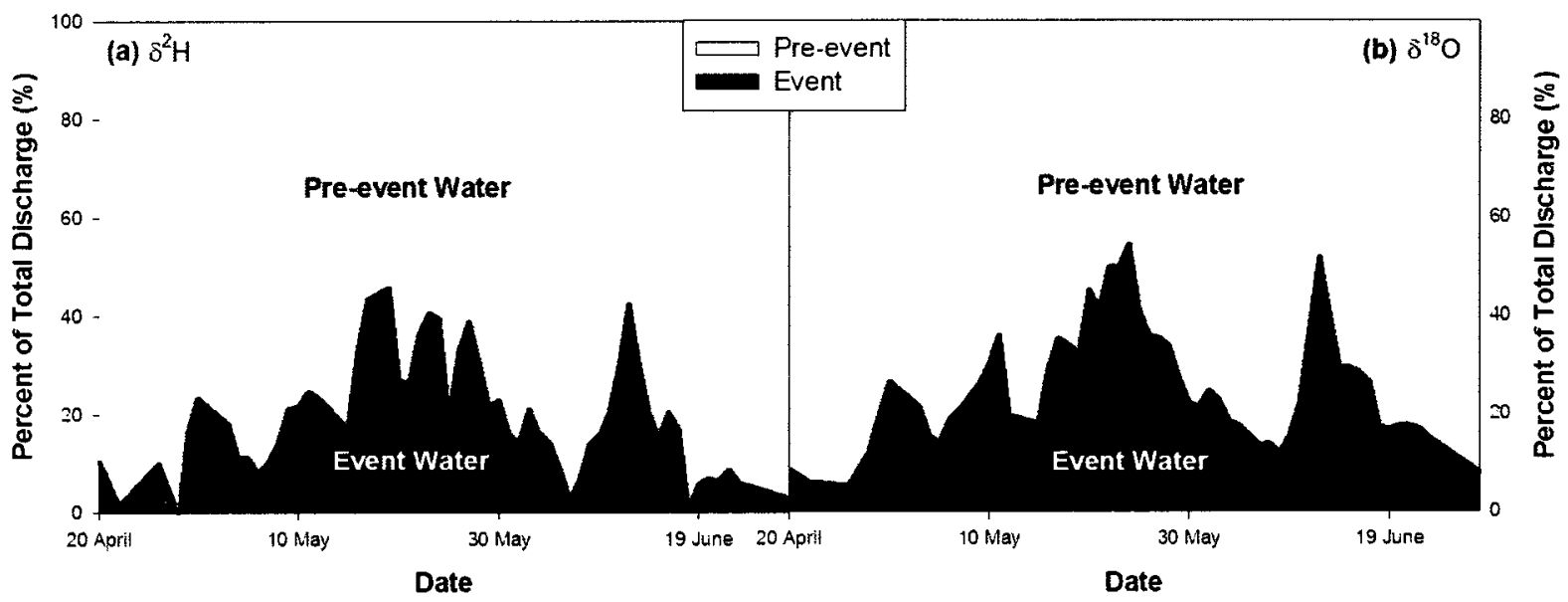

Figure 4.9. Hydrograph separation results for (a) $\delta^{18} \mathrm{O}$ and (b) $\delta^{2} \mathrm{H}$ as the event water fraction (\%) of total discharge.

Table 4.3. Pre-event and event water $\delta^{18} \mathrm{O}$ and $\delta^{2} \mathrm{H}$ values \pm standard error.

\begin{tabular}{lccc}
\hline Component & Number of Samples & $\begin{array}{c}\boldsymbol{\delta}^{18} \mathbf{O} \\
\pm\end{array}$ & $\begin{array}{c}\boldsymbol{\delta}^{\mathbf{2}} \mathbf{H} \\
\left( \pm \mathrm{S}_{\mathrm{s}}\right)\end{array}$ \\
\hline Pre-event & 3 & $-21.19 \pm 0.16$ & $-165.32 \pm 0.92$ \\
Event & 11 & $-24.18 \pm 0.65$ & $-188.12 \pm 2.52$ \\
\hline
\end{tabular}

The two-component hydrograph separation conducted using $\delta^{2} \mathrm{H}$ values determined that event water was responsible for $23 \%(40 \mathrm{~mm})$ of total discharge and pre-event water contributed $77 \%(133 \mathrm{~mm})$ of total discharge throughout the entire melt period. On the other hand, the hydrograph separation using $\delta^{18} \mathrm{O}$ values calculated that event water contributed $32 \%(55 \mathrm{~mm})$ of the total discharge and pre-event water was responsible for $68 \%(118 \mathrm{~mm})$. For the peak flow period, between 24 May and $30 \mathrm{May}, \delta^{2} \mathrm{H}$ values 
determined that pre-event water was responsible for $69 \%$ of streamflow and $\delta^{18} \mathrm{O}$ values determined that pre-event water was responsible for $59 \%$ of streamflow.

Table 4.4 Amount of pre-event and event water in both percent and water equivalent based on both $\delta^{18} \mathrm{O}$ and $\delta^{2} \mathrm{H}$.

\begin{tabular}{lccc}
\hline & Component & Percent $(\%)$ & Water Equivalent $(\mathrm{mm})$ \\
\hline$\delta^{18} \mathrm{O}$ & Pre-event & 68 & 118 \\
& Event & 32 & 55 \\
\hline$\delta^{2} \mathrm{H}$ & Pre-event & 77 & 133 \\
& Event & 23 & 40 \\
\hline
\end{tabular}

Event water contributions were highest during the peak flow period and during the high precipitation event. Based on $\delta^{2} \mathrm{H}$ values, event water reached its peak contribution on 20 May at $46 \%$ and on 24 May at $41 \%$. As a result of high precipitation, event water contribution reached $42 \%$ on 13 June. When based on $\delta^{18} \mathrm{O}$ values, event water reached its peak contribution on 25 May at $54 \%$. During the high precipitation period, $\delta^{18} \mathrm{O}$ data indicated that event water contributed a maximum of $52 \%$ on 13 June. The lowest period of event water contribution occurred on 7 June using $\delta^{2} \mathrm{H}$, at a value of $3 \%$. The lowest event water contribution based on $\delta^{18} \mathrm{O}$ was on 9 June at $12 \%$.

\subsubsection{Uncertainty Analysis}

The error associated with the hydrograph separations was evaluated using the Gaussian error propagation technique proposed by Genereux (1998); which assumes that each parameter measured is a function of several components that each has an uncertainty independent of the others. In order to estimate the uncertainty associated with pre-event water, event water and stream water values, it is important to determine the systematic and analytical errors of the tracer signatures. The Gaussian error propagation technique allows for the uncertainty of pre-event water, event water and stream water to be determined: 


$$
W_{f p e}=\sqrt{\left[\frac{c_{e}-c_{T}}{\left(c_{p}-c_{e}\right)^{2}} W_{c_{p}}\right]^{2}+\left[\frac{c_{T}-c_{p}}{\left(c_{p}-c_{T}\right)^{2}} W_{c_{e}}\right]^{2}+\left[\frac{1}{\left(c_{p}-c_{e}\right)} W_{c_{T}}\right]^{2}}
$$

where $W$ is uncertainty, $\mathrm{c}$ is the tracer concentration, $f$ is the fraction of total discharge and the subscripts $p, e$, and $T$ refer to the pre-event, event and stream water components respectively. The addition of the three parameters yields the uncertainty related to the hydrograph separation performed. Table 4.5 outlines the pre-event and event water endmember values as well as individual and total percent errors.

Table 4.5. Uncertainty for pre-event, event and streamwater components for both $\delta^{18} \mathrm{O}$ and $\delta^{2} \mathrm{H}$.

\begin{tabular}{llcc}
\hline Component & & $\boldsymbol{\delta}^{\mathbf{1 8}} \mathbf{O}$ & $\boldsymbol{\delta}^{\mathbf{2}} \mathbf{H}$ \\
\hline \multirow{2}{*}{ Pre-event } & $\mathrm{C}_{\mathrm{p}}(\%)$ & -21.19 & -165.32 \\
& $\mathrm{~W}_{\mathrm{cp}}(\%)$ & \pm 1.3 & \pm 1.0 \\
\multirow{2}{*}{ Event } & $\mathrm{C}_{\mathrm{e}}(\% \mathrm{o})$ & -24.18 & -188.12 \\
& $\mathrm{~W}_{\mathrm{ce}}(\%)$ & \pm 5.3 & \pm 4.9 \\
\multirow{2}{*}{ Total Stream } & $\mathrm{C}_{\mathrm{T}}(\% \mathrm{o})$ & Sample Value & Sample Value \\
& $\mathrm{W}_{\mathrm{cT}}(\%)$ & \pm 0.7 & $\pm 1.1-1.2$ \\
\hline \multicolumn{2}{l}{ Total Average Percent Error $(\%)$} & \pm 8.9 & \pm 2.5 \\
\multicolumn{2}{l}{ Total Percent Error Range $(\%)$} & $\pm 3.3-33.1$ & $\pm 0.2-13.4$ \\
\hline
\end{tabular}

For pre-event water $\left(C_{p}\right)$, the uncertainty $\left(W_{c p}\right)$ was calculated as the coefficient of varation of the pre-event baseflow values prior to snowmelt. The event water $\left(\mathrm{C}_{\mathrm{e}}\right)$ uncertainty $\left(\mathrm{W}_{\mathrm{ce}}\right)$ was calculated as the coefficient of variation of the snowmelt water values. Stream water uncertainty $\left(\mathrm{W}_{\mathrm{cT}}\right)$ was estimated using the analytical error associated with each isotope. The estimated average percent error for $\delta^{18} \mathrm{O}$ was $8.9 \%$ and the estimated average percent error for $\delta^{2} \mathrm{H}$ was $2.5 \%$.

On 26 April, 29 April, 7 June and 19 June the percent errors for $\delta^{2} \mathrm{H}$ stream values were $234.5 \%, 1420.8 \%, 60.5 \%$ and $1225.0 \%$, respectively. These large errors resulted when the pre-event and total streamflow $\delta^{2} \mathrm{H}$ signatures were within the range of each others standard error, resulting in extremely small denominators in the second component of 
equation 4-7. If these large error values are included, the average error for $\delta^{2} \mathrm{H}$ is $56.8 \%$ and the range is from $0.2-1420.8 \%$. These large percent errors are not observed for $\delta^{18} \mathrm{O}$.

\subsection{Aufeis, Channel Ice and Soil Water}

The average amount of water stored in the aufeis feature and in basin-wide channel ice was calculated by multiplying the volume of ice (in $\left.\mathrm{m}^{3}\right)$ by the relative density of ice $\left(\varrho_{i}=\right.$ $\left.917 \mathrm{~kg} \mathrm{~m}^{-3}\right)$. The estimated total contribution that aufeis ablation could have made to stream discharge is $0.26 \mathrm{~mm}$. This value is small relative to the total stream discharge of $173 \mathrm{~mm}$ during the study period, representing only $0.18 \%$ of total streamflow. The estimated total contribution that channel ice could have made to stream discharge is $0.77 \mathrm{~mm}$. The combined contribution of aufeis and channel ice melt to stream discharge during the study period was $1.03 \mathrm{~mm}(0.6 \%$ of total streamflow). The combined area of aufeis and channel ice was $0.02 \mathrm{~km}^{2}(0.3 \%$ of the total basin area). The values used in the calculations are presented in Table 4.6.

Table 4.6. The maximum and minimum length, width, depth, volume and water equivalent of the aufeis feature. Uncertainty is presented in $\mathrm{m}, \mathrm{m}^{3}$ and $\mathrm{mm}$.

\begin{tabular}{lccccc}
\hline Component & $\begin{array}{c}\text { Length } \\
(\mathbf{m}) \\
\pm \text { uncertainty }\end{array}$ & $\begin{array}{c}\text { Width } \\
\mathbf{( m )} \\
\pm \text { uncertainty }\end{array}$ & $\begin{array}{c}\text { Depth } \\
\mathbf{( m )} \\
\pm \text { uncertainty }\end{array}$ & $\begin{array}{c}\text { Volume } \\
\left(\mathbf{m}^{\mathbf{3}}\right) \\
\pm \text { uncertainty }\end{array}$ & $\begin{array}{c}\text { Water Equivalent } \\
(\mathbf{m m}) \\
\pm \text { uncertainty }\end{array}$ \\
\hline Aufeis & $125 \pm 25$ & $23 \pm 7$ & $0.70 \pm 0.14$ & $2012 \pm 1408$ & $0.24 \pm 0.17$ \\
Channel Ice & $3000 \pm 100$ & $4 \pm 1$ & $0.5 \pm 0.10$ & $6000 \pm 2880$ & $0.77 \pm 0.37$ \\
\hline Total & - & - & - & $8012 \pm 4288$ & $1.03 \pm 0.56$ \\
\hline
\end{tabular}

Aufeis ablation was monitored using an ablation stake. Ice ablation exhibited a linear

trend, expressed as volume over time, particularly after the early melt period (Figure 4.10).

This is characteristic of subarctic regions due to higher intensity and shorter melt periods relative to colder regions (Reedyk et al., 1995). 
The contribution of aufeis and channel ice to streamflow can also be examined based on total volumes of water. Table 4.7 shows the total volume of ice meltwater, snow meltwater, soil water and stream water as well as their water equivalent values. Soil water volume was estimated based on Quinton et al. (2005) who examined liquid moisture content of the organic soil in the active layer of Granger basin based on soil temperature, porosity and bulk density.

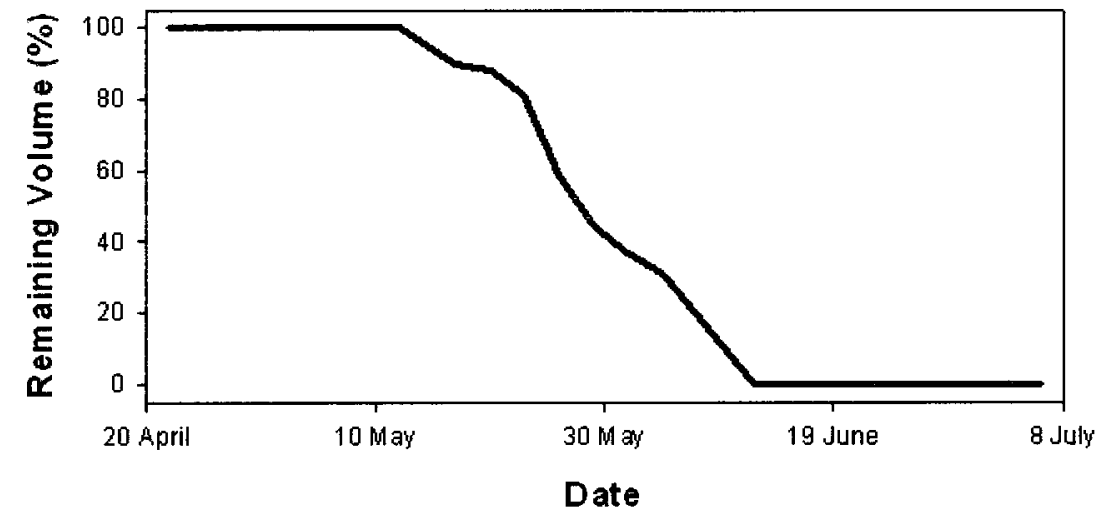

Figure 4.10. Aufeis ablation curve depicting the percent volume remaining over time.

Table 4.7. Total volume and water equivalent of basin-wide ice melt water, snowmelt water, soil water and stream water. Uncertainty is presented in $\mathrm{m}^{3}$ and $\mathrm{mm}$, respectively.

\begin{tabular}{lcc}
\hline Component & $\begin{array}{c}\text { Volume }\left(\mathbf{m}^{3}\right) \\
\pm \text { uncertainty }\end{array}$ & $\begin{array}{c}\text { Water Equivalent }(\mathbf{m m}) \\
\pm \text { uncertainty }\end{array}$ \\
\hline Ice & $8012 \pm 4288$ & $1.03 \pm 0.56$ \\
Soil & $570000 \pm 188100$ & $50 \pm 25$ \\
Snow & $1.16 \times 10^{12} \pm 2.32 \times 10^{11}$ & $153 \pm 31$ \\
Stream & $1.31 \times 10^{12} \pm 1.97 \times 10^{11}$ & $173 \pm 26$ \\
\hline
\end{tabular}

Based on the estimates outlined in Table 4.6 and Table 4.7, total basin-wide ice represents only $0.60 \%$ of the total volume of streamflow during the study period.

Conversely, water stored in the soil throughout winter and then discharged into the stream during the melt period represents up to $29 \%$ of the total volume of streamflow. If the soil water already in the basin is considered pre-event water and is displaced through the soil by snowmelt water, then it could represent up to $40 \%$ of the pre-event water contribution to streamflow (given that total pre-event water is $\sim 126 \mathrm{~mm}$ and soil water is $\sim 50 \mathrm{~mm}$ ). 


\subsection{End-Member Mixing Analysis}

Initially, a total of 36 end-member mixing diagrams (using ice, snow and groundwater as the three end-members) were conducted for all possible combinations of the 7 major ions as well as $\delta^{18} \mathrm{O}$ and $\delta^{2} \mathrm{H}$. Of these diagrams, the most applicable were the combinations of the conservative tracers chloride $(\mathrm{Cl}), \delta^{18} \mathrm{O}$ and $\delta^{2} \mathrm{H}$. The $\delta^{18} \mathrm{O}$ versus $\delta^{2} \mathrm{H}$ end member mixing diagram did not bind the stream measurements as the groundwater and ice $\delta^{18} \mathrm{O}$ and $\delta^{2} \mathrm{H}$ end-member values were too similar. Both the chloride versus $\delta^{18} \mathrm{O}$ (Figure 4.11a) and the chloride versus $\delta^{2} \mathrm{H}$ (Figure 4.11b) mixing diagrams bound the stream values well.

The end-member values for pre-event water (groundwater) and event water (snowmelt water) were calculated as outlined in section 4.3. A volume weighted mean of ice cores was used to calculate the ice end-member values.

The end-member mixing diagrams shown in Figure 4.11 provided equivocal evidence that streamflow chemistry could result from a combination of the three proposed end-members, although the stream values were not completely bounded by the end-member values. Both diagrams depict an apparent deflection of streamwater values towards the ice end-member near the beginning of the melt period, as indicated by the streamflow evolution arrows. However, the total ice meltwater contribution $(1.01 \mathrm{~mm})$, could not have contributed the quantity of water necessary to create the observed deflection. This provided evidence that a fourth potential end-member may have been overlooked. In this case, archived data from previous years indicated that the missing end-member is likely the soil water component. An estimate of the soil water end-member was calculated using archived 
soil water and shallow groundwater data from the 2006 field season (Duarte, 2007). The endmember values used for the end-member mixing diagrams are presented in Table 4.8.
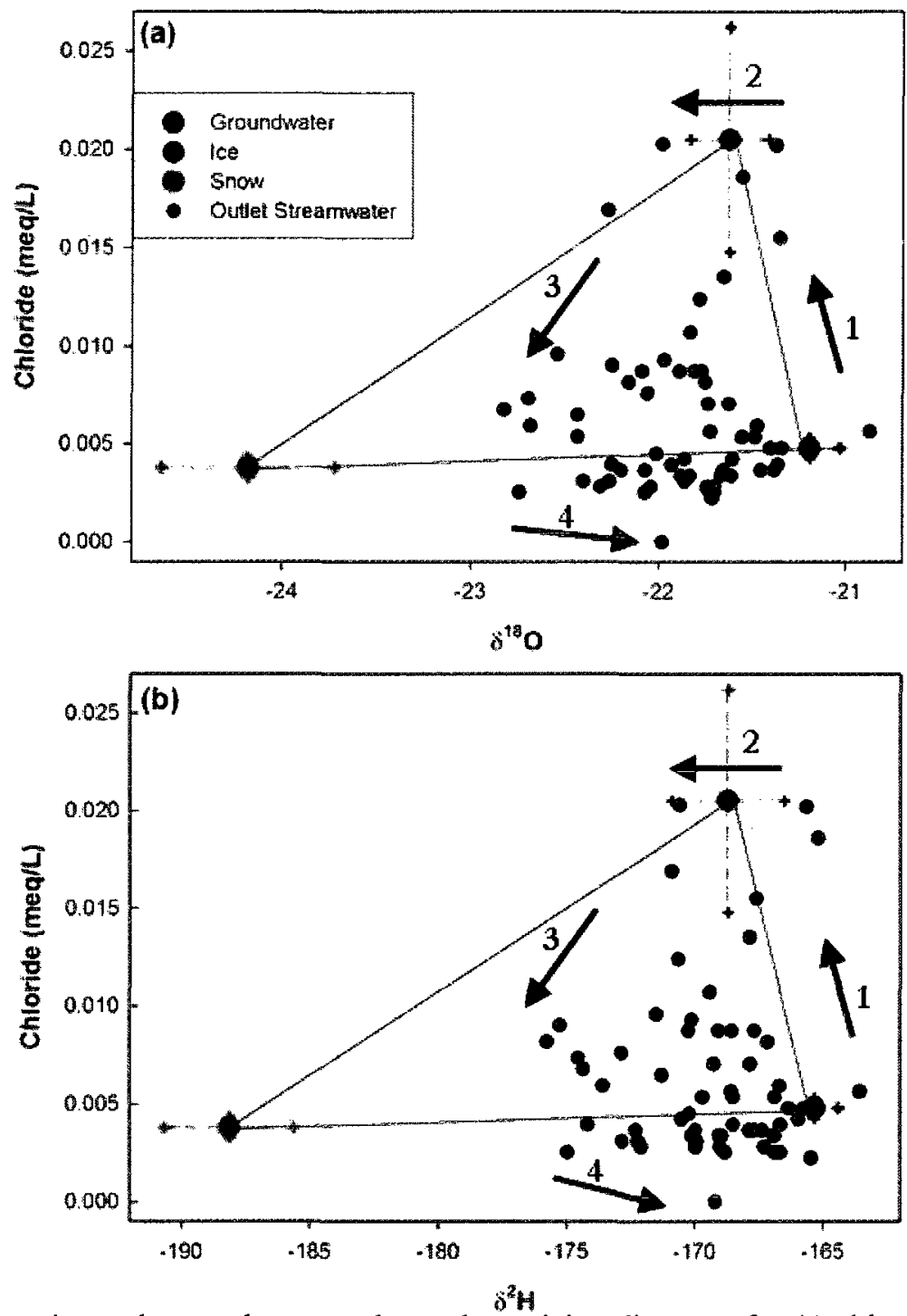

Figure 4.11. Snow, ice and groundwater end-member mixing diagrams for (a) chloride vs. $\delta^{18} \mathrm{O}$ and (b) chloride vs. $\delta^{2} \mathrm{H}$ ( \pm standard error). Arrows indicate the direction of streamflow evolution (1 being the start and 4 being the end).

Table 4.8. End-member values for $\delta^{18} \mathrm{O}, \delta^{2} \mathrm{H}$ and chloride \pm standard error.

\begin{tabular}{|c|c|c|c|}
\hline End-member & $\begin{array}{c}\delta^{18} \mathrm{O} \\
\left( \pm \mathrm{S}_{\mathbf{x}}\right)\end{array}$ & $\begin{array}{c}\delta^{2} \mathbf{H} \\
\left( \pm S_{x}\right)\end{array}$ & $\begin{array}{l}\text { Chloride } \\
\text { (meq/L) }\end{array}$ \\
\hline Groundwater & $-21.19 \pm 0.16$ & $-165.32 \pm 0.92$ & $0.0048 \pm 0.0005$ \\
\hline Ice & $-21.62 \pm 0.21$ & $-168.71 \pm 2.20$ & $0.0205 \pm 0.0057$ \\
\hline Snow & $-24.18 \pm 0.65$ & $-188.12 \pm 2.52$ & $0.0038 \pm 0.0005$ \\
\hline Soil & $-21.93 \pm 0.06$ & $-168.96 \pm 0.72$ & $0.0261 \pm 0.0098$ \\
\hline
\end{tabular}


Figure 4.12 demonstrates two end-member mixing diagrams that use the soil endmember in place of the ice end-member. The soil end-member bounded the stream values better than the ice end-member and was also a more plausible component due to its larger volume and thus larger potential to augment streamflow and contribute to stream chemistry.
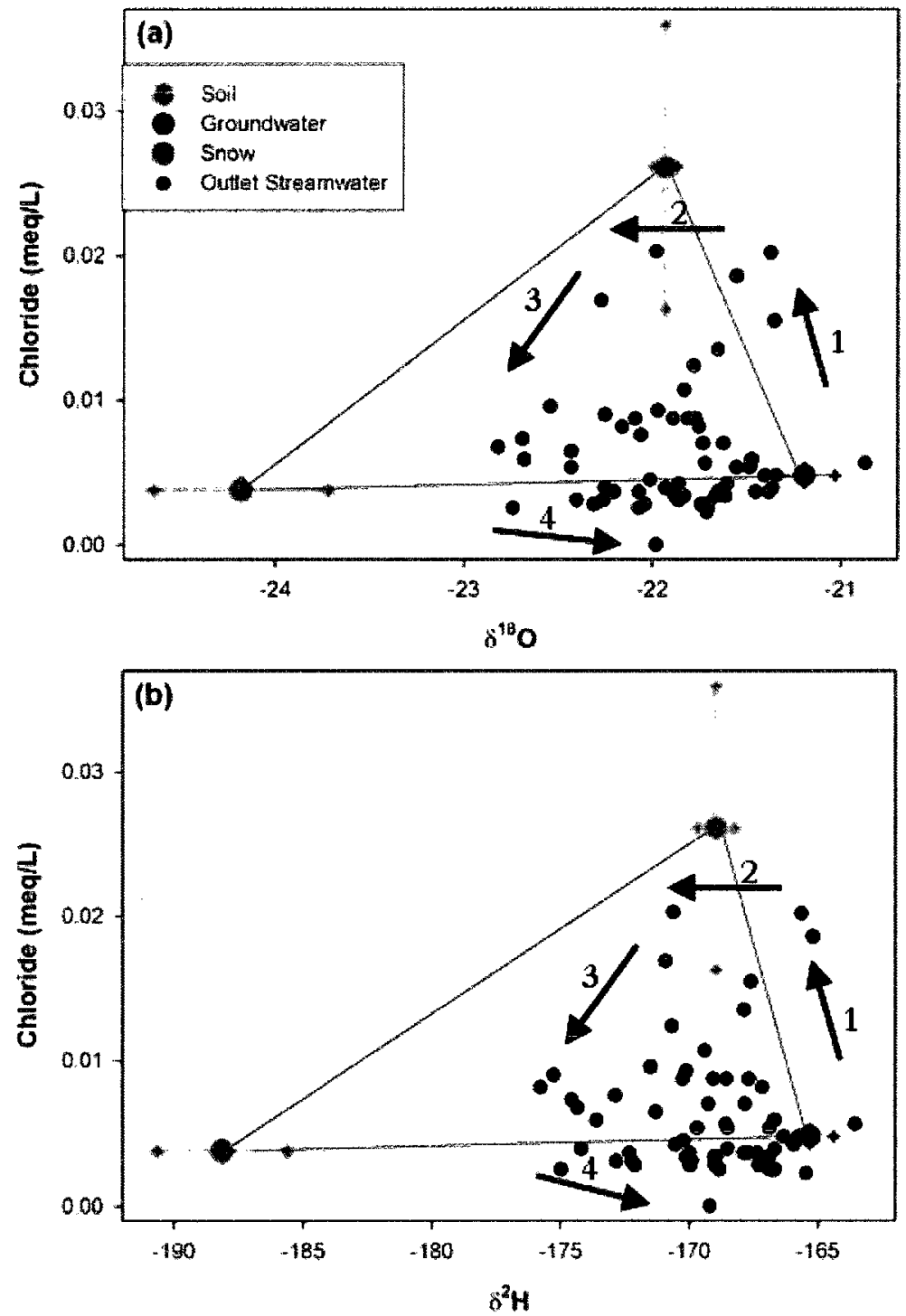

Figure 4.12. Snow, soil and groundwater end-member mixing diagrams for (a) chloride vs. $\delta^{18} \mathrm{O}$ and (b) chloride vs. $\delta^{2} \mathrm{H}$ ( \pm standard error). Arrows indicate the direction of streamflow evolution (1 being the start and 4 being the end).

The soil water end-member contributed to streamflow early in the study period, as indicated by the streamflow evolution arrows. The end-member mixing diagrams indicate that stream 
chemistry began near the groundwater signature and demonstrated an early influence from soil water followed by a later deflection towards the snowmelt water signature.

\subsection{Isotopic Observations}

The local meteoric water line (LMWL) of a region can help to evaluate where, approximately, water samples lie relative to the local precipitation values. This can serve as a tool for indicating evaporation, as the slope of the line would be less than that of the LMWL. Figure 4.13 portrays the Whitehorse LMWL and the position of the outlet, Location $\mathrm{B}$ and Location $\mathrm{C} \delta^{18} \mathrm{O}$ and $\delta^{2} \mathrm{H}$ data relative to it. The basin samples were all located on the LMWL therefore suggesting that the stream water has not undergone a great deal of evaporation as well as helping to validate the analytical results.

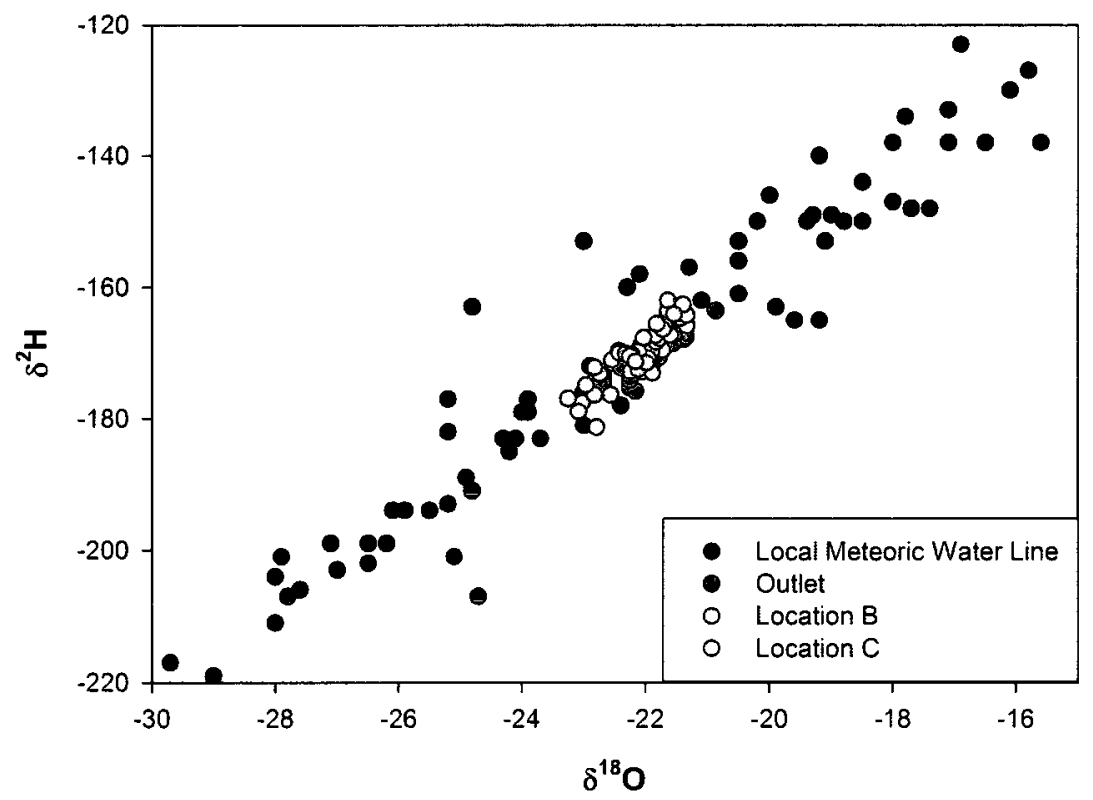

Figure 4.13. Local meteoric water line for the Whitehorse area (Birks et al., 2003). Outlet, Location B and Location $C$ streamwater values are also plotted in red, green and blue, respectively.

The stable isotopes of water $\left(\delta^{18} \mathrm{O}\right.$ and $\left.\delta^{2} \mathrm{H}\right)$ were measured daily at the outlet and every three days at Location B and Location C (Figure 4.14). As discussed in Chapter 2, 


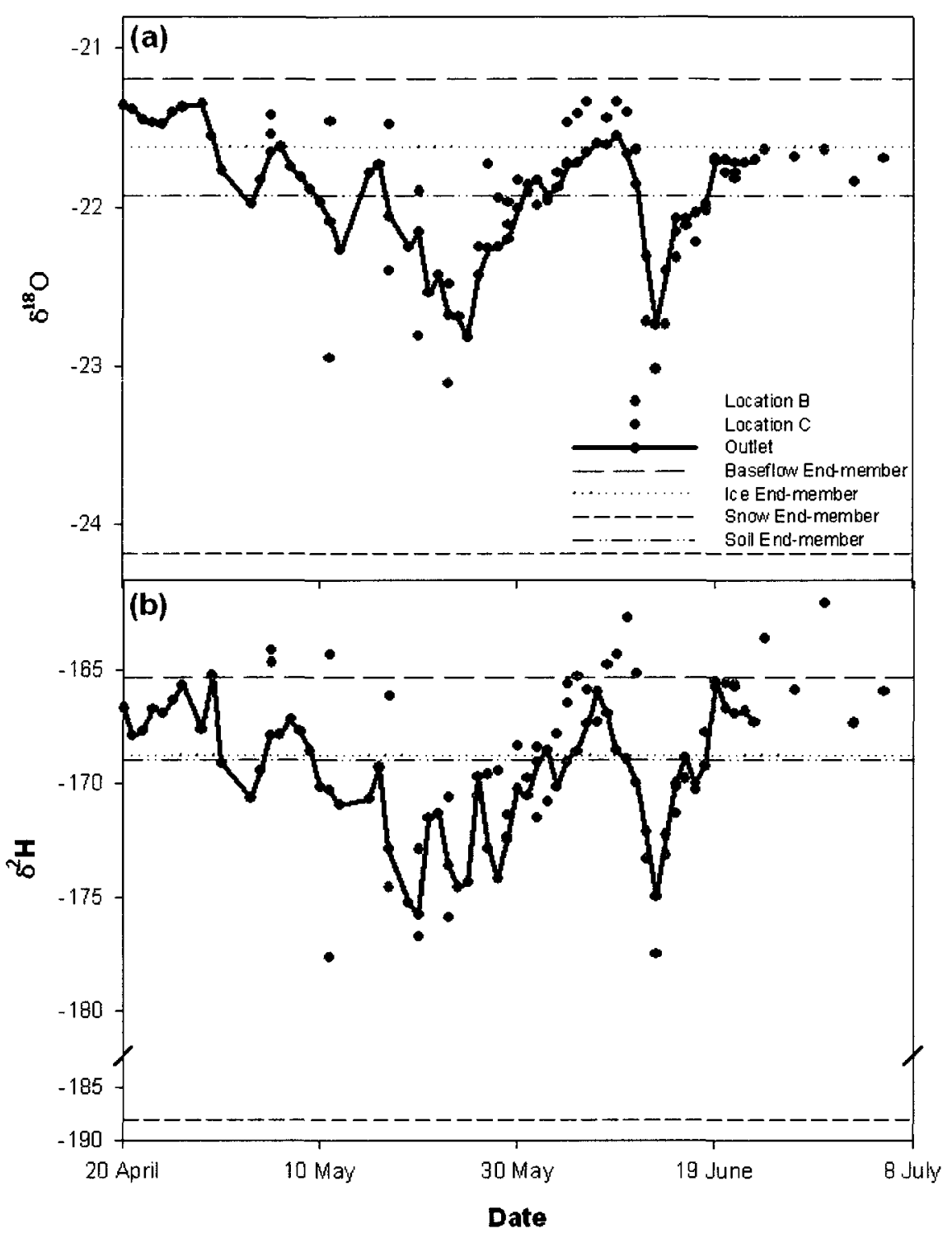

Figure 4.14. Time series of (a) $\delta^{18} \mathrm{O}$ and (b) $\delta^{2} \mathrm{H}$ observed at Location $\mathrm{B}$ (red points), and Location $\mathrm{C}$ (green points) and the outlet (blue line). The end-member values for baseflow, ice, snow and soil are also indicated on the graph by a long dashed line, dotted line, short dashed line and a dashed-dotted line respectively.

isotopes fractionate during evaporation and condensation which gives rain, snow and groundwater distinct isotopic signatures based on the amount of evaporation and condensation that has occurred (Obradovic and Sklash, 1986). This varying isotopic composition of water allows for the identification of a variety of different source waters (Hooper and Shoemaker, 1986). Snowmelt, ice-melt, soil water and groundwater were all 
contributing end-members to streamflow and the unique isotopic signature of each of these end-members is presented in Figure 4.14 and Table 4.8.

The stream values of $\delta^{18} \mathrm{O}$ and $\delta^{2} \mathrm{H}$ behaved similarly, yet there were a few distinct differences (Figure 4.14). There were two prominent depletion episodes for both isotopes that occurred around the peak snowmelt period, 26 May, and the peak precipitation period, 19 June. $\delta^{18} \mathrm{O}$ was relatively enriched prior to snowmelt $\left(20\right.$ April $\delta^{18} \mathrm{O}=-21.36 \%$ ) and was most depleted during the peak snowmelt and streamflow period $(25$ May $=-22.82 \%$. $\mathrm{A}$ second depletion period occurs on 13 June $(-22.74 \%$ ), which coincided with the largest snowfall event of the study period. $\delta^{2} \mathrm{H}$ was also the most enriched prior to snowmelt (26 April $=-165.64 \%$ ) although it became most depleted slightly earlier than the peak snowmelt and peak streamflow period (20 May $=-175.78 \%$ ). A second depletion period occurred on 13 June $(-174.98 \%$, which also coincided with the largest snowfall event of the study period. These trends were observed at Location B, Location $C$ and the outlet to varying degrees and are indicative of characteristically depleted snowmelt water reaching the stream.

\subsection{Hydrochemical Observations}

Specific conductance $(\mathrm{SpC})$ represents the ability of water to conduct electrical current and is often used to approximate the total quantity of ions, or in other words the total dissolved solids (TDS), present in water (Rodhe, 1981). SpC was measured at the basin outlet and at Location B every 15 minutes throughout the study period (Figure 4.15).

The pre-melt $\mathrm{SpC}$ value at the outlet was approximately $0.08 \mathrm{mS} / \mathrm{cm}$. The pre-melt $\mathrm{SpC}$ value for Location B could not be measured as the stream channel had yet to develop. 
The lowest value of SpC was observed at the outlet on 28 May at a value of $0.007 \mathrm{mS} / \mathrm{cm}$. The SpC at Location B reached its lowest value on 26 May at $0.002 \mathrm{mS} / \mathrm{cm}$. These low values are due to the dilution of streamwater by snowmelt water during the peak flow period. $\mathrm{SpC}$ values increased following the peak flow period to values of $0.04 \mathrm{mS} / \mathrm{cm}$ at the outlet and $0.017 \mathrm{mS} / \mathrm{cm}$ at Location B before both reaching secondary lows on 19 June of $0.013 \mathrm{mS} / \mathrm{cm}$ and $0.004 \mathrm{mS} / \mathrm{cm}$, respectively. This secondary low was associated with the most significant precipitation event of the study period.

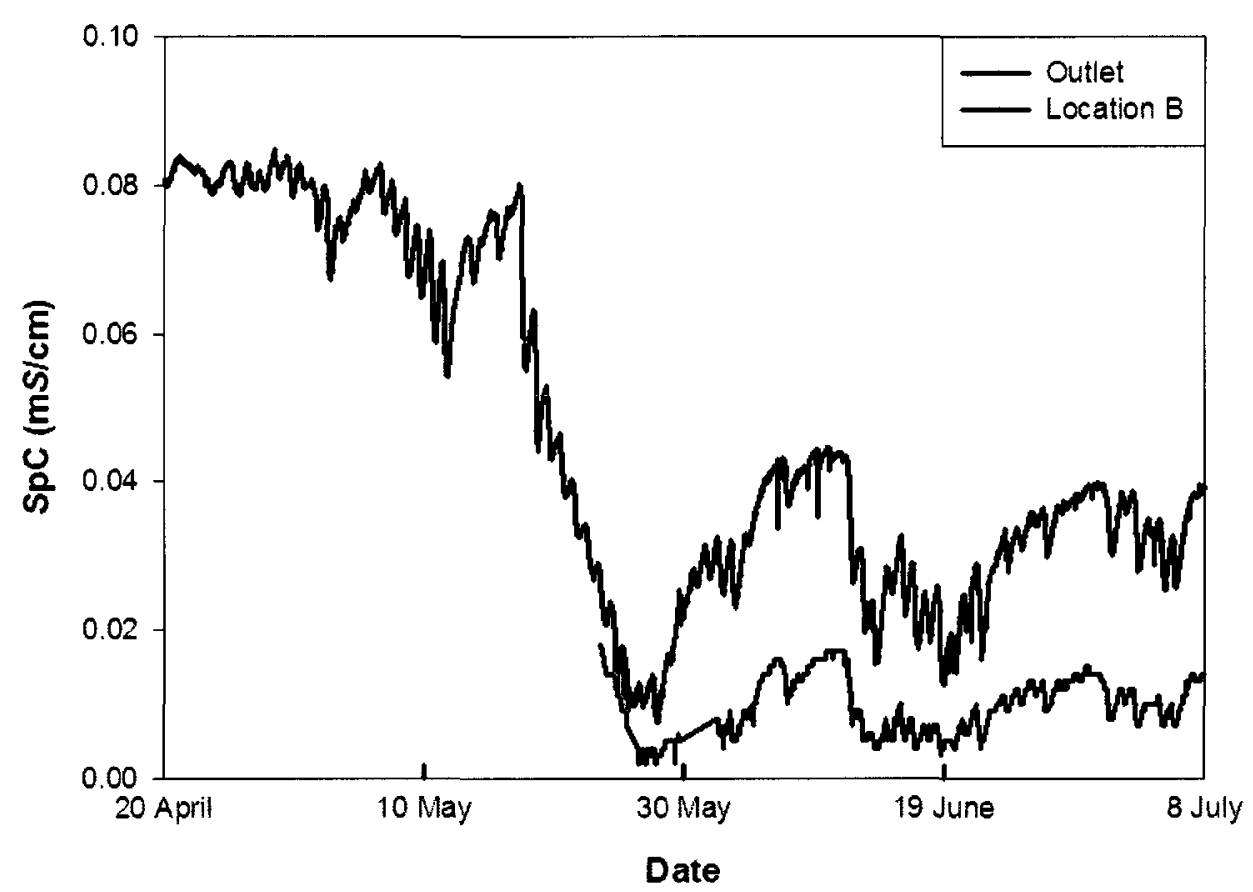

Figure 4.15. Time series of $\mathrm{SpC}$ measured at the outlet (blue) and Location B (red).

All major ions were analyzed for the outlet and Location B stream samples (Figure 4.16). The following anions and cations were above the detection limit of the chromatography instrument used: sodium $\left(\mathrm{Na}^{+}\right)$, potassium $\left(\mathrm{K}^{+}\right)$, magnesium $\left(\mathrm{Mg}^{+}\right)$, calcium $\left(\mathrm{Ca}^{+}\right)$, chloride $(\mathrm{Cl})$, nitrate $\left(\mathrm{NO}_{3}{ }^{-}\right)$and sulphate $\left(\mathrm{SO}_{4}{ }^{2}\right)$. Both bromide $\left(\mathrm{Br}^{-}\right)$and ammonium $\left(\mathrm{NH}_{4}^{+}\right)$were below the detection limit. 
At the beginning of the study period the highest concentrations, at both the outlet and Location B, were of calcium, magnesium and sodium. All three exhibited decreases in concentration during the peak flow period, mainly due to dilution from snowmelt. This

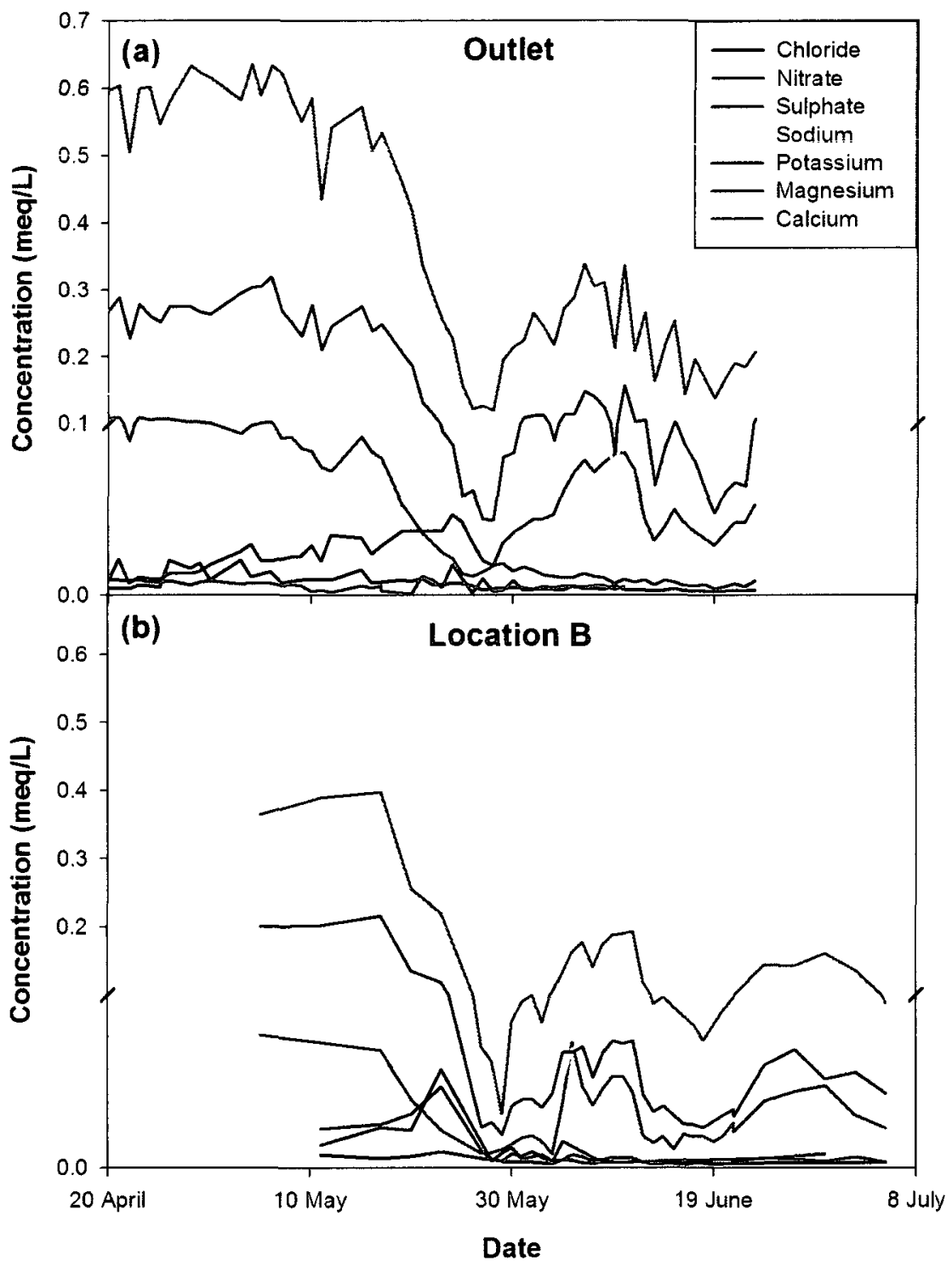

Figure 4.16. Time-series of major ions measured at (a) the outlet and (b) Location B.

dilution by snowmelt is consistent with ions that originate due to the weathering of minerals in rock (Langmuir, 1997). Conversely, nitrate and potassium concentrations were found in highest concentration during the peak flow period which is indicative of a source within organic soils (Langmuir, 1997). Chloride concentrations were highly variable, although they 
were highest at the onset of the study and gradually decreased throughout. The end-member values for baseflow, snow and ice as well as the recorded highest and lowest values for each of the solutes, at both the outlet and Location B, are presented in Table 4.9.

Sulphate, calcium, magnesium and sodium had the highest initial and overall values at both the outlet and Location B (Figure 4.16 and Table 4.9). Furthermore, it is important to note that the majority of ions measured at the outlet and Location B reached concentrations orders of magnitude greater than the values of the end-member components, indicating their non-conservative nature. Chloride is the only solute that does not exhibit this trend, as would be expected from a conservative tracer.

Table 4.9. Ion concentrations of end-member components ( \pm standard error) and high and low values for both the outlet and Location B.

\begin{tabular}{llllllll}
\hline Component & $\begin{array}{c}\mathbf{N a}^{+} \\
(\mathrm{meq} / \mathrm{L})\end{array}$ & $\begin{array}{c}\mathbf{K}^{+} \\
(\mathrm{meq} / \mathrm{L})\end{array}$ & $\begin{array}{c}\mathbf{M g}^{+} \\
(\mathrm{meq} / \mathrm{L})\end{array}$ & $\begin{array}{c}\mathbf{C a}^{+} \\
(\mathrm{meq} / \mathrm{L})\end{array}$ & $\begin{array}{c}\mathbf{C l}^{-} \\
(\mathrm{meq} / \mathrm{L})\end{array}$ & $\begin{array}{c}\mathbf{N O}^{-} \\
(\mathrm{meq} / \mathrm{L}\end{array}$ & $\begin{array}{c}\mathbf{S O}^{2-} \\
(\mathrm{meq} / \mathrm{L})\end{array}$ \\
\hline Baseflow $\pm \mathrm{S}_{\mathbf{x}}$ & 0.1033 & 0.0078 & 0.1992 & 0.4195 & 0.0048 & 0.0069 & 0.0732 \\
& \pm 0.0300 & \pm 0.0012 & \pm 0.0468 & \pm 0.0933 & \pm 0.0005 & \pm 0.0018 & \pm 0.0200 \\
Snow $\pm \mathrm{S}_{\mathbf{x}}$ & 0.0042 & 0.0023 & 0.0028 & 0.0131 & 0.0038 & 0.0026 & 0.0050 \\
& \pm .0001 & \pm 0.0004 & \pm 0.0009 & \pm 0.0009 & \pm 0.0005 & \pm 0.0007 & \pm 0.0022 \\
$\mathrm{Ice} \pm \mathrm{S}_{\mathrm{x}}$ & 0.0162 & 0.0129 & 0.0341 & 0.0789 & 0.0205 & 0.0060 & 0.0172 \\
& \pm 0.0190 & \pm 0.0035 & \pm 0.0078 & \pm 0.0113 & \pm 0.0057 & \pm 0.0006 & \pm 0.0071 \\
\hline Outlet High & $\mathbf{0 . 1 5 3 0}$ & 0.0471 & $\mathbf{0 . 3 1 9 3}$ & $\mathbf{0 . 6 3 6 4}$ & 0.0203 & 0.0179 & $\mathbf{0 . 1 0 9 5}$ \\
Outlet Low & 0.0235 & 0.0038 & 0.0436 & 0.1441 & 0.0023 & 0 & 0.0110 \\
Location B High & $\mathbf{0 . 1 2 9 6}$ & 0.0583 & $\mathbf{0 . 2 3 6 2}$ & $\mathbf{0 . 4 1 3 0}$ & 0.0096 & 0.0479 & $\mathbf{0 . 0 7 5 3}$ \\
Location B Low & 0.0200 & 0.0015 & 0.0189 & 0.0314 & 0 & 0 & 0.0081 \\
\hline
\end{tabular}

Figure 4.17 depicts the mass flux of all solutes observed at the outlet throughout the study period. In terms of mass flux, the order of solutes from greatest mass exported from the catchment during the study period to least mass was: calcium, potassium, sulphate, sodium, magnesium, nitrate and chloride.

Both calcium and magnesium are weathering products that are typically present in deeper groundwater (Pinder and Jones, 1969; Langmuir, 1997). They both showed large 
peaks in mass flux during the highest flow period, between 23 May and 29 May. This coincided well with the results obtained via hydrograph separation, which indicated that a large percentage of the peak flow was pre-event water.

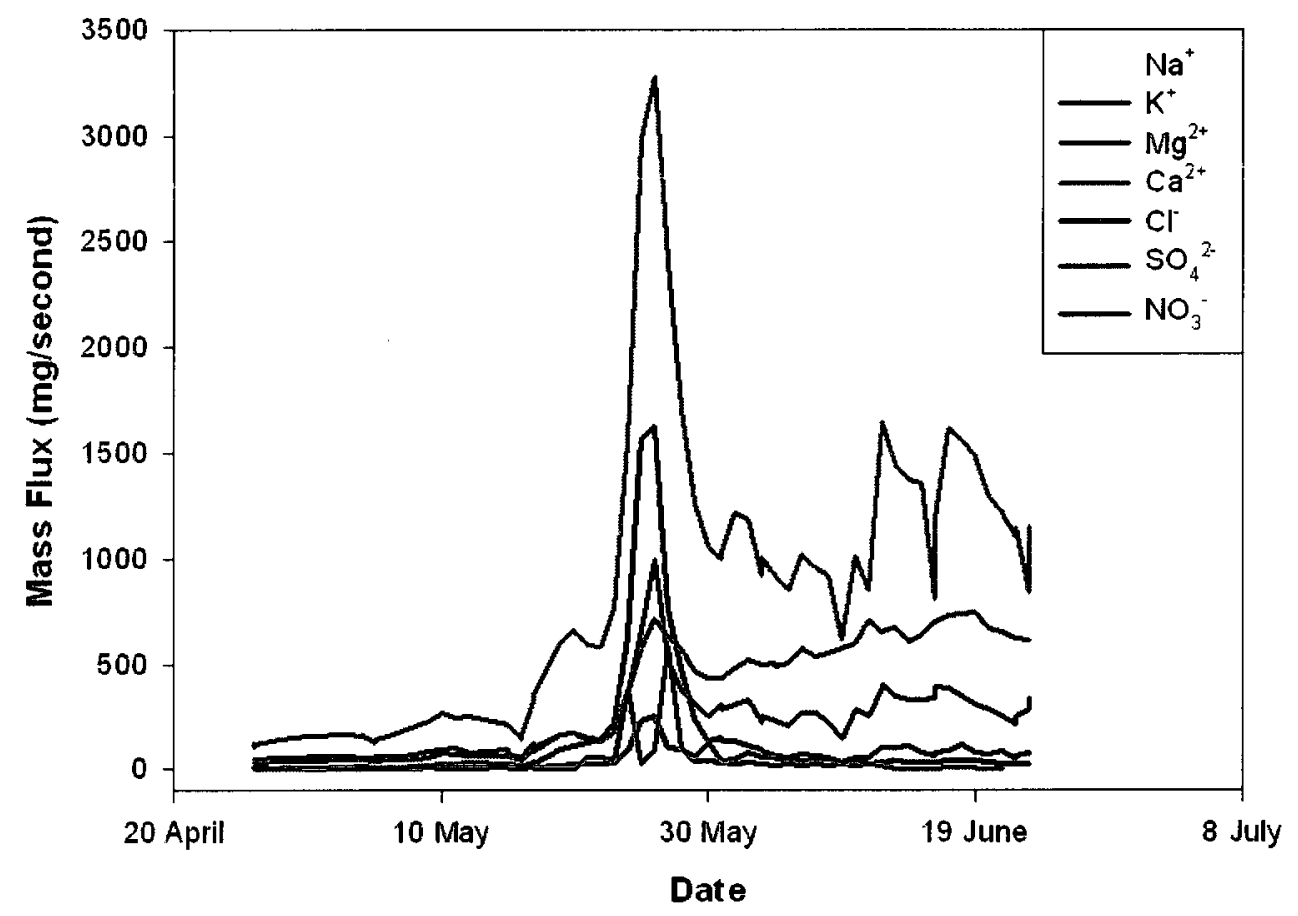

Figure 4.17. Mass flux of all solutes measured at the basin outlet throughout the study period.

Potassium originates largely in the organic soil horizon (Buttle and Sami, 1990) and showed a large peak in mass flux during the high flow period. This suggested that the preevent water was not only composed of deep groundwater, but also of soil water that was present in the basin prior to the influx of snowmelt water. Sulphate and sodium also exhibited relatively large peaks during the peak flow period. Both solutes are also often found in the organic soil horizon and can accumulate due to concentration via evapotranspiration and organic matter decomposition (Petrone et al., 2006). This was further indication of the contribution of pre-existing soil water to peak flow. Nitrate and chloride are unlikely to derive from rock weathering and have also been known to accumulate due to concentration via evaportranspiration and organic matter decomposition (Petrone et al., 
2006). They contributed to the loss of solute mass during the peak flow period, yet to a lesser extent.

A tool that is often used to evaluate the nature of tracer behavior is to determine their relationship with discharge by creating concentration versus discharge plots (i.e. Anderson et al., 1997). When these plots are strongly correlated and reproducible they can be used to predict stream flow from stream chemistry and vice versa. Evans and Davies (1998) provide a guideline regarding how to interpret concentration discharge plots (section 2.4.2), discussing each of the distinct types of concentration-discharge hysteresis loops and what they represent in terms of flow components and mixing characteristics (Table 4.10).

Table 4.10 Diagnostic features used by Evans and Davies (1998). Where $C$ is equal to solute concentration and the subscripts $M, G$ and $S$ represent the runoff components of snowmelt water, groundwater and soil water respectively.

\begin{tabular}{|c|c|c|c|c|}
\hline Type & $\begin{array}{l}\text { Rotational } \\
\text { Direction }\end{array}$ & $\begin{array}{c}\text { Relative Three } \\
\text { Component } \\
\text { Contribution }\end{array}$ & $\begin{array}{c}\text { Relative Two } \\
\text { Component } \\
\text { Contribution }\end{array}$ & Component \\
\hline C1 & Clockwise & $\mathrm{C}_{\mathrm{M}}>\mathrm{C}_{\mathrm{G}}>\mathrm{C}_{\mathrm{S}}$ & $\mathrm{N} / \mathrm{A}$ & Nitrate, potassium \\
\hline $\mathrm{C} 2$ & Clockwise & $\mathrm{C}_{\mathrm{M}}>\mathrm{C}_{\mathrm{S}}>\mathrm{C}_{\mathrm{G}}$ & C EVENT $>$ CPRE-EVENT $_{\text {PVI }}$ & $\mathrm{N} / \mathrm{A}$ \\
\hline $\mathrm{C} 3$ & Clockwise & $\mathrm{C}_{\mathrm{G}}>\mathrm{C}_{\mathrm{M}}>\mathrm{C}_{\mathrm{S}}$ & $C_{\text {PRE-EVENT }}>C_{\text {EVENT }}$ & Chloride, calcium \\
\hline$A 1$ & Anticlockwise & $\mathrm{C}_{\mathrm{S}}>\mathrm{C}_{\mathrm{G}}>\mathrm{C}_{\mathrm{M}}$ & $\mathrm{N} / \mathrm{A}$ & $\mathrm{N} / \mathrm{A}$ \\
\hline $\mathrm{A} 2$ & Anticlockwise & $\mathrm{C}_{\mathrm{S}}>\mathrm{C}_{\mathrm{M}}>\mathrm{C}_{\mathrm{G}}$ & $\mathrm{C}_{\text {EVENT }}>\mathrm{C}_{\text {PRE_EVENT }_{\mathrm{E}}}$ & $N / A$ \\
\hline $\mathrm{A} 3$ & Anticlockwise & $\mathrm{C}_{\mathrm{G}}>\mathrm{C}_{\mathrm{S}}>\mathrm{C}_{\mathrm{M}}$ & C $_{\text {PRE-EVENT }}>$ C $_{\text {EVENT }}$ & Sodium, magnesium, sulphate, $\mathrm{SpC}$ \\
\hline
\end{tabular}

Evans and Davies (1998) outline three different criteria that are needed to characterize the various hysteresis types which were outlined in detail in section 2.4.2.

Figure 4.18 depicts the concentration discharge plots for all major solutes and SpC. 

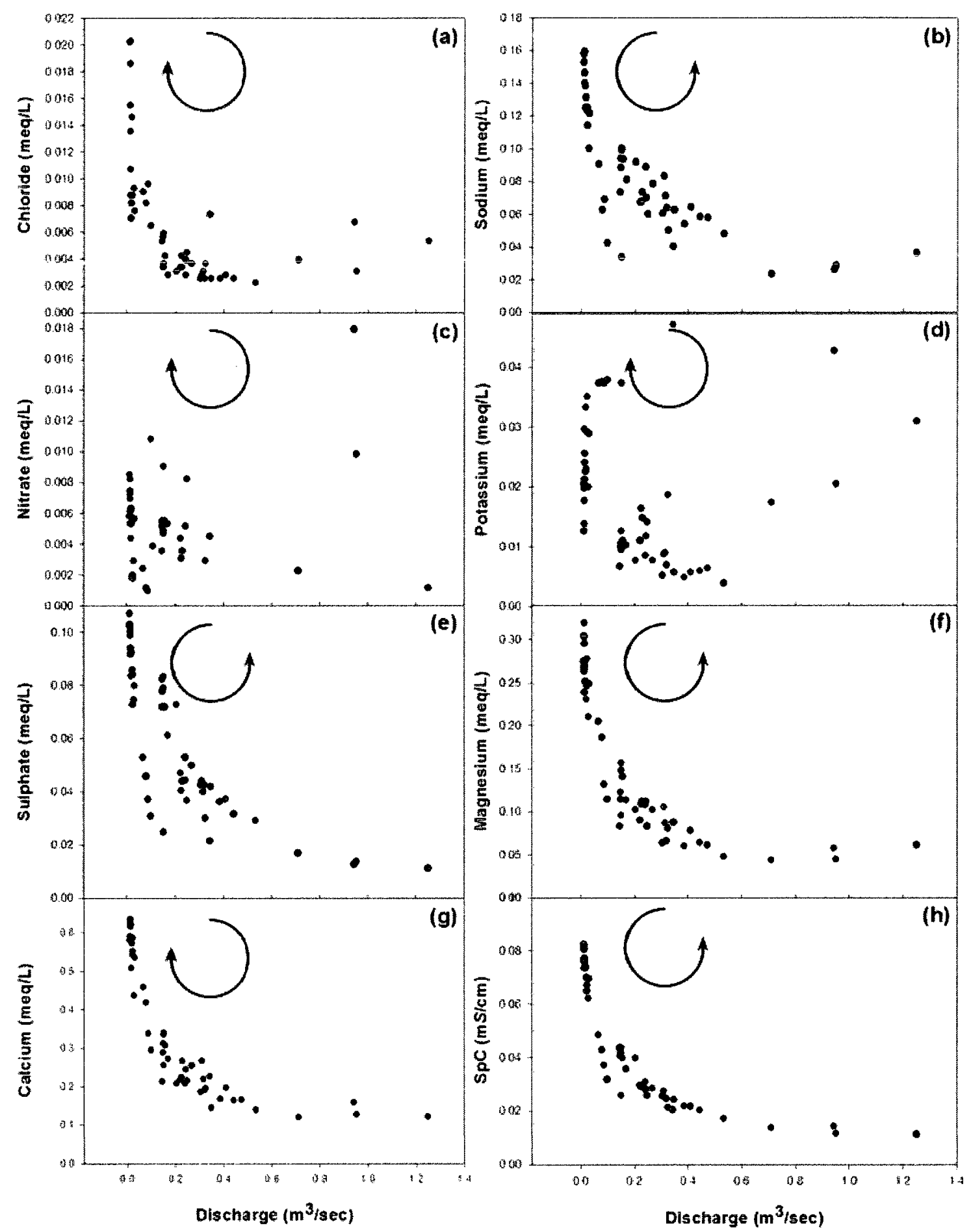

Figure 4.18. Concentration versus discharge plots for all solutes during the study period. Arrows indicate the direction of the hysteresis loops. 
The interpretations and predictions made using the hysteresis loops correlate well with the conceptual models associated with runoff generation in the study area as well as the results obtained using hydrograph separation (see Table 4.10 for the type of hysteresis loop that each component created). In this study area nitrate and potassium created type $\mathrm{C} 1$ hysteresis loops, chloride and calcium created type C3 hysteresis loops and sodium, magnesium, sulphate and $\mathrm{SpC}$ created $\mathrm{A} 3$ type hysteresis loops. This knowledge could be used in future studies in this study area to predict stream flow from stream chemistry and vice versa.

Another approach used to examine the relationship between concentration and discharge is to examine the data on logarithmic axes with the same number of log units shown on each axis (Godsey et al., 2009) as outlined in section 2.4.2. Figure 4.19 depicts the concentration-discharge relationships for all solutes and $\mathrm{SpC}$ on logarithmic axes. Based on the slopes of the data the species that experienced the most dilution is magnesium. Magnesium was followed by $\mathrm{SpC}$ (a representation of all dissolved solutes) and then calcium. The dilution of these weathering sourced ions is indicative of near-surface pathways transmitting snowmelt water to the stream. Nitrate and potassium both demonstrated relatively chemostatic behavior which may also indicate a contribution of snowmelt water and soil water traveling through the organic soil horizon to the stream. Chloride, sulphate and sodium showed slight dilution relationships with discharge. 

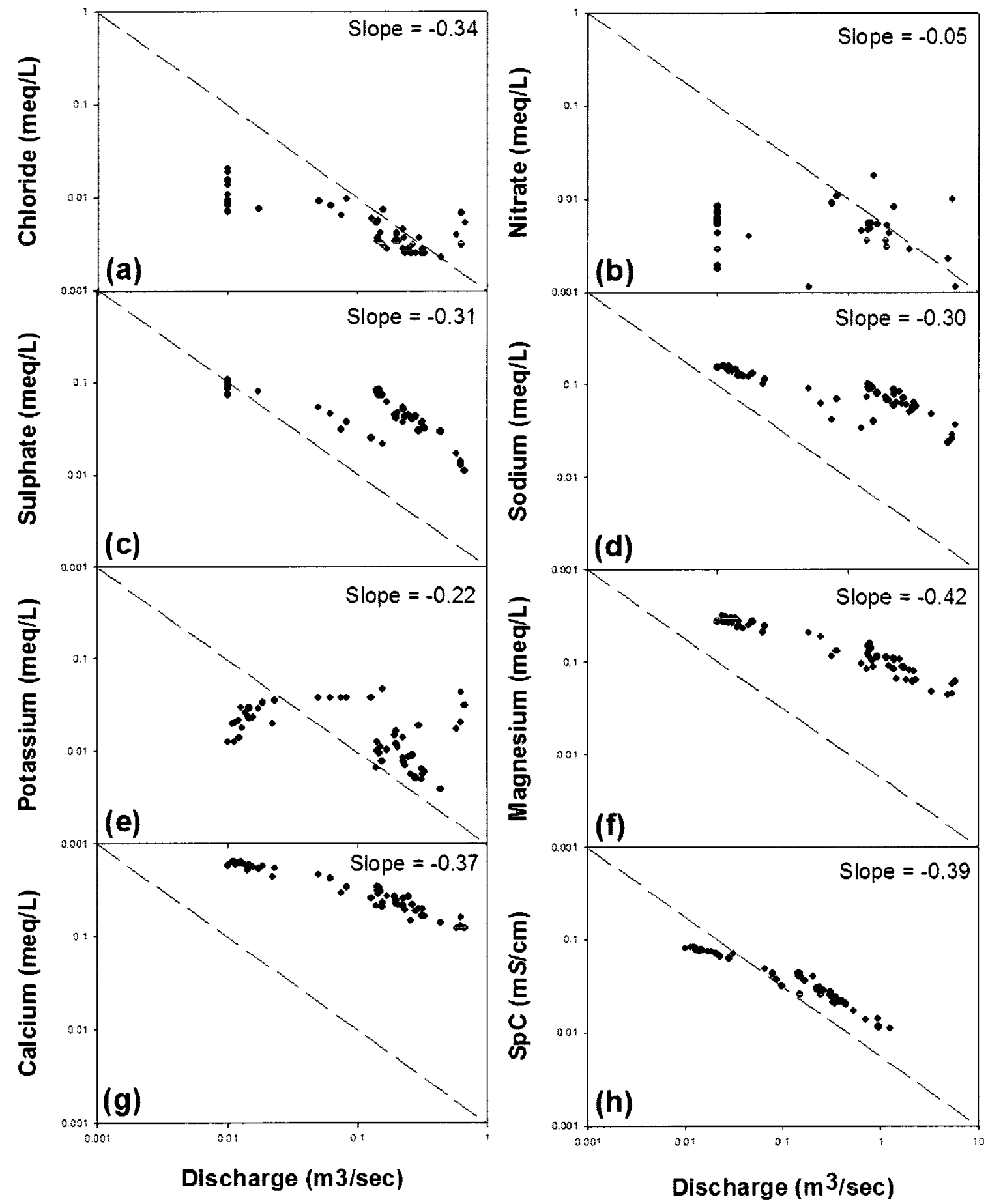

Figure 4.19. Concentration-discharge relationships for all solutes and $\mathrm{SpC}$. The dashed line indicates a $\log -\log$ slope of -1 which is indicative of perfect dilution whereas a slope of zero would indicate chemostatic behavior. 
Aqueous molar solute ratios can be used to provide additional information regarding solute behavior (Monteith et al., 2006). Figure 4.20 depicts the study period hydrograph as well as a time series of the potassium-calcium ( $\mathrm{K}: \mathrm{Ca}$ ) ratio measured at the basin outlet. The K:Ca values were also calculated for the snowmelt, ice, groundwater and soil water endmembers that contribute to streamflow and are shown on Figure 4.20 and in Table 4.11. The K:Ca ratio peaked a few days before the peak discharge values were observed. The highest value of stream $\mathrm{K}: \mathrm{Ca}$ was the same value as the soil water $\mathrm{K}: \mathrm{Ca}$ value. The fact that the discharge peak lags slightly behind that observed for $\mathrm{K}: \mathrm{Ca}$ may suggest that the earlier high flow streamwater is largely composed of soil water, which is high in potassium, that was present in the basin prior to snow fall and snowmelt. The K:Ca ratio returned to baseflow values (0.27) following the peak observed on 25 May. The peak K:Ca ratio was observed one day prior to peak discharge values.

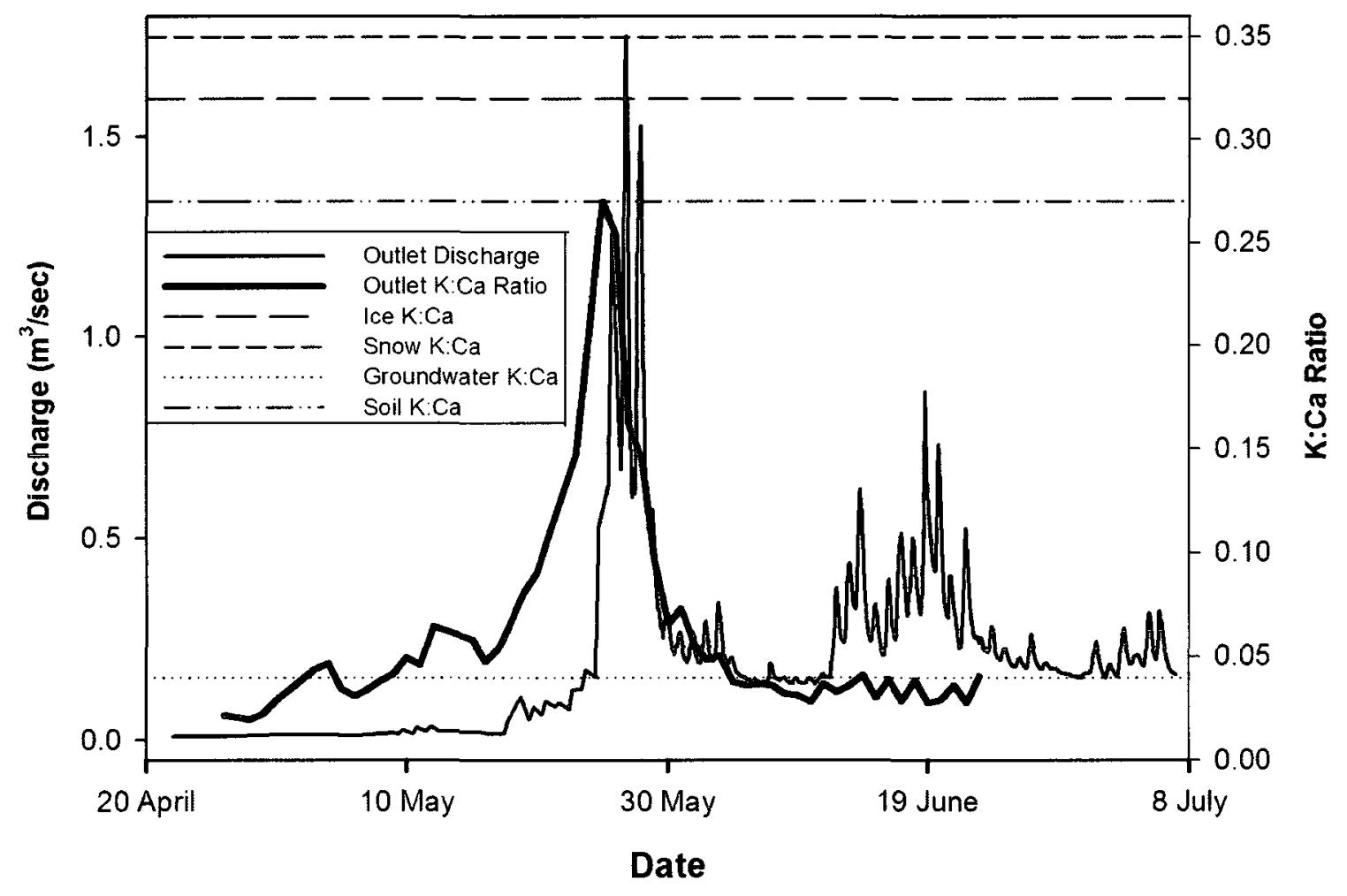

Figure 4.20. Hydrograph (black) and $\mathrm{K}: \mathrm{Ca}$ molar ratio over time (blue) measured at the basin outlet. Ice, snow, groundwater and soil $\mathrm{K}: \mathrm{Ca}$ ratios are also depicted on graph. 
Table 4.11. Potassium to calcium (K:Ca) molar ratios for ice, snow, groundwater and soil.

\begin{tabular}{lc}
\hline Component & K:Ca Ratio \\
\hline Ice & 0.32 \\
Snow & 0.35 \\
Groundwater & 0.04 \\
Soil & 0.27 \\
\hline
\end{tabular}

The combination of results obtained using the water balance calculations, hydrograph separations, end-member mixing analyses, isotope tracers and solute hydrochemistry help to reveal the various runoff processes and components that combine to create the streamflow and stream chemistry measured at the outlet of Granger basin. These runoff processes and components will be discussed in detail in Chapter 5. 


\section{DISCUSSION}

This study examined snowmelt runoff generation in a discontinuous permafrost Subarctic catchment in Yukon Territory, Canada. This study is unique in that it uses multiple approaches to explore runoff generation in Granger Basin. While other studies have used similar techniques (Carey and Woo, 1999, 2000, 2001, 2005; Carey and Quinton, 2004, 2005; McCartney et al., 2006; Quinton et al., 2009), this study is the first to combine comprehensive hydrometric, hydrochemical and isotope sampling and analyses to determine runoff components in Granger Basin.

It was originally hypothesized that aufeis and channel ice may represent an important, and often overlooked, component of the water balance for this environment. Hydrometric, isotopic and chemical analysis determined that the combined contribution of aufeis and channel ice was less than $1 \%$ of total streamflow. Despite their low contribution to streamflow both aufeis and channel ice do significantly alter streamflow pathways and the timing of discharge, as has been described by other Canadian studies of aufeis in the past (Williams and Van Everdingen, 1975; Harris et al., 1983; Clark and Lauriol, 1992, 1997;

Reedyk et al., 1995; Pollard, 2005). The hypothesis that ice ablation could augment streamflow, particularly after snowmelt, stemmed from catchment studies of icings that are much larger than the icing studied here. Nonetheless, a number of the methods intended for the exploration of the contribution of aufeis and channel ice to streamflow provided new information and insight regarding runoff generation in Granger Basin. 


\subsection{Water Balance}

Water balance studies help to characterize the pattern of hydrological processes that occur in a variety of different environments. In this study, snowmelt was the largest net gain of water, which is characteristic of nival regimes, and discharge was the largest net loss of water. The change in storage was initially a net gain of water to the basin yet it became a net loss of water in the later stages of the study period as evaporation increased and drew water from the recently recharged soil profile. The magnitude and timing of the water balance components in this study coincide well with other studies conducted within snowmelt dominated environments (Bay, 1969; Woo et al., 1983; Kane et al., 1991; Woo and Young, 1997; Carey and Woo, 1998; Metcalfe and Buttle, 1999, Carey and Woo, 2001; McCartney et al., 2006).

The magnitude of snowmelt driven runoff is controlled by the amount of SWE, timing and magnitude of precipitation events, thaw depth, antecedent soil moisture conditions and surface storage areas (Metcalfe and Buttle, 1999). The study period hydrograph was characteristic of snowmelt dominated watersheds, depicting a steep rising limb driven by snowmelt runoff and a longer recession limb with increases in discharge due to diurnal snowmelt cycles and precipitation events.

The study period runoff ratio (the fraction of total runoff to SWE + precipitation), 0.78, was high relative to other water balance studies in this research area. Carey et al. (2009) examined the water balance components of Granger Creek over four different melt seasons, including the melt season examined in this study (Table 5.1). The relatively high runoff ratio observed in this study was partly due the wet fall of 2007 (total precipitation 
Table 5.1. Water balance components from 20 April to 1 July, 2002, 2003, 2006 and 2008 (Carey et al., 2009).

\begin{tabular}{lllll}
\hline Water Balance Component & $\mathbf{2 0 0 2}$ & $\mathbf{2 0 0 3}$ & $\mathbf{2 0 0 6}$ & $\mathbf{2 0 0 8}$ \\
\hline Discharge $(\mathrm{mm})$ & 112 & 62 & 118 & 147 \\
SWE (mm) & 213 & 190 & 160 & 153 \\
Precipitation & 24 & 27 & 76 & 71 \\
Runoff Ratio & 0.47 & 0.29 & 0.50 & 0.66 \\
Previous August - October Rainfall $(\mathrm{mm})$ & 69 & 74 & 80 & 109 \\
\hline
\end{tabular}

of $109 \mathrm{~mm}$ ) which created high antecedent soil moisture conditions. In addition, a considerable amount of precipitation occurred during the study period. The 2008 snowmelt season (this study) had the lowest initial SWE yet produced the largest runoff ratio. This, in combination with the high antecedent soil moisture conditions, suggests that initial SWE and subsequent snowmelt water did not exert a large control on the rate and timing of the snowmelt hydrograph relative to the other years. Carey et al. (2009) suggested that, for Granger Basin, runoff generation during the snowmelt period is largely derived from water that existed in the soils prior to melt.

\subsection{Runoff Generation}

Other studies have examined runoff generation during the snowmelt period and have shown that pre-event water dominates peak flows (Dinçer et al., 1970; Martinec et al., 1974; Hermann and Stichler, 1980; Sklash and Farvolden, 1980; Rodhe, 1981; Bottomley et al., 1984; Hooper and Shoemaker, 1986; Obradovic and Sklash, 1986; McNamara et. al., 1997; Carey and Quinton, 2004). However, the sources and pathways of pre-event water continue to be debated due to the difficulty that arises in reconciling hydrometric and hydrochemical observations. 
Runoff generation processes have previously been studied in Granger Basin (Carey and Woo, 2001; Carey and Quinton, 2004, 2005; McCartney et al., 2006; Quinton et al., 2009) and hydrometric evidence has lead to the development of a hillslope scale conceptual model of runoff generation. The hillslope scale conceptual model developed by Carey and Woo (2001) and Carey and Quinton (2004) to describe how snowmelt is transformed into streamflow in Granger Basin is as follows:

(i) meltwater percolates from the snowpack and infiltrates frozen unsaturated organic soils.

(ii) organic soils thaw and become saturated with snowmelt. Prior to this there is little lateral transfer of water to the stream until the storage capacity of the soils is reached.

(iii) snowmelt runoff is rapidly conveyed to the stream through organic soils and preferential pathways. This runoff is confined to permafrost-underlain slopes, due to their ability to restrict percolation, and to areas directly adjacent to the stream.

(iv) as thaw continues, snowmelt water is able to percolate, interact and mix with the mineral substrate and pre-event waters to contribute to streamflow generation.

Similar conceptual models of snowmelt runoff generation have been proposed by other studies conducted in similar environments (Dingman, 1971; Santeford, 1979; Slaughter and Kane, 1979; McNamara et al., 1997; Quinton and Marsh, 1998). This study used new tracer based techniques to provide further evidence that this conceptual model is a correct representation of snowmelt runoff generation in Granger Basin.

\subsubsection{Hydrograph Separation}

Pre-event water was a major component of the snowmelt hydrograph in Granger Basin, making up $64 \%$ of the peak discharge and $\sim 73 \%$ of total stream discharge. Event water reached its peak contribution of $\sim 36 \%$ during peak flow, and represented $\sim 27 \%$ of total stream discharge throughout the study period. These values correspond well with 
literature pertaining to hydrograph separations conducted during snowmelt, which have concluded that pre-event water often accounts for over half of total streamflow (see snowmelt studies in Table 2.2). According to the hydrograph separations, peak event water (snowmelt) contribution occurred between 25 - 26 May, which coincides with peak streamflow discharge on 26 May. Furthermore, the $\delta^{18} \mathrm{O}$ and $\delta^{2} \mathrm{H}$ hydrograph separations both show that event water contributes most on the rising limb of the hydrograph indicating that event water is greatest at the beginning of the peak flow period.

The values obtained using hydrograph separation support the results of Carey and Quinton (2004) and Carey et al. (2009) who determined that pre-event water residing within the catchment prior to snowmelt dominates streamflow in Granger Basin (74-90\%), yet it still remains somewhat unclear as to how this pre-event water reaches the stream. This paradigm, where pre-event water dominates the hydrograph yet discharge appears to be driven by snowmelt (or event water), continues to be a source of debate in runoff hydrology. The combined use of hydrograph separation, end-member mixing analysis and isotopic and hydrochemical data was employed in this study in order to help elucidate the mechanisms and processes that lead to pre-event water dominating the hydrograph during the snowmelt period in Granger Basin.

\subsubsection{End-member Mixing Analysis}

End-member mixing analysis provided a visual representation of the mixing dynamics of streamflow chemistry and helped identify a source of water within the catchment that had not been sampled. The initial end-member mixing plots used ice, groundwater and snowmelt water as the three end-members that combine to form total 
streamwater. The stream values demonstrated a strong deflection towards the ice endmember which seemed unlikely due to the small volume of total basin ice meltwater that was later determined. As is often the case with end-member mixing diagrams, this triggered the search for another potential end-member (Hooper et al., 1990). Soil water is known to contribute to streamflow, particularly during the spring melt period (Bazemore et al., 1994; Carey and Woo, 2004; Laudon et al., 2004; Quinton et al., 2005) and the chemical signature, (both isotopic and ionic) of the aufeis and channel ice was very similar that of the soil water signature. Using data archived from the 2006 field season (Duarte, 2007), additional chloride, $\delta^{18} \mathrm{O}$ and $\delta^{2} \mathrm{H}$ end-member mixing diagrams were created using the soil water end-member. The soil water end-member, which was assumed to be similar between the two years, contained the stream values better than the ice end-member and was a more likely runoff component. Quinton et al. (2005) determined that up to $50 \mathrm{~mm}$ of water (which infiltrated into the active layer near the end of the previous summer or fall) could be stored within organic soils in Granger Basin. Soil water could represent up to $29 \%$ of total runoff therefore making it a more plausible end-member than ice meltwater.

The end-member mixing diagrams allowed for the determination of three endmembers that combine to form total streamwater, groundwater, soil water and snowmelt water. Each of these end-members has a unique chemical and isotopic signature and contributes to streamflow in varying degrees of magnitude and timing. The streamflow evolution arrows in Figure 4.12 helped elucidate the timing of each of their contributions. For both the chloride versus $\delta^{18} \mathrm{O}$ and chloride versus $\delta^{2} \mathrm{H}$ end-member mixing diagrams, pre-melt streamflow chemistry began at the groundwater end-member. The stream water then deflected towards the soil water end-member and then moved towards the snowmelt 
water end-member. Towards the end of the study period, the stream water values returned towards the groundwater end-member value yet they were no longer bounded by the three proposed end-members. Although this may have been due to uncertainty in the end-member calculations, it may also indicate that another source of stream water has been overlooked. Baseflow at upstream sampling locations (Locations B and C) was not observed until 8 May. Therefore the baseflow samples used to estimate the groundwater chemistry (sampled from 20 - 22 April) did not include this upstream baseflow water which may be responsible for discrepancies in the groundwater end-member signature.

Rain water was not sampled in this study, however the average annual local meteoric precipitation value for Whitehorse is known and rain water has been sampled in the study area in previous years. When the estimated average rain water end-member is plotted on the mixing diagrams it lies between the groundwater and snowmelt water values and could represent an important source of stream water in this study. The timing of this deflection coincides with the largest precipitation event, both rain and snow, which occurred near the end of the study period (19 June) and is most likely due to stored snowmelt water and rain water reaching the stream.

\subsubsection{Isotopic Observations}

The most depleted values of both $\delta^{18} \mathrm{O}$ and $\delta^{2} \mathrm{H}$ were observed during the peak flow period (26 May). $\delta^{18} \mathrm{O}$ and $\delta^{2} \mathrm{H}$ both demonstrated a second period of depletion during the largest precipitation event of the study period (19 June). The first depletion occured in response to characteristically depleted snow meltwater reaching the stream. This effect has previously been described in studies conducted in snowmelt dominated environments 
(Rodhe, 1981; Cooper et al., 1993; Shanley et al., 1995; Taylor et al., 2001; Feng et al., 2002;

Carey and Quinton, 2004). The double paradox presented by Kirchner (2003) discusses this issue and poses the question: "if the stream is composed primarily of pre-event water why do we observe stream chemistry that suggests that streamwater is composed largely of event water?" It is important to observe that the event water does reach its peak contribution during the peak flow period which may explain the relatively large observed isotopic depletions.

The second depletion occurred in conjunction with the largest precipitation event, both rain and snow, of the study period. The depletion suggests that snow meltwater, from both the snowfall event and meltwater that was stored throughout the basin during the main melt period, was pushed through the soils during the precipitation event thus contributing to the observed depletion in streamwater values.

The observed variation in stream water isotope values is consistent with relatively simple three-component mixing, where well mixed pre-event waters, both groundwater and soil water, sustain baseflow and seasonally variable snowmelt and rain water inputs account for the depletion episodes observed (Rodgers et al., 2004). The peak snowmelt contribution estimated using isotope signatures occurred on 24 -25 May, which is consistent with the results of the hydrograph separation and peak streamflow discharge.

\subsubsection{Hydrochemical Observations}

The largest decline in $\mathrm{SpC}$ occurred during the peak flow period which is similar to the trend observed with $\delta^{18} \mathrm{O}$ and $\delta^{2} \mathrm{H}$ and was in response to characteristically low SpC 
snow meltwater reaching the stream. A second low $\mathrm{SpC}$ period was observed during the large precipitation event (19 June). Both of these declines indicated that low $\mathrm{SpC}$ waters were transmitted to the stream relatively quickly which provided evidence that a certain amount of snow meltwater is able to travel through near-surface pathways without interacting with the deeper mineral substrate (Gibson et al., 1993; Laudon et al., 2002; Taylor et al., 2002, Carey and Quinton, 2004). The SpC of pre-event soil water has been determined to be similar to that of snow meltwater, therefore the $\mathrm{SpC}$ depletion observed may have been a result of preevent soil water reaching the stream (Carey and Quinton, 2004).

Streamwater sampled near the headwater, Location B, contained a lower concentration of ions which is due to the shorter flow paths and residence times of water at higher elevations due to steeper slopes and greater permafrost extent. At both the outlet and Location B, ions typically found in deeper groundwater (calcium, magnesium, sulphate and sodium) had maximum concentrations prior to snowmelt and declined in concentration during the snowmelt period, suggesting a shift occurred in the source or flow path between early and late spring. Potassium (typically located in organic soils) significantly increased in concentration early in the snowmelt period and then quickly declined, suggesting a finite pool of potassium from the organic soils. These results coincide well with the concept that streamflow is dominated by deeper groundwater prior to melt and that soil water and snow melt water begin to contribute to streamflow during the initial snowmelt and high flow period.

The flux of ions leaving the catchment $\left(\mathrm{mg} \mathrm{s}^{-1}\right)$ is another method of interpreting hydrochemical data. Calcium and magnesium, both weathering products associated with 
deeper groundwater (Elsenbeer et al., 1995), demonstrated large peaks in mass flux during the highest flow period, which corresponded with the results of the hydrograph separation (which indicated that a large percentage of streamflow is pre-event water). Potassium originates within the organic soil horizon and also showed a large peak in mass flux during the high flow period. This suggests that pre-event water is not solely composed of deep groundwater but also of soil water that existed in the basin prior to the onset of melt. The large potassium mass flux could also indicate snowmelt water that has traveled through the organic soil horizon and into the steam. Sulphate and sodium are present in organic soils and both showed relatively large mass fluxes during the high flow period which is further indication of the contribution made by pre-melt soil water.

Concentration versus discharge plots allow examination of the patterns and relationships that exist between solutes and streamflow. Using the guidelines of Evans and Davies (1998) the concentration-discharge plots predicted that nitrate and potassium concentrations would be greatest in snowmelt water, followed by groundwater and then soil water. This is not what would be expected considering both solutes are thought to originate in organic soils. This misinterpretation may be due to difficulties determining the trend of their concentration-discharge relationships. Chloride and calcium concentrations were predicted to be greatest in groundwater, followed by snowmelt water and then soil water. Sodium, magnesium, sulphate and $\mathrm{SpC}$ were predicted to be greatest in groundwater, followed by soil water and then snowmelt water. For chloride, calcium, sodium, magnesium, sulphate and $\mathrm{SpC}$ the two-component mixing guidelines predicted that their concentrations were greater in pre-event water than event water. For the most part, the predictions that were drawn from this simple graphical procedure coincide well with the conceptual models 
of runoff generation in this research area as well as the results obtained via hydrograph separation and EMMA. When concentration-discharge plots are well defined, it becomes possible to use them to predict stream chemistry from discharge measurements and vice versa. As a result, these graphs may be useful in future studies within Granger Basin when time consuming and costly high resolution sampling and analysis is not possible.

Plotting concentration versus discharge on $\log -\log$ axes provided an assessment of solute behavior as discharge varied. Based on the log-log plots of concentration and discharge, the species that experiences the most dilution is magnesium. Magnesium was followed by SpC (a representation of all dissolved solutes) and then calcium. Streamflow dominated by pre-event water becomes diluted by snowmelt water thus diluting the major weathering ions such as magnesium and calcium. Nitrate and potassium both demonstrate relatively chemostatic behavior which may be due to the fact that they both originate in organic soils. Therefore as discharge increases, and soil water and meltwater traveling through the organic soils also increases, the relative contributions of nitrate and potassium also increase. Chloride, sulphate and sodium show slight dilution relationships with discharge as they are also more prominent in pre-event waters which become diluted by event water.

The aqueous molar ratios of $\mathrm{K}: \mathrm{Ca}$ helped to assess water flow paths to the stream channel. Large ratios denoted fast or surface pathways and small ratios represented slower subsurface pathways. This assumed that a vertical zonation of potassium and calcium from the organic layer to the bedrock exists in the study area, with decreasing potassium with depth due to uptake and immobilization and increasing calcium with depth due to greater weathering. Elsenbeer $e t$ al. (1995) used this technique to determine relative contributions of 
groundwater and soil water to streamflow. The largest $\mathrm{K}$ :Ca ratio was observed just prior to peak flows which implies that pre-event soil water contributions were greatest at that time. The K:Ca ratio returns quickly to baseflow values following this peak, suggesting that the finite pool of potassium (and therefore pre-event soil water) from the organic soil horizon was flushed out during the early stages of snowmelt runoff generation.

\subsubsection{Summary}

Snowmelt runoff in this study exhibited three main trends, which are similar to those observed at the hillslope scale by Carey and Woo (2001):

(i) an increase in runoff during the main melt period occurred which corresponded with the saturation of the organic layer followed by a rapid decline in runoff after the disappearance of the snow.

(ii) diurnal fluctuations were observed in the hydrograph which were related to the daily rhythm of snowmelt.

(iii) an increase of runoff occurred in response to rain and snow events during the later stages of the study period.

Peak flow was dominated by pre-event water contributions (both groundwater and soil water), which, according to McCarney et al. (2006), were transmitted rapidly along preferential pathways within the organic layer and along the interface between the organic and mineral soil layers. The substantial pre-event water contribution to the snowmelt hydrograph is therefore a result of infiltrating meltwater displacing pre-event soil water already in the melting active layer towards the stream. Based on the results of the water balance and the isotopic, chemical and field observations, the previous conceptual model of the transformation of snowmelt to streamflow in Granger basin is accurate. However, results from this study indicate that once organic soils thaw and become saturated with snowmelt water, the displacement of pre-event soil water from the melting active layer occurs. These 
findings relate well to the work of Carey and Quinton (2004) who determined that pre-event soil water represented an important contribution to snowmelt runoff in this study area. This study was able to combine the use of hydrometric, isotopic and hydrochemical observations to elucidate the timing of pre-event soil water contribution.

The percent of pre-event water that contributed to streamflow during the study period was determined to be $\sim 126 \mathrm{~mm}$ and soil water was estimated to represent up to 50 $\mathrm{mm}$ of the total pre-event water contribution. The soil water contribution could therefore represent up to $40 \%$ of the pre-event contribution and up to $29 \%$ of total streamflow. If groundwater is estimated to contribute the remaining $60 \%$ of pre-event water, that would be equivalent to approximately $76 \mathrm{~mm}$ ( $44 \%$ of total streamflow). Event water was estimated to contribute $47 \mathrm{~mm}$ of water to streamflow ( $27 \%$ of total streamflow). If soil water, groundwater and snowmelt contributions are added together the result is total streamflow $(29 \%+44 \%+27 \%=100 \%)$.

The contribution of event water (snowmelt water) was calculated to be $\sim 47 \mathrm{~mm}$. Given that $153 \mathrm{~mm}$ of basin wide snow was available for melt, it is important to consider where the remaining $106 \mathrm{~mm}$ of snowmelt water ended up. The concept that the soil water that existed in the basin prior to melt was pushed out by snowmelt water would result in an equal amount of snow meltwater becoming stored in the basins soils. If soil water contributed a maximum of $50 \mathrm{~mm}$ of water and was replaced by infiltrating snowmelt water, then that leaves approximately $56 \mathrm{~mm}$ of snow meltwater unaccounted for. A total of 68 $\mathrm{mm}$ of precipitation fell during the study period and an estimated $88 \mathrm{~mm}$ of evaporation occurred. If the remaining $56 \mathrm{~mm}$ of snow meltwater is assumed to reside in the near-surface 
soils along with the precipitation that would result in $124 \mathrm{~mm}$ of water being available for evaporation. Subtracting the potential water lost to evaporation leaves $36 \mathrm{~mm}$ of water unaccounted for. This value is within the range of error for this type of water balance estimate.

\subsection{Sources of Error}

The effect of aufeis, channel ice and channel snow on streamflow pathways and the timing of discharge can cause delays in observations of streamflow generation further downstream. In Granger Basin, flow is inhibited by dense snow and aufeis in the channel (McCartney et al., 2006). Due to this effect, runoff generation may appear to be delayed when snowmelt occurs and is transmitted to the stream yet is retained or diverted before it reaches the basin outlet (Woo and Sauriol, 1980; Russell et al., 2005).

Accurate quantification of pre-melt SWE remains one of the most important aspects of any hydrometric study involving snowmelt. Much error is associated with the extrapolation of point source data to larger areas (Woo, 1997). In this study, 8 snow transects were placed throughout the basin and were used to estimate basin wide SWE. Although these transects were representative of a variety of different environments within the basin, uncertainty remains regarding the ability to scale up to the entire basin.

All of the error associated with the SWE, evaporation, precipitation and discharge measurements and calculations were accumulated in the change in storage term of the water balance equation, which is calculated as a residual. It should be noted that these values 
provide an estimate of the water fluxes occurring within Granger Basin during the snowmelt period.

The uncertainty associated with the hydrograph separations are related to systematic and analytical errors related to tracer chemistry (Table 4.5). The estimated uncertainties for the hydrograph separation components are acceptable $(0.2-33.1 \%)$ and are also similar in magnitude to those obtained in other studies conducted during the spring melt season (Metcalfe and Buttle, 2001; Laudon et al., 2004; Carey and Quinton, 2004).

While the determination of the total streamflow discharge $\left(Q_{T}\right)$ and total stream chemistry $\left(\mathrm{C}_{\mathrm{T}}\right)$ were straightforward, the selection of pre-event and event water end-member signatures were more problematic. The spatial and temporal variability of the meltwater isotopic signature is large, and the methods used to characterizing the event water signature may not have adequately characterized the snowmelt isotopic signature. However, the fractionation that occurs during snowmelt initially causes a depleted signature and later during melt causes an enriched signature. By taking an overall average of meltwater and snow core values it is possible to characterize the total isotope signature well (Taylor et al., 2002). Pre-melt baseflow samples were used to determine the pre-event end-member signature, however not all areas of the stream were contributing to baseflow at that time. This is especially true for higher elevation upstream locations, therefore creating the possibility of error within the estimate of the groundwater end-member signature. Uncertainties also result from systematic errors in the isotope and chemical signatures. Random errors associated with spatial and temporal variability also exist yet they are difficult to quantify. 


\section{CONCLUSIONS}

This research examined the role runoff components on streamflow hydrology and hydrochemistry within Granger Basin $\left(7.6 \mathrm{~km}^{2}\right)$, a discontinuous permafrost headwater watershed located within the larger Wolf Creek Research Basin $\left(195 \mathrm{~km}^{2}\right)$, Yukon Territory, Canada. This study is unique in that it uses multiple methods to explore runoff generation. While other studies have used similar techniques, this study is the first to combine comprehensive hydrometric, hydrochemical and isotope sampling and analyses to evaluate snowmelt runoff components in Granger Basin. The specific research questions of this research were answered as follows:

i) The main components of the water balance in Granger Basin are snowmelt (152 $\mathrm{mm})$, precipitation $(68 \mathrm{~mm})$, evaporation $(88 \mathrm{~mm})$, discharge $(173 \mathrm{~mm})$ and change in storage $(-41 \mathrm{~mm})$.

ii) Aufeis and channel ice represent less than $1 \%$ of total streamflow, however, they do alter streamflow pathways and the timing of discharge.

iii) Pre-event water represents $\sim 73 \%$ of total streamflow during the snowmelt period. Event water contributed most during the peak flow period $(\sim 36 \%)$ and contributed $\sim 27 \%$ of total streamflow during the study period.

Isotope and ion chemistry helped to elucidate the flow paths and the timing of runoff generating components. Based on the results of the water balance and the isotopic, chemical and field observations, runoff generation in Granger Basin occurs as meltwater percolates from the snowpack and infiltrates frozen unsaturated organic soils. Organic soils then thaw and become saturated with snowmelt. Prior to this there is little lateral transfer of water to the stream until the storage capacity of the soils is reached. Pre-event soil water is then displaced from the melting active layer by infiltrating snowmelt following which snowmelt runoff is rapidly conveyed to the stream through organic soils via preferential pathways. Snowmelt runoff is confined to permafrost-underlain slopes, due to their ability to 
restrict percolation, and to areas directly adjacent to the stream. As thaw continues, snowmelt water is able to percolate, interact and mix with the mineral substrate and preevent waters to contribute to streamflow generation.

In summary, the combined use of hydrometric, isotopic and hydrochemical data facilitates the investigation of basin wide runoff components and flow pathways. Although aufeis and channel ice did not represent a large contributing source area they were observed to alter streamflow pathways and the timing of discharge. This research led to new discoveries including a greater appreciation for the information and understanding that can be gained using multiple complimentary methods. This work helped to validate and build upon the conceptual model of the processes and mechanisms that lead to streamflow generation in Granger Basin. It is important that tracer based studies, such as this one, continue to evolve in order to refine our understanding of runoff generation and also to help validate and conceptualize more accurate hydrochemical models.

These results contribute to an improved understanding and conceptualization of catchment hydrology in Granger Basin. The exploration of streamflow generation and hydrochemistry continues to depend upon the careful integration of results from hydrometric, isotopic and hydrochemical methods. The ability to employ these and similar methods at different spatial and temporal scales needs to be explored further in future investigations in this study area. 


\section{APPENDIX A}

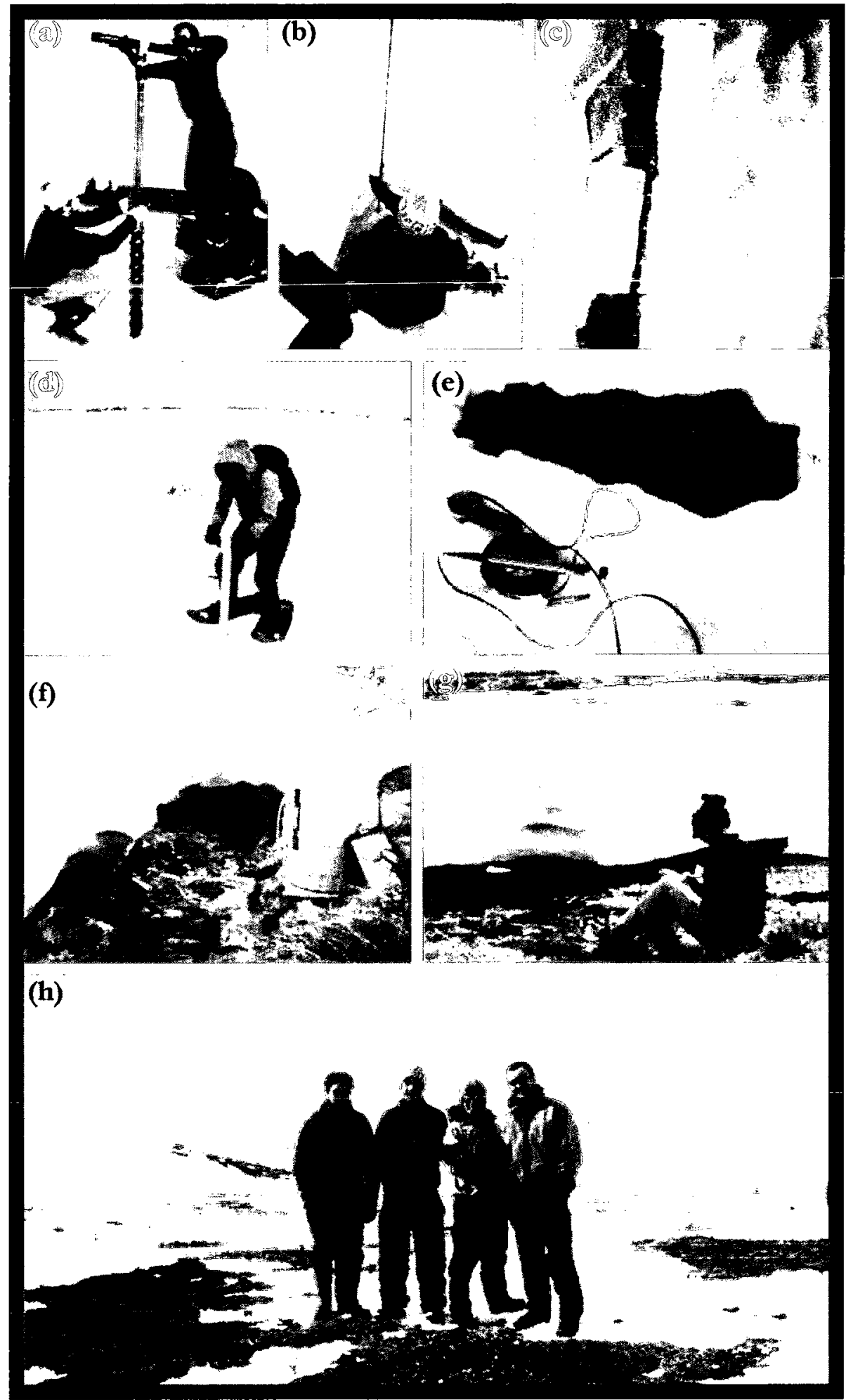

(a) Ice core using hand auger, (b) snow pit with lysimeter, (c) ice core, (d) snow density measurement, (e) Quanta water quality instrument, (f) ISCO automatic water sampler, (g) salt dilution measurement, and (h) field group near headwater. 


\section{REFERENCES}

Addison, P. A. 1977. Studies on evapotranspiration and energy budgets on Truelove Lowland. Truelove Lowland, Devon Island, Canada: A High Arctic Ecosystem, L. C. Bliss (Editor), University of Alberta Press, 281-300.

Åkerman, H. J. 1982. Studies on naledi (icing) in West Spitsbergen. Fourth Canadian Permafrost Conference, 2-6 March, 1981, Calgary, Alberta. National Research Council of Canada, Ottawa, 189-202.

Alekseyev, V. R. 1969. Siberian naleds. U.S.S.R. Academy of Sciences. Translation U.S. Army Cold Regions Research and Engineering Laboratory Draft Translation 399, Hanover, New Hampshire, 300.

Alekseyev, V. R. \& Tolstikhin, O. N. 1973. Questions of terminology in study of naleds. U.S. Army Cold Regions Research and Engineering Laboratory, Hanover, New Hampshire, 187-191.

Anderson, S. P., Dietrich, W. E., Torres, R., Montgomery, D. R. \& Loague, K. 1997. Concentration-discharge relationships in runoff from a steep, unchanneled catchment. Water Resources Research, 33, 211-225.

Anisimova, N. P. 1973. Ground water in the cryolithosphere. U.S.S.R. Academy of Sciences, Second International Conference on Permafrost, Lectures and Reports. Translation U.S. Army Cold Regions Research and Engineering Laboratory Draft Translation 437, Hanover, New Hampshire, 172.

Barnes, B. S. 1940. Discussion on analysis of run-off characteristics by O. H. Meyer. Trans. Am. Soc. Civil Engrs., 105, 104-106.

Bay, R. R. 1969. Runoff from small peatland watersheds. Journal of Hydrolgoy, 9, 90-102.

Bazemore, D. E., Eshleman, K. N. \& Hollenbeck, K. J. 1994. The role of soil water in stormflow generation in a forested headwater catchment: synthesis of natural tracer and hydrometric evidence. Journal of Hydrology, 162, 47-75.

Betson, R. P. 1964. What is a watershed runoff? Journal of Geophysical Research, 69, 1541-1551.

Birks, S. J., Edwards, T. W. D., Gibson, J. J., Michel, F. A., Drimmie, R. J. \& MacTavish, D. 2003. Canadian Network for Isotopes in Precipitation. University of Waterloo, Meteorological Service of Canada.

Bishop, K. H., Grip, H., \& O’Neill, A. 1990. The origins of acid runoff in a hillslope during storm events. Journal of Hydrology, 116, 25-61.

Boelter, D. H. 1972. Watertable drawdown around an open ditch in organic soils. Journal of Hydrology, 15, 329-340. 
Bolton, W. R., Hinzman, L. D. \& Yoshikawa, K. 2000. Stream flow studies in a watershed underlain by discontinuous permafrost. Water Resources in Extreme Environments, Kane D. L. (Ed.), American Water Resources Association Proceedings: Anchorage, 31-36.

Bonell, M., Pearce, A. J. \& Stewart, M. K. 1990. The identification of runoff-production mechanisms using environmental isotopes in a tussock grassland catchment, eastern Otago, New Zealand. Hydrological Processes, 4, 15-34.

Bonell, M. 1993. Progress in the understanding of runoff generation in forests. Journal of Hydrology, 150, 217-275.

Bottomley, D. J., Craig, D. \& Johnston, L. M. 1984. Neutralization of acid runoff by groundwater discharge to streams in Canadian Precambrian shield watersheds. Journal of Hydrology, 75, 1-26.

Bottomley, D. J., Craig, D. \& Johnston, L. M. 1986. Oxygen-18 studies of snowmelt runoff in a small Precambrian shield watershed: implications for streamwater acidification in acid-sensitive terrain. Journal of Hydrology, 88, 213-234.

Brown, R. J. E. 1970. Permafrost in Canada - its influence on northern development. University of Toronto Press, Toronto, Ontario: 234.

Brown, R. J. E. 1974. Distribution and environmental relationships of permafrost. In Proceedings of $W$ orkshop Seminar, Canadian National Committee, International Hydrological Decade, Environment Canada, Ottawa: 1-6.

Brown, R. J. E. 1977. Permafrost in Canada. Hydrological Atlas of Canada. Environment Canada, Ottawa.

Brown, V. A., McDonnell, J. J., Burns, D. A. \& Kendall, C. 1999. The role of event water, a rapid shallow flow component, and catchment size in summer stormflow. Journal of Iydrology, 217: 171-190.

Burns, D. A., McDonnel, J. J., Hooper, R. P., Peters, N. E., Freer, J. E., Kendall, C. \& Beven, K. 2001. Quantifying contributions to storm runoff through end-member mixing analysis and hydrologic measurements at the Panola Mountain Research Watershed (Georgia, USA). Hydrological Processes, 15, 1903-1924.

Buttle, J. M. 1994. Isotope hydrograph separations and rapid delivery of pre-event water from drainage basins. Progress in Physical Geography, 18: 16-41.

Buttle, J. M., Vonk, A. M. \& Taylor, C. H. 1995. Applicability of isotopic hydrograph separation in a suburban basin during snowmelt. Hydrological Processes, 9, 197-211.

Buttle, J. M. \& Sami, K. 1990. Recharge processes during snowmelt: an isotopic and hydrometric investigation. Hydrological Processes, 4: 343-360. 
Carey, K. 1970. Icing occurrence, control and prevention: an annotated bibliography. USA/CRREL, Special Report 151, Hanover, New Hampshire.

Carey, K. 1973. Icings developed from surface water and groundwater. USA/CRREL, Cold Regions Science and Engineering Monograph 111-D3, Hanover, New Hampshire.

Carey, S. K. \& Woo, M. K. 1998. Snowmelt hydrology of two subarctic slopes, southern Yukon, Canada. Nordic Hydrology, 29: 331-346.

Carey, S. K. \& Woo, M. K. 1999. Hydrology of two slopes in subarctic Yukon, Canada. Hydrological Processes, 13: 2549-2562.

Carey, S. K. \& Woo, M. K. 2000. The role of soil pipes as a slope runoff mechanism, subarctic Yukon, Canada. Journal of Hydrology, 233: 206-222.

Carey, S. K. \& Woo, M. K. 2001. Spatial variability of hillslope water balance, Wolf Creek basin, subarctic Yukon. Hydrological Processes, 15: 3113-3132.

Carey, S. K. and Woo, M. K. 2005. Freezing of subarctic hillslopes, Wolf Creek Research Basin, Yukon, Canada. Artic, Antartic, and Alpine Research, 37, 1-10.

Carey, S. K. \& Quinton, W. L. 2004. Evaluating snowmelt runoff generation in a discontinuous permafrost catchment using stable isotope, hydrochemical and hydrometric data. Nordic Hydrology, 35: 309-324.

Carey, S. K. \& Quinton, W. L. 2005. Evaluating runoff generation during summer using hydrometric, stable isotope, and hydrochemical methods in a discontinuous permafrost alpine catchment, Hydrological Processes, 19: 95-114.

Carey, S. K., Boucher, J. L. \& Duarte, C. M. 2009. A multi-year perspective on snowmelt runoff generation in an alpine subarctic catchment. In press. $17^{\text {th }}$ International Northern Research Basin Symposium and Workshop, Canada, 2009.

Chacho, E. F. \& Bredhauer, S. 1983. Runoff from a small sub-arctic watershed, Alaska. In Proceedings of Fourth International Conference on Permafrost. 115-120.

Chekotillo, A.. Tsvid, A. \& Makarov, V. 1960. Icings in the USSR and their control. Translated in 1970 by US Dept. Commerce, Nat. Tech. Info. Service no. AD711933.

Christophersen, N., Kjaernsrod, S. \& Rodhe, A. 1984. Preliminary evaluation of flow patterns in the Birknes catcment using natural ${ }^{18} \mathrm{O}$ as a tracer. Hydrological and Hydrogeochemical Mechanisms and Model Approaches to the Acidification of Ecological Systems. Nordic Hydrologic Programme, Oslo, Norway, 29-40.

Christophersen, N., Neal, C., Hooper, R. P., Vogt, R. D. \& Andersen, S. 1990. Modeling strreamwater chemistry as a mixture of soilwater end-members $-A$ step towards $2^{\text {nd }}$ generation acidification models. Jounal of Hydrology, 116, 307-320. 
Christophersen, N. \& Hooper, R. P. 1992. Multivariate-analysis of stream water chemical data - the use of principal component analysis for the end-member mixing problem. Water Resources Research, 28, 99-107.

Christotinova, L. T. \& Tolstikhin, O. N. 1973. Certain questions in formation of chemical composition of naled ice (an example of naled in Ulakhan-Taryn and central Yukatia). Siberian Naleds, Cold Regions Research and Engineering Laboratory, Draft Translation 399, 172-183.

Church, M. 1974. Icing in frozen terrain: a summary review. Unpublished report to Mackenzie Valley Pipeline Enquiry.

Clark, I. \& Lauriol, B. 1992. Kinetic enrichment of stable isotopes in cryogenic calcites. Chemical Geology (Isotope Geoscience Section), 102, 217-228.

Clark, I. \& Lauriol, B. 1997. Aufeis of the Firth River basin, northern Yukon Canada: Insights into permafrost hydrogeology and karst. Arctic and Alpine Research. 29: $240-252$.

Clark, I. D. \& Fritz, P. 1997. Environmental Isotopes in Hydrogeology. CRC Press.

Clark, I. 2008. Groundwater Geochemistry. Course notes (C) Clark 2008.

Cogley, J. C. \& McCann, S. B. 1975. Surface runoff characteristics of an arctic nival catchment: Mecham River, Cornwallis Island. In proceedings, Canadian Hydrology Symposium - 75, Associate Committee on Hydrology, 11-14 August 1975, Winnepeg, Manitoba, 282-288.

Cooper, L. W., Olsen, C. R., Solomon, D. K., Larsen, I. L., Cook, R. B. \& Grebmeier, J. M. 1991. Stable isotopes of oxygen and natural and fallout radionuclides used for tracing runoff during snowmelt in an arctic watershed. Water Resources Research, 27, 21712179.

Craig, H. 1961. Isotopic variations in meteoric waters. Science, 133, 1702-1703.

Craig, H. \& Gordon, L. I. 1965. Deuterium and oxygen-18 variations in the ocean and marine atmosphere. Stable Isotopes in Oceanographic Studies and Paleotemperatures, Pisa, 9-130.

Crouzet, E., Hubert, P., Olive, Ph. \& Siwertz, E. 1970. Le tritium dans les measures d'hydrologie de surface. Détermination expérimentale du coefficient de ruissellement, Journal of Hydrology, 11, 217-219.

Dansgaard, W. 1954. The $\mathrm{O}^{18}$ - abundance in fresh water. Geochimica et Cosmocbimica Act, 6, 241-260. 
Dean, K. G. 1986. Regional distribution of stream icings in Alaska. Proceedings, Cold Regions Hydrology Symposium. American Water Resources Association, 339-344.

DeWalle, D. R., Swistock, B. R. \& Sharpe, W. E. 1988. Three component tracer model for stormflow on a small Appalachian forested catchment. Journal of Hydrology, 104, 301 310 .

DeWalle, D. R. \& Pionke, H. B. 1994. Streamflow generation on a small agricultural catchment during autumn recharge, II, stormflow periods. Journal of Hydrology, 163, $23-42$.

Dinçer, T., Payne, B. R., Florkowski, T., Martinec, J. and Tongiorgi, T. 1970. Snowmelt runoff from measurements of tritium and oxygen-18. Water Resources Research, 6, $110-118$.

Dingman, S. L. 1966. Characteristics of summer runoff from a small watershed in central Alaska. Water Resources Research, 2, 751-754.

Dingman, S. L. 1971. Hydrology of Glenn Creek watershed, Tanana basin, central Alaska. US Army Cold Region Research Engineering Laboratory Research Report 297, Hanover, New Hampshire.

Dingman, S. L. 2002. Physical hydrology. Prentice-Hall, Upper Saddle River, New Jersey.

Draper, N. R. \& Smith, H. 1981. Applied Regression Analysis. Wiley, New York, 709.

Drever, J. I. 2002. The Geochemistry of Natural Waters: Surface and Groundwater Environments. Third Edition. Prentice-Hall Inc. New Jersey.

Duarte, C. M. 2007. Evaluating streamflow runoff process in a Subarctic alpine catchment, Yukon Territory. Masters thesis. Carleton University, Ottawa, Ontario.

Dunne, T. \& Black, R. D. 1970. Partial area contributions to storm runoff in a small New England watershed. Water Resources Research, 6, 1296-1311.

Elsenbeer, H., Lack, A. \& Cassel, K. Chemical fingerprints of hydrological compartments and flow paths at La Cuenca, western Amazonia. Water Resources Research, 31, 30513058 .

Environment Canada. 1995. Terrestrial Ecozones of Canada. Ecological Land Classification Series. Number 19. Ottawa.

Evans, C., \& Davies, T. D. 1998. Causes of concentration/discharge hysteresis and its potential as a tool for analysis of episode hydrochemistry. Water Resources Research, 34, 129-137. 
Feng, Z., Taylor, S. \& Renshaw, C. E. 2002. Isotopic evolution of snowmelt. A physically based one-dimensional model. Water Resources Research, DOI: 10/1029/2001WR000814.

Francis, S. 1997. Data Integration and Ecological Stratification of Wolf Creek Watershed, South-Central Yukon. Report prepared for Indian \& Northern Affairs Canada and Agriculture Canada. Applied Ecosystem Management Ltd., Whitehorse: 23.

Freeze, R. A. 1974. Streamflow generation. Revolutionary Geopbysics. Space Pbysics, 12, 627-647.

Friedman, I., Redfield, A. C., Shoen, B. and Harris, J. 1964. The variation of the deuterium content of natural water in the hydrologic cycle. Revolutionary Geopbysics, 2, 177-224.

Fritz, P., Cherry, A., Weyer, K. U. \& Sklash, M. 1976. Storm runoff analyses using environmental isotopes and major ions. Interpretation of Environmental Isotope and Hydrochemical Data in Groundwater Hydrology. IAEA, Vienna, Austria, 111130.

Fritz, P. and Fontes, J. C. 1980. Handbook of Environmental Isotope Geochemistry. Volume 1. Elsevier, New York, 1-19.

Froehlich, W. and Slupik, J. 1982. River icings and fluvial activity in extreme continental climate: Khangai Mountains, Mongolia. Fourth Canadian Permafrost Conference, 26 March 1981, Calgary, Alberta. Ottawa, National Research Council of Canada, 203211.

Fulcar, G. E. 1990. Determination of the components of stormflow in streams on an urbanized and forested basin using oxygen-18. MSc. Thesis, School of Forest Resources, Pennsylvania State University, University park, 99.

Gat, J. R. 1996. Oxygen and hydrogen isotopes in the hydrological cycle. Annual Review of Earth and Planetary Science, 24, 225-262.

Gat, J. R. \& Gonfiantini, R. 1981. Stable Isotope Hydrology: Deuterium and Oxygen-18 in the Water Cycle. IAEA Technical Report Series, Vienna. Number: 210.

Genereux, D. P., Hemond, H. F. \& Mulholland, P. J. 1993. Use of radon-222 and calcium as tracers in a three-end-member mixing model for streamflow generation on the West Fork of Walker Branch watershed. Journal of Hydrology, 142, 167-211.

Genereux, D. P. 1998. Quantifying uncertainty in tracer-based hydrograph separations. Water Resources Research, 34, 915-919.

Gibson J.J., Edwards T.W.D., \& Prowse T.D. 1993. Runoff generation in a high boreal wetland in northern Canada. Nordic Hydrology, 24, 213-224.

Gibson, J. J. \& Prowse, T. D. 2000. Isobalance Special Issue. Hydrological Processes, 14, 1341 1536. 
Gibson, J. J., Price, J. S., Aravena, R., Fitzgerald, D. F. \& Maloney, D. 2000. Runoff generation in a hypermaritime bog-forested upland. Hydrological Processes, 14, 2711 2730 .

Gibson, J. J., Edwards, T. W. D., Birks, S. J., St Amour, N. A., Buhay, W. M., McEachern, P., Wolfe, B. B., \& Peters, D. L. 2005. Progress in isotope tracer hydrology in Canada. Hydrological Processes, 19, 303-327.

Godsey, S. E., Kirchner, J. W. \& Clow, D. W. 2009. Concentration-discharge relationships reflect chemostatic characteristics of US catchments. Hydrological Processes, 23, 18441864.

Grigoriev, V. Yu. \& Sokolov, B. L. 1994. Northern hydrology in the former Soviet Union. Northern Hydrology: International Perspectives, Prowse T. D., Ommanney C. S. L. and Watson L. E (editors), NHRI Science Report Number 3, 147-179.

Grey, B. J. \& MacKay, D. K. 1977. Aufeis (overflow ice) in rivers. Unpublished Progress Report for Working Group on Hydraulics of Ice-Covered Rivers. Associate Committee on Hydrology and Associate Committee on Geotechnical Research. Glaciology Division, Water Resources Branch, Inland Waters Directorate, Environment Canada.

Hall, D. K. 1980. Mineral precipitation in North Slope river icings. Arctic, 33, 343-348.

Hall, D. K. \& Roswell, C. 1981. The origin of water feeding icings on the eastern north slope of Alaska. Polar Record, 20, 433-438.

Harden, D., Barnes, P. \& Reimnitz, E. 1977. Distribution and character of naleds in northeastern Alaska. Artic. 30, $28-40$.

Harris, S. A., van Everdingen, R. O. \& Pollard, W. H. 1983. The Dempster Highway: Dawson to Eagle Plain, in Guidebook to Permafrost and Rlated Featrues of the Northern Yukon Territory and Mackenzie Delta, Canada. University of Alaska Fairbanks, 65-86.

Hazlett, P. W., Semkin, R. G. \& Beall, F. D. 2001. Hydrological pathways during snowmelt in first-order stream basins at the TLW. Ecosystems, 4, 527-535.

Heginbottom, J. A., Dubreuil, M. A. \& Harker, P. T. 1995. Canada-Permafrost (1:7 500 000 scale). The National Atlas of Canada, $5^{\text {th }}$ edition. Ottawa: National Resources Canada, sheet MCR 4177.

Heron, R. \& Woo, M. K. 1978. Snowmelt computations for a high arctic site. In proceedings, $35^{\text {th }}$ Annual Eastern Snow Conference, 2-3 February 1978, Hanover, New Hampshire, 162-172. 
Herrmann, A., Martinec, J. \& Stichler, W. 1978. Study of snowmelt-runoff components using isotopic measurements. Proceedings of Modeling of Snow Cover Runoff, USA CRREL Special Report, 79-36, 288-296.

Herrmann, A., Koll, J., Schöniger, M. \& Stichler, W. 1987. A runoff formation concept to model water pathways in forested basins. IAHS Publication 167, 251-263.

Hinton, M. J., Schiff, S. L. \& English, M. C. 1994. Examining the contributions of glacial till water to storm runoff using two- and three-component hydrograph separations. Water Resources Research, 30, 983-993.

Hinzman, L. D., Kane, D. L. \& Woo, M. K. 2005. Permafrost hydrology. In Encyclopedia of Hydrological Sciences Edited by M.G. Anderson. John Wiley \& Sons, Ltd, 1-15.

Hoeg, S., Uhlenbrook, S., \& Leibundgut, C. 2000. Hydrograph separation in a mountainous catchment - combining hydrochemical and isotopic tracers. Hydrological Processes, 14, 1199-1216.

Holecek, G. R. \& Vosahlo, M. V. 1975. Water balance of three high arctic river regimes. Proceedings, Canadian Hydrology Symposium - 75, Associate Committee on Hydrology, 11-14 August 1975, Winnipeg, Manitoba, 448-461.

Holmgren, B., Benson, C. S. \& Weller, O. 1974. Aufeis as observed by ERTS. Contract report to National Aeronautics and Space Administration, University of Alaska Geophysical Institute, 69-82.

Hooper, R.P., N. Christophersen, and N.E. Peters. 1990. Modelling streamwater chemistry as a mixture of soil-water end members: An application to the Panola Mountain watershed, Georgia, USA. Journal of Hydrology, 116, 321-343.

Hooper, R. P. 2003. Diagnostic tools for mixing models of stream water chemistry. $W$ ater Resources Research, 39.

Hooper, R. P., \& Shoemaker, C. A. 1986. A comparison of chemical and isotopic hydrograph separations. Water Resources Research, 22, 1444-1454.

Hooper, R. P., Christophersen, N., \& Peters, N. E. 1990. Modelling streamwater chemistry as a mixture of soilwater end-members - An application to the Panola Mountain Catchment, Georgia, U.S.A. Journal of Hydrology, 116, 321-343.

Hopkins, D. M. 1967. The Cenozoic history of Beringia - a synthesis. The Bering Land Bridge. Stanford, California: Stanford University Press, 451-484.

Horton, R. E. 1933. The role of infiltration in the hydrologic cycle. Transactions American Geophysical Union, 14, 446-460.

Hooper, R.P. and Shoemaker, C.A. 1986. A comparison of chemical and isotope hydrograph separations. Water Resources Research, 22: 1444-1454. 
Hu, X. \& Pollard, W. H. 1997. The hydrologic analysis and modelling of river icing growth, North Fork Pass, Yukon Territory. Canada Permafrost and Periglacial Processes. 8, 279-294.

Ingraham, N. L. \& Taylor, B. E. 1989. The effect of snowmelt on the hydrogen isotope ratios of creek discharge in Surprise Valley, California. Journal of Hydrology, 106, 233244.

Jame, Y. W. \& Norum, D. I. 1980. Heat and mass transfer in a freezing unsaturated porous medium. Water Resources Research, 16, 811-819.

James, A. L. \& Roulet, N. T. 2006. Investigating the applicability of end-member mixing analysis (EMMA) across scale: A study of eight small, nested catchments in a temperate forested watershed. Water Resources Research, 42, W08434.

Janowicz, J.R. 1991. Regionalization of low flows in Yukon Territory. Northern Hydrology: Selected Perspectives, edited by T.D. Prowse and C.S.L. Ommanney, NHRI Symposium No. 6, Saskatoon, Saskatchewan, 141-150.

Johnson, N. M., Likens, G. E., Bormann, F. H., Fisher, D. W. \& Pierce, R. S. 1969. A working model for the variation in streamwater chemistry at the Hubbard Brook Experimental Forest, New Hampshire. Water Resources Research, 5, 1353-1363.

Kane, D. L. \& Slaughter, C. W. 1972. Seasonal regime and hydrological significance of stream icings in central Alaska. International Symposia on the Role of Snow and Ice in Hydrology, Symposium on Properties and Processes, Banff, Alberta, 15.

Kane, D. L. 1981. Physical mechanics of aufeis growth. Canadian Journal of Civil Engineering, 8, 186-195.

Kane, D. L., Hinzman, L. D., Everett, K. R. \& Benson, C. S. 1989. Hydrology of Imnavait Creek, an arctic watershed. Holartc Ecology, 12, 262-269.

Kane, D. L., Hinzman, L. D., Benson, C. S. \& Liston, G. E. 1991. Snow hydrology of a headwater arctic basin, physical measurements and process studies. $W$ ater Resources Research, 27, 1099-1109.

Kendall, C., Sklash, M. G. \& Bullen, T. D. 1995. Isotope tracers of water and solute sources in catchments. Solute Modelling in Catchment Systems. John Wiley \& Sons.

Kendall, C. \& McDonnel, J. J. 1998. Isotope Tracers in Catchment Hydrology. Elsevier Science, Amsterdam.

Kirchner, J. W. 2003. A double paradox in catchment hydrology and geochemistry. Hydrological Processes, 17, 871-874. 
Ladouche, B., Probst, A., Viville, D., Idir, S., Baque, D., Lobet, M., Probst, J. \& Bariac, T. 2001. Isotope separation using isotopic, chemical, and hydrological approaches, Strengbach catchment, France. Journal of Hydrology, 242, 255-274.

Langmuir, D. 1997. Aqueous Environmental Geochemistry. Pretice-Hall Inc. New Jersey.

Laudon, H., Hemond, H. F., Krouse, R., \& Bishop, K. H. 2002. Oxygen 18 fractionation during snowmelt: Implications for spring flood hydrograph separation. Water Resources Research, 38, 1258.

Laudon, H., Seibert, J., Kohler, S., \& Bishop, K. 2004. Hydrological flow paths during snowmelt: Congruence between hydrometric measurements and oxygen 18 in meltwater, soil water, and runoff. Water Resources Research, 40, 1-9.

Lauriol, B., Cinq Mars, J. \& Clark, I. D. 1991. Les naleds du nord Yukon: Localisation, genèse et fonte. Permafrost and Periglacial Processes, 2, 225-236.

Lawrence, J. R. 1987. Use of contrasting D/H rations of snows and groundwaters of Eastern New York State in watershed evaluation. Water Resources Research, 23, 519521.

Leffingwell, E. 1919. The Canning River region, northern Alaska. U.S. Geological Survey, Professional Paper 109.

Lepisto, A. 1995. Runoff generation processes in peaty forest catchments - possibilities for regionalization. Tracer Technologies for Hydrological Systms, IAHS Publication 229, 285-294.

Lewkowicz, A.G. \& Ednie, M. 2004. Probability mapping of mountain permafrost using the BTS method, Wolf Creek, Yukon Territory, Canada, Permafrost and Periglacial Processes, 15, 67-80.

Lewkowicz, A.G. \& Young, K.L. 1990. Hydrological processes in a small catchment containing a perennial snowbank, Melville Island, N.W.T. Northern Hydrology Selected Perspectives. NHRI Symposium 6, 237-251.

Liestøl, O. 1977. Pingos, springs, and permafrost in Spitsbergen. Aarb. Nor. Polarinst, 7-29.

Linsley, R. K.\& Franzini, J. B. 1964. Water Resources Engineering. McGraw-Hill Book Company, New York, 40.

Liu, F., Williams, M. W., \& Caine, N. 2004. Source waters and flow paths in an alpine catchment, Colorado Front Range, United States. Water Resources Research, 40, W09401.

MacLean, R., Oswood, M.W., Irons III, John G. \& McDowell, W.H. 1999. The effect of permafrost on stream biogeochemistry: A case study of two streams in the Alaskan (U.S.A.) taiga. Biogeochemistry, 47, 239-267. 
Maloszewski, P. \& Zuber, A. 1992. On the calibration and validation of mathematical models for the interpretation of tracer experiments in groundwater. Advances in $W$ ater Resources, 15, 47-62.

Marsh, P., Rouse, W. R. \& Woo, M. K. 1981. Evaporation at a high arctic site. Journal of Applied Meterology, 20, 713-716.

Martinec, J., Siegenthaler, U., Oeschger, H. \& Tongiorgi, E. 1974. New insights into the runoff mechanisms by environmental isotopes. Proceedings of the IAEA Symposium on Isotope Technology and Groundwater Hydrology, 1, 129-144.

Martinec, J., Moser, H., de Quervain, M. R., Rauert, W. \& Stichler, W. 1977. Assessment of processes in the snowpack by parallel deuterium, tritium and oxygen-18 sampling. Isotopes and Impurities in Snow and Ice. LAHS-AISH publication 118, 220-231.

Maule, C.P. \& Stein, J. 1990. Hydrologic flow path definition and partitioning of spring meltwater. Water Resources Research, 26, 2959-2970.

McCartney, S. E., Carey, S. K. \& Pomeroy, J. W. 2006. Intra-basin variability of snowmelt water balance calculations in a subarctic catchment. Hydrological Processes, 20, 1001-1016.

McDonnell, J., Bonell, M., Stewart, M. K. \& Pearce, A. J. 1990. Deuterium variations in storm rainfall: Implications for stream hydrograph separation. Water Resources Research, 26, 455-458.

McDonnell, J., Stewart, M. K. \& Owens, I. F. 1991. Effect of catchment-scale subsurface mixing on stream isotopic response. Water Resources Research, 27, 3065-3073,

McNamara, J. P., Kane, D. L. \& Hinzman, L. D. 1997. Hydrograph separations in an Artic watershed using mixing model and graphical techniques. Water Resources Research, 33, 1707-1719.

McNamara, J. P., Kane, D. L. \& Hinzman, L. D. 1998. An analysis of streamflow hydrology in the Kuparuk River Basin, Arctic Alaska: a nested watershed approach. Journal of Hydrology, 206, 39-57.

Merot, P., Bourguet, M. \& le Leuch, M. 1981. Analyse d'une crue à l'aide du traçage naturel par l'oxygène 18 mesuré dans les pluies, le sol, le ruisseau. Catena, 8, 69-81.

Metcalfe, R. A. \& Buttle, J. M. 1999. Semi-distributed water balance dynamics in a small boreal forest basin. Journal of Hydrolgoy, 226, 66-87.

Metcalfe, R. A. \& Buttle, J. M. 2001. Soil partitioning and surface store controls on spring runoff from boreal forest peatland basin in north-central Manitoba, Canada. Hydrological Processes, 15, 2305-2324. 
Monteith, S. S., Buttle, J. M., Hazlett, P. W., Beall, F. D., Semkin, R. G. \& Jeffries, D. S. 2006. Paired-basin comparison of hydrological response in harvested and undisturbed hardwood forests during snowmelt in central Ontario: I. Streamflow, groundwater and flowpath behaviour. Hydrological Processes, 20, 1095-1116.

Mook, W. 2000. Environmental Isotopes in the Hydrological Cycle. IHP-V Technical Documents in Hydrology Number 39. UNESCO/IAEA: Paris/Vienna.

Mook, W. G., Groeneveld, D. J., Brown, A. E. \& Van Gansurjk, A. J. 1974. Analysis of a runoff hydrograph by means of natural oxygen-18. Proceedings of the Symposium on Isotope Techniques in Groundwater Hydrology, 1, IAEA, Vienna, Austria, 145153.

Moore, R. D. 1983. On the use of bulk aerodynamic formulae over melting snow. Nordic Hydrology, 14, 193-206.

Moore, R. D. 1989. Tracing runoff sources with deuterium and O-18 during spring melt in a headwater catchment, southern Laurentians, Quebec. Journal of Hydrology, 112, 135148.

Mougout, C. M., \& Smith, C. A. S. 1994. Soil Survey of the Whitehorse Area. Vol. 1, Takhini Valley. Research Branch, Agriculture and Agri-Food Canada. Whitehorse, (unpublished manuscript), 56.

Mulholland, P. J. 1993. Hydrometric and stream chemistry evidence of three storm flowpaths in Walker Branch watershed. Journal of Hydrology, 151, 291-316.

Newbury, R. W. 1974. River hydrology in permafrost areas. Permafrost Hydrology. Workshop Proceedings. Canadian National Committee, National Hydrological Decade. Environment Canada, 31-37.

Newbury, R. W., Beaty, K. G., Dalton, J. A. \& McCullough, G. K. 1979. Preliminary comparison of runoff relationships and water budgets in three experimental lakes basins in the continental, sub-Arctic and Arctic climatic regions of the Precambrian Shield. In proceedings of the Canadian Hydrology Symposium 79, Cold Climate Hydrology, 10-11 May 1979, Vancouver, British Columbia, 516-535.

Nikitina, N. M. \& Tolstikhin, O. N. 1973. On vertical distribution of naleds in mountains of eastern Yakutia. Siberial Naleds, Cold Regions Research and Engineering Laboratory, Draft Translation 399, 59-65.

Nolan, K. M. \& Hill, B. R. 1990. Storm runoff generation in the Permanente Creek drainage basin, west central California: An example of flood-wave effects on runoff composition. Journal of Hydrology, 113, 343-367.

Obradovic, M.M. \& Sklash, M.G. 1986. An isotopic and geochemical study of snowmelt runoff in a small arctic watershed. Hydrological Processes, 1, 15-30. 
Ogunkoya, O.O. \& Jenkins, A. 1991. Analysis of runoff pathways and flow contributions using deuterium and stream chemistry. Hydrological Processes, 5, 271-282.

Ohmura, A. 1982. Evaporation from the surface of the arctic tundra on Axel Heiberg Island. Water Resources Research, 18, 291-300.

Pearce, A. J., Stewart, M. K. \& Sklash, M. G. 1986. Storm runoff generation in humid headwater catchments: Where does the water come from? Water Resources Research, 22, $1263-1272$.

Peters, N. E., Ratcliffe, E. B. \& Tranter, M. 1998. Tracing solute mobility at the Panola Mountain Research Watershed, Georgia, USA: variations in $\mathrm{Na}^{+}, \mathrm{Cl}^{-}$and $\mathrm{H}_{4} \mathrm{SiO}_{4}$ concentrations. Hydrology, Water Resources and Ecology in Headwaters. IAHS Publication Number 248, 483-490.

Petrone, K. C., Jones, J. B., Hinzman, L. D. \& Boone, R. D. 2006. Seasonal export of carbon, nitrogen, and major solutes from Alaskan catchments with discontinuous permafrost. Journal of Geopbysical Research, 111, G02020.

Péwé, T. L. 1973. Permafrost conference in Siberia. Geotimes, 18, 23-26.

Pinder, G. F., \& Jones, J. F. 1969. Determination of the ground-water component of peak discharge from the chemistry of total runoff. Water Resources Research, 5, 438- 445.

Pionke, H. B., Hoover, J. R., Schnabel, R. R., Gburek, W. J., Urban, J. B. \& Rogowski, A. S. 1988. Chemical-hydrologic interactions in the near-stream zone. Water Resources Research, 24, 1101-1110.

Pollard, W. H. \& Van Everdingen, R. O. 1992. Formation of seasonal ice bodies. Dixon, J. C. and Abrahams, A. D. (editors), Periglacial Geomorphology, Wiley, 281-304.

Pollard, W. H. 2005. Icing processes associated with high Arctic perennial springs, Axel Heiberg Island, Nunavut, Canada. Permafrost Periglacial Processes, 16, 51-68.

Pomeroy, J. W. \& Granger, R. J. 1999. Wolf Creek Research Basin: Hydrology, Ecology, Environment. Environment Canada, Saskatoon, 160.

Pomeroy, J. W., Toth, B., Granger, R. J., Hedstrom, N. R. \& Essery, R. L. H. 2003. Variation in surface energetics during snowmelt in a Subarctic mountain catchment. Journal of Hydrometeorolgy, 4, 702-719.

Priestley, C. H. B. \& Taylor, R. J. 1972. On the assessment of surface heat flux and evaporation using large scale parameters. Monthly Weather Review, 100, 81-92.

Price, A. J. \& Dunne, T. 1976. Energy balance computations on snowmelt in a subarctic area. Water Resources Research, 12, 686-694. 
Quinton, W. L. \& Marsh, P. 1998. The influence of mineral earth hummocks on subsurface drainage in the continuous permafrost zone. Permafrost and Periglacial Processes, 9, 213228.

Quinton, W. L., Shirazi, T., Carey, S. K. \& Pomeroy, J.W. 2005. Soil water storage and active-layer development in a sub-alpine tundra hillslope, southern Yukon Territory, Canada. Permafrost and Periglacial Processes, 16, 369-382.

Quinton, W. L., Bemrose, R. K., Zhang, Y. \& Carey, S. K. 2009. The influence of spatial variability in snowmelt and active layer thaw on hillslope drainage for an alpine tundra hillslope. Hydrological Processes, 23, 2628-2639.

Reedyk, S., Woo, M. \& Prowse, T. D. 1995. Contribution of icing ablation to streamflow in a discontinuous permafrost area. Canadian Journal of Earth Sizence, 32, 13-20.

Rice, K.C. \& Hornburger, G.M. 1998. Comparison of hydrochemical tracers to estimate source contributions to peak flow in a small, forested, headwater catchment. Water Resources Research, 34, 1755-1766.

Rodgers, P., Soulsby, C. \& Waldron, S. 2004. Stable isotope tracers as diagnostic tools in upscaling flow path understanding and residence time estimates in a mountainous mesoscale catchment. Hydrological Processes, DOI: 10.1002/hyp.5677.

Rodhe, A. 1981. Spring flood: meltwater or groundwater? Nordic Hydrology, 12, 21-30.

Rodhe, A. 1987a. The origin of streamwater traced by oxygen-18. PhD Thesis. Department of Physical Geography, Division of Hydrology, Uppsala University, Uppsala, Sweden.

Rodhe, A. 1987b. Groundwater contribution to stream flow in Swedish forested till soil as estimated by oxygen-18. Isotope Hydrology, Proceedings of the IAEA Symposium, Vienna, Austria, 55-66.

Rodhe, A. 1998. Snowmelt-dominated systems. Isotope tracers in catchment hydrology Edited by C. Kendall and J.J. McDonnell. Elsevier Science B.V., The Netherlands, $391-433$.

Rostad, H. P. W., Kozak, L. M. \& Acton, D. F. 1997. Soil Survey and Land Evaluation of the Yukon Territory. Saskatchewan Institute of Pedology, Publication 5174, 495.

Roulet, N. T. \& Woo, M. K. 1986. Wetland and lake evaporation in the low Arctic. Artic and alpine research, 18, 195-200.

Rouse, W. R., Mills, P. F. \& Stewart, R. B. 1977. Evaporation in high latitudes. Water Resources Research, 13, 909-914.

Rudavin, V. V. \& Federov, A. M. 1973. Concerning naleds in eastern part of Siberian platform. Siberian Naleds, Cold Regions Research and Engineering Laboratory, Draft Translation 399, 79-87. 
Russel, M., Marsh, P. \& Onclin, C. 2005. A continuous dye injection system for estimating discharge in snow-choked streams. Aritic, Antarctic and Alpine Research., 36, 539-554.

Santeford, H. S. 1979. Snow soil interactions in interior Alaska. Proceedings Modeling of Snow Cover Runoff. Cold Regions Research and Engineering Laboratory. Hanover, New Hampshire, 311-318.

Shanely, J. B., Kendall, C., Albert, M. R. \& Hardy, J. P. 1995. Chemical and isotopic evolution of a layered eastern U.S. snowpack and its relation to stream-water compostion. Biogeochemistry of Seasonally Snow-Covered Catchments. IAHS Publication 228, 329-338.

Shanley, J. B., Kendall, C., Smith, T. E., Wolock, D. M. \& McDonnell, J. J. 2002. Controls on old and new water contributions to stream flow at some nested catchments in Vermont, USA. Hydrological Processes, 16, 598-609.

Sheppard, M. I., Kay, B. D. \& Loch, J. P. G. 1978. Development and testing of a computer model for heat and mass flow in freezing soil. In proceedings, Third International Conference on Permafrost, 10-13 July 1978, Edmonton, Alberta, Volume 1, 75-81.

Shumskii, P. A. 1964. Principles of Structural Glaciology. Dover, New York.

Sklash, M. G. 1990. Environmental studies of storm and snowmelt generation. Process Studies in Hillslope Hydrology, 401-435.

Sklash, M. G. \& Farvolden, R. N. 1976. A conceptual model of watershed response to rainfall, developed through the use of oxygen-18 as a natural tracer. Canadian Journal of Earth Science, 13, 271-283.

Sklash, M. G. \& Farvolden, R. N. 1979. The role of groundwater in storm runoff. Journal of Hydrology, 43, 45-66.

Sklash, M. G., Stewart, M. K. \& Pearce, A. J. 1986. Storm runoff generation in humid headwater catchments. A case study of hillslope and low-order stream response. Water Resources Research, 22, 1273-1282.

Slaughter, C. W. 1982. Occurrence of and recurrence of aufeis in an upland taiga catchment, in Roger J.E. Brown Memorial Volume - Proceedings of the $4^{\text {th }}$ Canadian Permafrost Conference, Ottawa, Ontario, 182-188.

Slaughter, C. W., Hilgert, J. W. \& Culp, E. H. 1983. Summer streamflow and sediment yield from discontinuous-permafrost headwaters catchments. Permafrost, Fourth International Conference, Proceedings, 17-22 July 1983, Fairbanks, Alaska, National Academy Press, Washington, D.C., 1172-1177.

Slaughter, C. W. \& Kane, D. L. 1979. Hydrologic role of shallow organic soils in cold climates. In proceedings of the Canadian Hydrology Symposium: 79 - Cold Climate 
Hydrology, Associate Committee on Hydrology, National Research Council, Vancouver, 380-389.

Sloan, C. E., Zenone, C. \& Mayo, L. R. 1975. Icings along the trans-Alaska pipeline route.

U. S. Geological Survey, Open File Report 75-87, Anchorage, Alaska, 39.

Spence, C. \& Woo, M. 2003. Hydrology of subarctic Canadian shield: Soil-filled valleys, Journal of Hydrology, 279, 151-166.

Sokolov, B. L. 1978. Regime of naleds. In Permafrost: the USSR contribution to the Second International Conference. National Academy of Sciences, Washington D. C., 408411.

Soulsby, C., Rodgers, P.J., Petry, J., Hannah, D.M., Malcolm, I.A., \& Dunn, S.M. 2004. Using tracers to upscale flow path understanding in mesoscale mountainous catchments: Two examples from Scotland. Journal of Hydrology, 291, 174-196.

Stewart, R. B. \& Rouse, W. R. 1977. Substantiation of the Priestly and Taylor parameter $\alpha=$ 1.26 for potential evaporation in high latitudes. Journal of Applied Meteorology, 16, 649650 .

Stichler, W., Rauert, W. \& Martinec, J. 1981. Environmental isotope studies of an alpine snowpack. Nordic Hydrology, 12, 297-308.

Stickler, W., Herrmann, A. \& Rau, R. G. 1986. Snowmelt runoff modeling considering environmental isotopes and conventional methods, Budapest. IAHS Publication 155, 231-244.

Swistock, B. R., DeWalle, D. R. \& Sharpe, W. E. 1989. Sources of acidic stormflow in an Appalachian headwater stream. Water Resources Research, 25, 2139-2147.

Taylor, S., Feng, Z., Kirchner, J., Osterhuber, R., Klaue, B. \& Renshaw, C. 2001. Isotopic evolution of a seasonal snowpack and its melt. Water Resources Research, 37, 759769 .

Taylor, S., Feng, Z. \& Renshaw, C. E. 2002. Isotopic evolution in snowmelt. Verification and parameterization of a one-dimentional model using laboratory experiments. Water Resources Research, DOI: 10.1029/2001WR000815.

Tolstikhin, N. I. \& Tolstikhin, O. N. 1976. Groundwater and surface water in the permafrost region. (Translation), Inland Waters Directorate, Tecbnical Bulletin, Ottawa, $97,22$.

Turner, J., Macpherson, D. K. \& Stokes, R. A. 1987. The mechanisms of catchment flow processes using natural variations in deuterium and oxygen-18. Journal of Hydrology, 94, 143-162. 
Uhlenbrook, S., Frey, M., Leibundgut, C., \& Maloszewski, P. 2002. Hydrograph separations in a mesoscale mountainous basin at event and seasonal timescales. Water Resources Research, 38, 1-14.

Uhlenbrook, S. \& Hoeg, S. 2003. Quantifying uncertainties in tracer-based hydrograph separations: A case study for two-, three-, and five-component hydrograph separations in a mountainous catchment, Hydrological Processes, 17, 431-453.

U.S. Forest Service. 1961. Soil moisture as a source of base flow from steep mountain watersheds. J. D. Hewlett, Research Paper SE 132, 11.

Van Everdingen, R. O. 1982. Management of groundwater discharge for the solution of icing problems in the Yukon. In Proceedings, $4^{\text {th }}$ Canadian Permafrost Conference, National Research Council of Canada, Ottawa, Ontario, 212-226.

Van Everdingen, R. O. \& Allen, H. 1983. Ground movements and dendrogeomorphology in a small icing area of the Alaska Highway, Yukon, Canada. Permafrost: Fourth International Conference, Proceedings, July 17-22, 1983, University of Alaska, Fairbanks, Alaska. Washington D.C. National Academy Press, 1292-1297.

Van Everdingen, R. O. 1987. Management of groundwater discharge for the solution of icing problems in the Yukon. Proceedings, Fourth Canadian Permafrost Conference, National Research Council of Canada, Ottawa, Ontario, 212-226.

Van Everdingen, R. O. 1988. Perennial discharge of subpermafrost groundwater in two small drainage basins, Yukon, Canada. Kaare Senneset (editor), Permafrost: Fifth International Conference, Proceedings, August 2-5, 1988, Trondheim, Norway. Trondheim: Tapir, 639-643.

Veillette, J. J. \& Thomas, R. D. 1979. Icings and seepage in frozen glaciofluvial deposits, District of Keewatin, N.W.T. Canadian Geotechnical Journal, 16, 789-798.

Waddington, J. M., Roulet, N. T. and Hill, A. R. 1993. Runoff mechanisms in a forested groundwater discharge wetland. Journal of Hydrology, 147, 37-60.

Wankiewicz, A. 1984. Analysis of winter heat flow in an ice-covered Arctic stream. CanadianJournal of Civil Engineering, 11, 430-443.

Wedel, J. H., Thorne, G. A. \& Baracos, P. E. 1977. The hydrology of a small catchment on Bathurst Island. Preliminary report ESCOM Report AI-17. Environmental-Social Committee, Northern Pipelines, Indian and Northern Affairs, Ottawa, Ontario, 122.

Wels, C., Cornett, R. J. \& Lazerte, B. D. 1991. Hydrograph separation: a comparison of geochemical and isotopic tracers. Journal of Hydrology, 122, 253-274.

Wels, C., Taylor, C. H. \& Cornett, R. J. 1991. Streamflow generation in a headwater basin on the Precambrian Shield. Hydrological Processes, 5, 185-199. 
Whitehead, P., Beck, P. \& O’Connell, E. 1981. A systems model of streamflow and water quality in the Bedford Ouse river system. Water Resources Research, 15, 1157-1171.

Williams, J. R. 1965. Groundwater in permafrost - an annotated bibliography. USGS Wat. Supply Pap, 1792.

Williams, J. R. 1970. Groundwater in permafrost regions of Alaska. U. S. Geological Survey, Professional Paper 696.

Williams, J. R. \& van Everdingen, R. O. 1975. Groundwater investigation in permafrost regions of North America: a review. $2^{\text {nd }}$ International Conference on Permafrost, North American Contribution, 435-446.

Williams, P. J. \& Smith, M. W. The Frozen Earth: Fundamentals of Geocryology. Cambridge University Press, Cambridge.

Woo, M. K. \& Sauriol, J. 1980. Channel development in snow-filled valleys, Resolute, N.W.T., Canada. Geogrfisker Annaler Series A: Physical Geography, 62, 37-56.

Woo, M. K. 1983. Basin water balance in a continuous permafrost environment. Proceedings Tenth International Permafrost Conference, Fairbanks, Alaska, 1407-1411.

Woo, M. K. 1986. Permafrost Hydrology in North America. Atmosphere-Ocean 24: 201 234.

Woo, M. K. 1990. Permafrost Hydrology. In Northern Hydrology Canadian Perspectives. Edited by T.D. Prowse and C.S.L. Ommanney. NHRI Science Report No. 1, Saskatoon, Saskatchewan, 63-76.

Woo, M. K. 1997. A guide for ground based measurement of arctic snow cover. Publication for Canadian Cryospheric Information Network, 30.

Woo, M. K. \& Young, K. L. 1997. Hydrology of a small drainage basin with polar oasis environment. Permafrost and Periglacial Processes, 8, 257-177.

Wrangle, F. P. 1841. A journey to the Northern Shores of Siberia and Along the Arctic Ocean Made in 1820-1924. Harper \& Brothers, St. Petersburg, Russia.

Wright, R. K. 1981. The water balance of a lichen tundra underlain by permafrost. McGill Subarctic Research Paper No. 33, Climatological Research Series No. 11, Centre for Northern Studies, McGill University, Montreal, Quebec, 110.

Yde, J. C. \& Knudsen, N. T. 2005. Observations of debris-rich naled associated with a major glacier surge event, Disko Island, west Greenland. Permafrost Periglacial Processes, 16, 319-325.

Yoshikawa, K., Hinzman, L. D., \& Kane, D. L. 2007. Spring and aufeis (icing) hydrology in Brooks Range, Alaska. Journal of Geophysical Research, 112, G04S43. 
Zhou, Y., Guo, D., Qiu, G., Cheng, G. \& Li, S. 2000. Geocryology in China. Cold and Arid Region Environment and Engineering Research Institute, Chinese Academy of Science, Beijing, 448. 